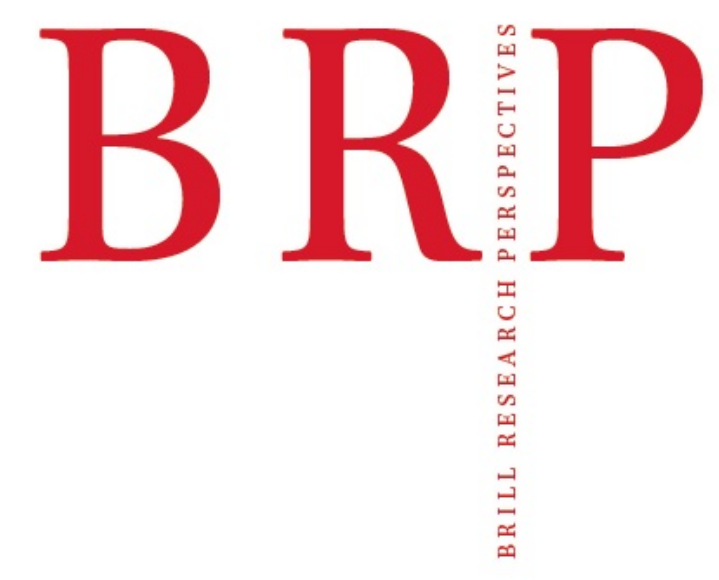

\title{
The Years of
}

Jesuit Suppression,

1773-1814: Survival,

Setbacks, and

Transformation

\begin{tabular}{l}
0 \\
0 \\
0 \\
0 \\
0 \\
0 \\
0 \\
0 \\
0 \\
0 \\
0 \\
0 \\
0 \\
\hline
\end{tabular} 
The Years of Jesuit Suppression, 1773-1814: Survival, Setbacks, and Transformation 


\title{
Brill Research Perspectives in Jesuit Studies
}

\author{
Editor \\ Robert A. Maryks (Independent Scholar)
}

Editorial Board

Ariane Boltanski (Université Rennes 2)

Carlos Eire (Yale University)

Alison Fleming (Winston-Salem State University)

Paul Grendler (University of Toronto, emeritus)

Stephen Schloesser, S.J. (Loyola University Chicago)

Volumes published in this Brill Research Perspectives title are listed at brill.com/rpjs 


\section{The Years of Jesuit Suppression, 1773-1814: Survival, Setbacks, and Transformation}

Paul Shore

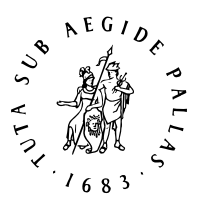

B R I L L 
This is an open access title distributed under the terms of the CC BY-NC-ND 4.0 license, which permits any non-commercial use, distribution, and reproduction in any medium, provided no alterations are made and the original author(s) and source are credited. Further information and the complete license text can be found at https://creativecommons.org/licenses/by-nc-nd/4.o/

The terms of the cc license apply only to the original material. The use of material from other sources (indicated by a reference) such as diagrams, illustrations, photos and text samples may require further permission from the respective copyright holder.

This publication is also available in Open Access at www.brill.com/rpjs thanks to generous support from the following institutions:

- College of the Holy Cross, Worcester (MA)

- Le Moyne College, Syracuse (NY)

- University of Santa Clara (CA)

This paperback book edition is simultaneously published as issue 2.1 (2020) of Brill Research Perspectives in Jesuit Studies, DOI:10.1163/25897454-12340005.

Library of Congress Control Number: 2019955223

Typeface for the Latin, Greek, and Cyrillic scripts: “Brill”. See and download: brill.com/brill-typeface.

ISBN 978-90-04-42108-0 (paperback)

ISBN 978-90-04-42337-4 (e-book)

Copyright 2020 by Paul Shore. Published by Koninklijke Brill NV, Leiden, The Netherlands.

Koninklijke Brill NV incorporates the imprints Brill, Brill Hes \& De Graaf, Brill Nijhoff, Brill Rodopi,

Brill Sense, Hotei Publishing, mentis Verlag, Verlag Ferdinand Schöningh and Wilhelm Fink Verlag.

Koninklijke Brill NV reserves the right to protect the publication against unauthorized use and to authorize dissemination by means of offprints, legitimate photocopies, microform editions, reprints, translations, and secondary information sources, such as abstracting and indexing services including databases. Requests for commercial re-use, use parts of the publication, and/or translations must be addressed to Koninklijke Brill NV.

This book is printed on acid-free paper and produced in a sustainable manner. 


\section{Contents}

The Years of Jesuit Suppression, 1773-1814: Survival, Setbacks, and Transformation 1

Paul Shore

Abstract 1

Keywords 1

1 Prelude to Dissolution 1

2 A Storm in Portugal 3

3 A Spanish Quarrel 7

$4 \quad$ Pious and Persistent Rivals 11

5 Dénouement in France 13

6 The Iberian Empires: Expulsion and Imprisonment 19

$7 \quad$ Exile, Internal and External 25

8 A Sojourn in White Russia 37

$9 \quad$ Hanging On in China 49

10 Survival in India 54

11 The British Isles 55

12 Peaceful England, Possible Bohemia $5^{8}$

13 A Legacy Not Easily Discerned 75

14 Conclusion: Rebirth, but at a Distance 77

Bibliography 93 



\title{
The Years of Jesuit Suppression, 1773-1814: Survival, Setbacks, and Transformation
}

\author{
Paul Shore \\ University of Regina, Canada, and Wolfson College, \\ Cambridge University, UK \\ shorep@brandonu.ca
}

\begin{abstract}
The forty-one years between the Society of Jesus's papal suppression in 1773 and its eventual restoration in 1814 remain controversial, with new research and interpretations continually appearing. Shore's narrative approaches these years, and the period preceding the suppression, from a new perspective that covers individuals not usually discussed in works dealing with this topic. As well as examining the contributions of former Jesuits to fields as diverse as ethnology — a term and concept pioneered by an ex-Jesuit-and library science, where Jesuits and ex-Jesuits laid the groundwork for the great advances of the nineteenth century, the essay also explores the period the exiled Society spent in the Russian Empire. It concludes with a discussion of the Society's restoration in the broader context of world history.
\end{abstract}

\section{Keywords}

China - Enlightenment - Gabriel Gruber - Niccolò Paccanari - Giuseppe Pignatelli Marquis Pombal - Jesuit suppression - Jesuit restoration - White Russia

\section{Prelude to Dissolution}

The date 1773 , like 476 and 1453 , long ago entered history books as a milestone helping define a period in world history. On July 21 of that year, the Holy See 
issued the breve Dominus ac redemptor, which suppressed the Society of Jesus. ${ }^{1}$ This development was hardly unanticipated. ${ }^{2}$ The Jesuits had been under attack, and arguably, in eclipse, for more than half a century, and the general suppression of the Society was preceded by their expulsion from the Portuguese Empire (1759), France (1762), and the Spanish Empire, including Naples and Parma, as well as Malta, still ruled by the Knights of St. John (1767). Anti-Jesuit propaganda, which had existed since the Society's creation, had grown in ferocity during the preceding decades, and the curriculum articulated in the Ratio studiorum was increasingly perceived as outdated and in particular as lacking materials reflecting recent developments in science, law, and history.

To their detractors, the Jesuits embodied all the worst qualities of the ancien régime coupled with an intolerant view of Protestants and a conniving nature that placed them at the center of many conspiracy theories. Popular writings portrayed Jesuits as secretive, deceptive, manipulative, devious regicides, intent on world domination either for themselves or for the pope. For their part, some Jesuits saw themselves the victims of vast conspiracies designed to destroy the Society. ${ }^{3}$ Simultaneously, Jesuits became convenient scapegoats for the Holy See, enabling the papacy to deflect antagonism from the papal curia to the order. Even the order's allies had begun to wonder if the Society, launched in 1540 , had a future, although at the middle of the eighteenth century twentytwo thousand Jesuits still operated nearly seven hundred colleges and two hundred seminaries worldwide. ${ }^{4}$ Yet the Jesuits were not merely unfortunate

1 I would like to thank Matthew Herrell for providing helpful editorial feedback, and George Westhaver for making Pusey House, Oxford, available as a peaceful and spiritually nurturing environment in which to work. Eric Nelson and Mário Santiago de Carvalho provided invaluable assistance in confirming biographical data. An English translation of the breve is found at "Dominus ac redemptor noster Bull of Pope Clement XIV Permanently Suppressing the Jesuit Order"; http://www.reformation.org/jesuit-suppression-bull.html (accessed June 27, 2019). The distinction between a breve (or brief) and a papal bull is significant: the former was not binding on the successors of the pontiff who issued it. H. L. R., "The Suppression of the Jesuits by Pope Clement XIV," American Catholic Quarterly Review 13, no. $5^{2}$ (1888): 696-706, here 703 .

2 Joseph II, co-regnant with his mother Maria Theresia, wrote in April of that year as if the suppression was a foregone conclusion. Franz A. J. Szabo, Kaunitz and Enlightened Absolutism 1753-1780 (Cambridge: Cambridge University Press, 1994), 244.

3 H. C. [Hans Christian] Erik Midelfort, Exorcism and Enlightenment: Johann Joseph Gassner and the Demons of Eighteenth-Century Germany (New Haven: Yale University Press, 2005), 28.

4 Dale K. Van Kley, "Jansenism and the International Suppression of the Jesuits," in The Cambridge History of Christianity, vol. 7, Enlightenment, Reawakening, and Revolution 16601815, ed. Stewart Jay Brown and Timothy Tackett (Cambridge: Cambridge University Press, 2006), 302-28, here 303 . 
targets of their opponents; they were victims of their own earlier successes, or more accurately, by their misreading of these successes. The baroque piety the Society had promoted for two centuries and the pre-encyclopedic approach to data collection that they had perfected and propagated were well suited to the mood of the seventeenth century. But at least in much of Europe, they no longer adequately addressed the Zeitgeist or needs of the eighteenth. The visual arts were moving away from the baroque and toward the calm of classicism. The floridly Latin genre of Jesuit school drama, a mainstay of the Society's educational and mission programs and a key tool of Jesuit self-representation, had declined in popularity and was banned in Vienna by $1768 .^{5}$ Other expressions of the baroque aesthetic that the Society had carried to a high level, such as thesis prints, went into decline in the years before the suppression. ${ }^{6}$

\section{$2 \quad$ A Storm in Portugal}

Yet it was not merely in the arts or education that the Society seemed, at key points, to be out of step with the times. Jesuit expressions of a sense of the holy or righteous could become flashpoints of controversy and criticism. Portugal had long been a center of Jesuit enterprise, with a collegium established in Lisbon as early as 1565 and the University of Coimbra becoming a key training ground for missionaries. But here too lay the seeds of the Society's downfall. On All Saints' Day 1755, a devastating earthquake struck Lisbon, killing thousands. The Jesuit Gabriel Malagrida (1689-1761), a veteran of twenty-eight years of missionary work in Brazil and a renowned preacher, wrote that this disaster was a divine retribution for grievous public sins, and not due merely to natural

5 James van Horn Melton, Absolutism and the Eighteenth-Century Origins of Compulsory Schooling in Prussia and Austria (Cambridge: Cambridge University Press, 1988), 81. Such developments were accompanied by a reduction in the number of religious holidays, another blow to the baroque piety promoted by the Jesuits. Between 1556 and 1773, Jesuits produced tens of thousands of tragedies, almost none of which have endured as they lacked either character development or high literary quality. The didactic and edifying function of these plays, and their cookie-cutter design, is a metaphor for much of the culture of the Society in the eighteenth century. Blair Hoxby, "The Baroque Tragedy of the Roman Jesuits: Flavia and Beyond," in Politics and Aesthetics in European Baroque and Classicist Tragedy, ed. Jan Bloemendal and Nigel Smith (Leiden: Brill, 2016), 182-218, here 182.

6 Louise Rice, "Jesuit Thesis Prints and the Festive Academic Defense at the Collegio Romano," in The Jesuits I: Cultures, Sciences, and the Arts, 1540-1773, ed. John W. O'Malley et al. (Toronto: University of Toronto Press, 1999), 148-69, here 148. 
causes. ${ }^{7}$ This pronouncement deeply angered Portuguese leaders and resulted in Jesuits being banned from the royal court. As the scandal grew, Malagrida was accused of heresy, based on fantastical theological treatises he had allegedly written, ${ }^{8}$ and on his supposed involvement in a plot to kill King José I (1714-77, r.1750-77). On September 20, 1761, the elderly Jesuit was executed in a spectacular auto-da-fé in Lisbon's Rossio Square. Two other Jesuits implicated in the alleged plot, João Alexandre (dates unknown) and João de Matos (dates unknown), died in the prison of Junqueira. ${ }^{9}$ Farther afield, the Malagrida case provoked ridicule, even from Louis XV (1710-74, r.1715-74), and inspired Voltaire (1694-1778) to write a leaflet in the voice of a Jewish rabbi supposedly outraged by the mistreatment meted out to the Jesuit. ${ }^{10}$

By then, the Jesuits had been expelled from Portugal. In 1758, an ailing Benedict XIV $\left(1675^{-1758}\right.$, r.1740-58) had issued a breve calling for an investigation of alleged Jesuit abuses: capitalizing on the death of the pontiff five weeks later, the enemies of the Society soon found the Jesuits guilty of scandalous behavior in both Portugal and its colonies. Within a month, the papal visitor, Cardinal Francisco I de Saldanha da Gama (1723-76), ordered the Jesuits to desist from all commerce, preaching, and hearing of confessions. ${ }^{11}$ The ban on commerce was not gratuitous; as we shall shortly see, Jesuit commercial activities were the root cause of an immense scandal that was just breaking in France as the papal visitor issued his pronouncement.

Later that year, King José I survived the assassination attempt in which Malagrida would be implicated (almost certainly without justification), an event that triggered gruesome public executions and the destruction of the powerful Távora family, for whom a few Jesuits had served as confessors. In 1759, on the first anniversary of the assassination attempt, the Society's property was seized by the government and many Jesuits were thrown into prison, while others were expelled: a contingent of 133 were ferried to the Papal States, an especially awkward move considering that diplomatic relations between the Holy See and Portugal had now been suspended. It took time for the edict

7 Juizo da verdadeira causa do terremoto (Lisbon: Na Officina de Manoel Soares, 1776).

8 Resposta e reflexões a carta que Clemente José Collaço Leitaõ bispo de Cochim [...] (Lisbon: Na Regia Officina Typografica, 1774), 240.

$9 \quad$ José Pedro Ferrás Gramoza, Successos de Portugal: Memorias historicas, politicas e civis (Lisbon: Typographia do Diário da Manhã, 1882), 173.

10 Sermon du rabbin Akib, sur le dernier auto-da-fe de Lisbonne (Amsterdam: Veuve J. F. Jolly, $1762)$.

11 George Edmundson, "Spain and Portugal (1746-1794)," in The Cambridge Modern History, vol. 6, The Eighteenth Century, ed. A. W. [Adolphus William] Ward et al. (Cambridge: Cambridge University Press, 1909), 361-88, here 386. 
of suppression to be carried out in all Portuguese territories: the Jesuits of Mozambique were exiled in 1759; in September of the same year, royal troops surrounded the Jesuit buildings in Goa, and almost all Jesuits were arrested. ${ }^{12}$ The Jesuits of Angola were deported to Italy on July 6, 1760, and by 1762 even Macau had conformed to Lisbon's wishes. ${ }^{13}$

The orchestrator of the responses to these events was the ambitious, welltraveled, and reform-minded Sebastião José de Carvalho e Melo, marquis of Pombal (1699-1782), but the anti-Jesuit climate that he stoked was already in place. The Society was seen as the cause of bloody uprisings by indigenous peoples against Portugal that followed the adjustment in 1750 of the boundary between Spanish and Portuguese territory in South America. ${ }^{14}$ Closer to home, Jesuits were made scapegoats for the decline of Portuguese power, an accusation with far different implications from those following from contemporaneous anti-Jesuit rhetoric in France, Austria, Poland, or the empire. The reduced status and international prestige of eighteenth-century Portugal as an imperial power had many causes, but a particularly vivid moment of remembered national "misfortune" were the sixty years from 1580 until 1640 during which the crowns of Portugal and Spain had been united. The immediate cause of this union was the death of the Jesuit-educated and advised king Sebastião I (1554-78, r.1557-78) in 1578 while conducting a "holy war" in North Africa. ${ }^{15}$ Jesuits were also blamed for moral laxity and tyrannicide, ${ }^{16}$ the latter charge easily dovetailing with the accusations swirling around the death of the young king and rumors of Jesuits arming "savages" to fight Europeans.

As was true elsewhere, Jesuit schools were seen by many as increasingly outdated; the vague sense that school reform was needed would later be sharpened

12 Mira Mascarenhas, "The Church in Eighteenth-Century Goa," in Essays in Goan History, ed. Teotónio R. de Souza (New Delhi: Concept Publishing, 1989), 81-101, here 9o. A few Jesuits may have escaped into the jungle but documentation here is lacking.

13 Geoffrey C. Gunn, First Globalization: The Eurasian Exchange, 1500 to 1800 (Lanham, MD: Rowman \& Littlefield, 2003), 109.

14 Barbara Anne Ganson, The Guarani under Spanish Rule in the Río de la Plata (Stanford: Stanford University Press, 2003), 89-93. A nearly contemporaneous account has native warriors from Jesuit reducciones attacking a Portuguese fort with artillery. Causa jesuitica de Portugal o documentos autenticos [...] [The Jesuit cause in Portugal, or authentic documents (...)] (Madrid: En la imprenta Real de la Gazeta, 1768), ix.

15 Dauril Alden, The Making of an Enterprise: The Society of Jesus in Portugal, Its Empire, and Beyond (Stanford: Stanford University Press, 1996), 657.

16 Francisco Malta Romeiras, "Jesuit Historiography in Modern Portugal," Jesuit Historiography Online, ed. Robert A. Maryks; http://referenceworks.brillonline.com/entries/jesuit -historiography-online/jesuit-historiography-in-modern-portugal-COM_192570 (accessed June 27, 2019). 
by Pombal (a member of London's Royal Society but an absolvent of no academic institution) and other Portuguese Enlightenment figures into specific indictments. A year before the worldwide suppression, a volume appeared with the sanction of the king detailing how the Jesuits had accomplished the "destruction of religion" at the famed University of Coimbra. ${ }^{17}$

Although Jesuit schools had made contributions to Portuguese culture, there was much truth in these criticisms, which had grown more vociferous over time. One Portuguese Benedictine, João Baptista de São Caetano (?-1773), went so far as to say that Jesuit education was full of darkness. ${ }^{18}$ Comments such as São Caetano's lay bare the core of the Society's problems, not only in Portugal but throughout Catholic Europe. The Benedictine order, one thousand years older than the Jesuits and long the custodian of learning in medieval Europe, was no natural ally of the Society. Yet beyond this great potential animosity between rival orders was the reality that the Jesuits' dogged commitment to Scholasticism was viewed unfavorably not merely by supporters of the Enlightenment but additionally by high-ranking members of the Catholic "establishment." Also numbered among the Society's clerical critics were the Oratorians, who put special emphasis on the natural sciences and on instruction in Portuguese..$^{19}$ There was also the problem of what the Scholastic model excluded from the field of theology (e.g., much of the speculative innovations of the most recent three centuries). Many also disliked the formulaic ways in which Jesuit Scholasticism was expressed in catechisms and apologetic works. ${ }^{20}$ And this Jesuit tendency to retain a conservative and rigid approach to theology did not exist in a vacuum. In many contexts, including Portugal, the

17 Compendio historico do estado da Universidade de Coimbra no tempo da invasão dos denominados jesuitas [...] (Lisbon: Na Regia Officina Typografica, 1772), xii.

18 Ulrich Lehner, "Introduction: The Many Faces of Catholic Enlightenment," in A Companion to the Catholic Enlightenment in Europe, ed. Ulrich Lehner and Michael Printy (Leiden: Brill, 2010), 1-61, here 30 .

19 Kenneth Maxwell, "The Spark: Pombal, the Amazon, and the Jesuits," Portuguese Studies 17 (2001): 168-83, here 169. The relationship of instruction in vernaculars (some of which, like French, were not spoken locally) to the classical program that remained the mainstay of the Jesuits was a complex one in these years: some Jesuits advocated reform in the direction of more use of the vernacular, but the image of the Society as supporting a more conservative model remained intact. An attempt to modernize the school curriculum with the introduction of the vernacular met with some success in the Habsburg lands but was not widely imitated. Instructio privata seu typus cursus annui [...] (Prague: Typis Universitatis Carlo-Ferd., 1735). Thanks to the National Library of Slovenia for access to this work.

20 Robert E. Goss, "The First Meeting of Catholic Scholasticism with dGe lugs pa Scholasticism," in Scholasticism: Cross-Cultural and Comparative Perspectives, ed. José Ignacio Cabezón (Albany: State University of New York Press, 1998), 65-9o, here 73. 
Society's near-monopoly on high-status schooling did nothing to encourage reflective self-assessment or receptivity to outside criticism, skills that might have better prepared it for the coming frontal attack. As would prove to be true elsewhere, Portuguese Jesuits lacked much sensitivity to a literary climate that favored conspiracy theories. In the end, the Jesuits of Portugal were not nearly as wily as their detractors claimed, but instead stumbled into a crisis for which they were stunningly unprepared.

\section{$3 \quad$ A Spanish Quarrel}

The downfall of the Society in Spain bore a family resemblance to Jesuit troubles in Portugal. Once again, an imperial power struggling with symptoms of decline and court intrigues played key roles, with a dramatic incident lighting the final fuse. The "Hat and Cloak" riots in March 1766 proved to be this dramatic incident. An unpopular minister of finance had hoped to reduce street crime in financially hard-hit cities by banning hats and capes that could conceal weapons and identities. The plan backfired spectacularly: Madrileños as well as residents of dozens of other towns responded to the edict by taking to the streets (wearing hats and capes) with demands that soon included reductions in the price of basic goods. A few months later, the queen mother, Elisabeth Farnese (1692-1766), a staunch supporter of the Jesuits, died. In the aftermath of the riots, Charles III's (1716-88, r.1750-88) ministers managed to convince the king that the Jesuits had been behind the unrest. Although evidence for this charge was distinctly lacking, the king, who seems to have felt himself the object of personal affronts from one Jesuit, Francisco de Rávago $\left(1685^{-1763)},{ }^{21}\right.$ and no doubt seeking a scapegoat for his realm's many problems, decreed the expulsion of the Jesuits on February 27, 1767. ${ }^{22}$ Other factors were also at play. Magnus Mörner (1924-2012) sees this dramatic step as an expression of regalismo, the assertion of royal rights at the expense of the Holy See, with the hostility of colonial bishops toward the Society playing a role. ${ }^{23}$ As in Portugal, the Society had faced critics of its aging curriculum and philosophy of education, whose deficiencies were perhaps most obvious in secondary

21 An Account of the Suppression of the Jesuits in Spain: Extracted from a Letter of Lord Holland ([London]: [S. \& R. Bentley], [between 1800 and 1899]), 2.

22 Owen Chadwick, The Popes and European Revolution (Oxford: Clarendon Press, 1981), 260.

23 Magnus Mörner, "The Expulsion of the Jesuits from Spain and Spanish America in 1767 in Light of Eighteenth-Century Regalism," Americas 23, no. 2 (1966): 156-64, here 157-58. 
education, where the Society had enjoyed a virtual monopoly. ${ }^{24}$ The prospect of seizing Jesuit assets was no doubt as attractive to the Spanish court as it was elsewhere. The Society's suppression in Spain extended to Naples and Sicily, ${ }^{25}$ with dynastic loyalties causing the Duchy of Parma to follow suit. ${ }^{26}$ The role of the Bourbon courts thus looms large in this story, but it would be a mistake to view events, as some nineteenth-century Jesuits chose to do, as simply the result of a spiteful and well-coordinated Bourbon plot. The concept of a strong ruler capable of using bureaucracies to centralize and coordinate her or his power was an emerging idea across Europe during the second half of the eighteenth century. And while the Iberian Peninsula and Italy did not experience the growth in popular book culture that occurred in the empire, anti-Jesuit publications, some completely unconnected to the regimes that sought the Society's downfall, were plentiful and widely read in the Bourbon monarchies. In Spain, rumors about Jesuit wealth and wild tales about how this wealth was transported and hidden (and enjoyed) were readily accepted as truth. One instance where considerable Jesuit wealth was confiscated occurred in Goa, where nineteen boxes of precious metals and jewels were taken from the chapel of St. Francis Xavier and sent to Portugal. However, the queen regnant Maria I (1734-1816, r.1777-1816) is said to have sent the boxes back.

For many of the devout, the baroque era of warnings of God's wrath and visionary experiences that had inspired the works that ultimately brought about Malagrida's execution was by no means over, but the climate of the Catholic Enlightenment, which now had supporters among the church hierarchy, saw little value in such things. Moreover, as Jeffrey Burson notes, for some opponents of the Society "the rhetorical skepticism that had served the apologetical pursuits of the Jesuits so well also suggested that they were conceding far too much to skeptics and heretics by appealing directly to the authority of the

24 Javier Echeverria, Andoni Ibarra, and Thomas Mormann, "The Long and Winding Road to the Philosophy of Science in Spain," in Representations of Scientific Rationality: Contemporary Formal Philosophy of Science in Spain, ed. Andoni Ibarra and Thomas Mormann (Amsterdam: Rodopi, 1997), 11-56, here 13. Dale Van Kley points out that graduates of Jesuit colleges had a virtual monopoly on high offices in the royal administration. Dale K. Van Kley, Reform Catholicism and the International Suppression of the Jesuits in Enlightenment Europe (New Haven: Yale University Press, 2018), 166.

25 Jesuit properties in the kingdom were seized on November 3, 1767. Norma Bouchard and Valerio Ferme, Italy and the Mediterranean: Words, Sounds, and Images of the Post-Cold War Era (Basingstoke: Palgrave Macmillan, 2014), 49.

26 Dale K. Van Kley, "Plots and Rumors of Plots," in The Jesuit Suppression in Global Context: Causes, Events, and Consequences, ed. Jeffrey D. Burson and Jonathan Wright (Cambridge: Cambridge University Press, 2015), 13-39, here 14. 
church for whatever could not be affirmed by individual critical reason and scholarly investigations." 27

Jesuits were thus in a no-win situation: if they took an open-minded view of worship and theology, either in Europe or abroad, they were denounced for moral laxness and indifference to Christian truth, but if they took the thundering prophetic path of Malagrida, they could be condemned as heretics. If they debated with Enlightenment skeptics, even if they occasionally seemed to win, they were wily casuists, not to be trusted. When Jesuits applied their scholarly skills to confessional polemic, they fostered a kind of skepticism about texts and sources that ultimately worked against the Society's goal of promoting unity, belief, and fidelity to the church. If they embraced the evidence of new scientific research, they were perhaps not loyal to a church that still denied Galileo Galilei's (1564-1642) achievements. And if they appealed to the authority of this same church in their arguments, they were behind the times and defenders of an oppressive institution. Their successes prompted resentment; their failures inspired their opponents. The charge sheet of alleged abuses assembled by their enemies had never been cast aside or forgotten, and the longer the Society endured, the longer the list grew.

While outright religious skepticism ${ }^{28}$ probably did not play as key a role in the downfall of the Society as has been often supposed, the Catholic Enlightenment, especially in German-speaking lands, gradually undermined the bases of lay support among many urban elites for the type of traditional piety Jesuits had long presented to the masses. ${ }^{29} \mathrm{~A}$ handful of Jesuits, perhaps most notably the editors of the Journaux de Trévoux, attempted a dialogue with the Enlightenment, but these were the exception in a Society that only very slowly adopted its school curriculum to the expanding body of knowledge and

27 Jeffrey Burson, "Distinctive Contours of Jesuit Enlightenment in France," in Exploring Jesuit Distinctiveness: Interdisciplinary Perspectives on Ways of Proceeding within the Society of Jesus, ed. Robert A. Maryks (Leiden: Brill, 2016), 212-34, here 234.

28 The mid-eighteenth century in Europe has often been characterized as a period of growth in irreligion generally. Such claims cannot be easily quantified, but neither can they be dismissed out of hand. Jansenists, the historic enemies of the Society, were fond of claiming that it was the Jesuits themselves who had opened "la route aux partisans d'irreligion" (the path to those who reject religion); Jonathan Israel, Democratic Enlightenment: Philosophy, Revolution, and Human Rights 1750-1790 (Oxford: Oxford University Press, 2011), 77. See also Dale K. Van Kley, The Jansenists and the Expulsion of the Jesuits from France, 1757-1765 (New Haven: Yale University Press, 1975).

29 Michael Printy, "Catholic Enlightenment and Reform Catholicism in the Holy Roman Empire," in Lehner and Printy, Companion to the Catholic Enlightenment, 165-213, here $192-94$. 
did not share the Enlightenment's optimistic view of human potential. ${ }^{30}$ The ongoing battles between the editors of the Journaux de Trévoux and those of the Encyclopédie reflected competing ideologies but also exposed fundamental differences between Jesuits and the philosophes on matters ranging from how knowledge should be organized to the reasons for presenting knowledge. The shift to the model of knowledge presentation embodied in the Encyclopédie placed new stress on the presentation of individual units of knowledge, and not on the interrelation of all things by means of metaphor and revelation, a classic position of baroque Jesuits. Perhaps even more importantly, the notion of human progress implied in the Encyclopédie was very different from the moral universe set forth by the sons of Ignatius.

This shift had profound consequences and might be compared in significance to the shift in the presentation of knowledge that has accompanied the development of the internet in our own day. In this debate, the Jesuits may have won some arguments on paper, but ultimately were defeated in the public sphere as much by their inability to address the conceptual challenges posed by the new model as by any specific inadequacies in their arguments. Many Jesuits endeavored to have a foot in both the philosophical and theological realms, but this was becoming increasingly difficult, if not impossible. Not surprisingly, the Encyclopédie's treatment of the Society was scathing, and widely read, including, it has been claimed, by some bishops. ${ }^{31}$ Adding to the mix was the case of Claude-François-Xavier Millot (1726-85), a professor of rhetoric in Lyon, who in 1757 produced an Éloge de Montesquieu (Eulogy on Montesquieu), which was denounced by his Jesuit superiors. Millot left the Society and went on to have a brilliant career as a historian, being elected to the Académie in $1777 .^{32}$ Anyone inclined to see the Jesuits as enemies of progress need look no further than Millot's story.

30 The Journal de Trévoux, which continued publication until 1782, acknowledged the importance of empiricism but took an anti-Cartesian position and was equally hostile to Spinozan philosophy and to the emerging analytical mathematics of the day. J. B. [John Bennett] Shank, The Newton Wars and the Beginning of the French Enlightenment (Chicago: University of Chicago Press, 2008), 196.

31 Mark A. Waddell, "Encyclopedias," in The Cambridge Encyclopedia of the Jesuits, ed. Thomas Worcester (Cambridge: Cambridge University Press, 2017), 282-83. Archbishop Basilio Santa Justa y Sancho de Rufina (1728-87), who oversaw the expulsion of the Jesuits from the Philippines, has been described by a Jesuit historian as a "Voltarian" whose views had been shaped by the encyclopédistes. Thomas B. Cannon, "History of the Jesuits in the Philippines: A Brief Sketch” [part 1], Woodstock Letters 66, no. 3 (1937): 364-86, here 379.

32 Alessandro Zanconato, La dispute du fatalisme en France: 1730-1760 (Fasano: Schena Editore, 2004), 409. 
The rivalry between the Society and mendicant orders, most especially Franciscans and Dominicans, was a much older problem for the Society, stretching back to the sixteenth century. The dispute had many facets: Franciscans emphasized their poverty and humility, which was often contrasted with the intellectual pride and fondness for high position attributed to the Jesuits. The competition between these two orders thus framed could degenerate into "turf wars" in settings such as Japan, Moldavia, or Macao, ${ }^{33}$ but the conflict was far more than this, reflecting profoundly different understandings of religious life and mission.

That the Jesuits had embraced such mottos as "unus non sufficit orbis" (one world is not enough) and called themselves the Society of Jesus, a claim that could seem presumptuous, only heightened the animosity felt by other orders. The Jesuit emphasis on books and learning stood in contrast to St. Francis's (1181/82-1226) opinion that readers of books ran the risk of exposure to vice. Yet the adaptive Jesuits could also emulate Franciscan tactics and symbols, which likewise did not endear the Society to the friars. In India, Jesuits sparred with Carmelites and Capuchins as well. ${ }^{34}$

Tensions between Dominicans and Jesuits often centered on the doctrine of the Immaculate Conception. Although not proclaimed a dogma of the church until 1854, this teaching was vigorously promoted by many Jesuits (and some Franciscans) while Dominicans, who saw themselves as the scholars and theologians of the church, did not support it. ${ }^{35}$ Differences in the views of each order regarding the role of divine grace and human free will led to ongoing controversies and eventually a papal ban on either side criticizing the position of the other. The Jesuit emphasis on the discernment of spirits in one's own life was likewise a very different path from that of the Dominicans, whose fundamen-

33 Paul Varley, Japanese Culture, 4th ed. (Honolulu: University of Hawai'i Press, 200o), 166; Daniel T. Reff, "Critical Introduction," in Andrés Pérez de Ribas, History of the Triumphs of Our Holy Faith amongst the Most Barbarous and Fierce Peoples of the New World, ed. and trans. Daniel T. Reff, Maureen Ahern, and Richard K. Danford (Tucson: University of Arizona Press, 1999), 11-45, here 29; José Eugenio Borao, "Macao as the Non-entry Point to China: The Case of the Spanish Dominican Missionaries (1587-1632)," paper presented at the International Conference "Role and Status of Macao in the Propagation of Catholicism in the East," Macao, November 3-5, 2009.

34 Charles J. Borges, "Racial Tensions of the Society of Jesus in India before 1759," in Jesuits in India: In Historical Perspective, ed. Teotónio R. de Souza and Charles Borges (Macao: Instituto Cultural de Macau, 1992), 61-71, here 66.

35 Piotr Stolarski, Friars on the Frontier: Catholic Renewal and the Dominican Order in Southeastern Poland 1594-1648 (Abingdon: Routledge, 2016), 17. 
tal role is that of preacher. These theological disputes were further enflamed by struggles over the control of schools, the Society sometimes requiring a public statement of belief in the teaching of the Immaculate Conception from instructors. ${ }^{36}$ Dominicans and Jesuits had moreover followed different paths in their respective pursuits of knowledge. The Jesuits during their first century and a half had contributed significantly to scientific literature, in part because they relied heavily on mathematics, which permitted them to explore various explanations for physical phenomena in a "hypothetical" way that sought to evade charges of heresy. But this approach earned them the mistrust of others, among them many Dominicans, who wished to restrict investigation to those avenues explicitly following from Aristotelian natural philosophy. ${ }^{37}$ In a climate inflamed by charges that Jesuit casuists were tricksters employing "mental reservation" to mislead others, ${ }^{38}$ this use of mathematics further damaged the reputation of the Society in some quarters.

Along with the Augustinians, Dominicans had lost many university chairs to Jesuits, a matter that resurfaced when the heads of both orders began to press Pope Clement XIV (1705-74, r.1769-74) to sign the breve of suppression. Some Dominicans had also accused Jesuits of moral laxity in pastoral matters, a charge echoed by Jansenists. The mood of at least some Dominicans was suggested by the celebratory banquet held in a Dominican house the night after the execution of Malagrida. As the Society's fortunes in Spain declined, the general of the Augustinians, Francisco Xavier Vázquez (1703-85, in office 1753-85), paid close attention, and played a role in the negotiations that culminated in the expulsion of the Jesuits from that kingdom. ${ }^{39}$ As soon as the Jesuits were expelled from the Spanish Empire, Mexican Dominicans openly accused the Society of heretical errors, a charge that had circulated for years. ${ }^{40}$ The Oratorians, first established in Portugal, were not as powerful as the Dominicans, but they too were rivals of the Society in settings as far off as Vietnam, and were sympathetic to Jansenism. ${ }^{41}$

36 Ivana Čornejová, "Správní a institucionální vývoj pražské univerzity (Vztah univerzity k panovníkovi, správním a zemským orgánům)," in Dějiny Univerzity Karlovy II, 1622-1802, ed. Karel Beránek et al. (Prague: Univerzita Karlova, 1996), 23-56, here 37.

Richard G. Olson, Science and Religion, 1450-19oo: From Copernicus to Darwin (Westport: Greenwood Press, 2004), 65-72.

38 Steven Shapin, A Social History of Truth: Civility and Science in Seventeenth-Century England (Chicago: University of Chicago Press, 1994), 96.

39 Richard Herr, The Eighteenth-Century Revolution in Spain (Princeton: Princeton University Press, 1958), 23.

$40 \quad$ Karen Melvin, Building Colonial Cities of God:Mendicant Orders and Urban Culture in New Spain (Stanford: Stanford University Press, 2012), 132.

41 Charles A Bolton, Church Reform in 18th-Century Italy (the Synod of Pistoia 1786) (The Hague: Martinus Nijhoff, 1969), 5; George E. Dutton, A Vietnamese Moses: Philiphê Binh 
When the opposition of a scattering of diocesan bishops, who had long resented the patterns of loyalty and obedience found in the Society, was added to this mix, the Jesuits found themselves engaged in unceasing defensive and polemical struggles, not against enemies of the church but against powerful elements of the church itself. These conflicts drew resources away from the Society's major projects, but, more importantly, fostered a siege mentality that further hampered Jesuit efforts to anticipate and deal with threats to their order. Stuck in a reactive posture, by the 176 os the Society had less energy or will to support the most creative of its members-or perhaps to attract the most intellectually ambitious to the order as well.

Dénouement in France

Disaster had meanwhile struck the Society in France. As is often the case, a specific and spectacular scandal allowed criticisms that had accumulated in a variety of contexts to be aired once more and focused on a particular target. Antoine de La Valette (1708-67) was the superior of the Society's Martinique missions. ${ }^{42}$ La Vallette was accused of engaging in commerce, which violated canon law, and was summoned to Paris for trial. It emerged that La Vallette, confronted with losses on the high seas resulting from the hostilities of the Seven Years' War (1756-63), had tried to recoup his losses by engaging in various unsuccessful (and ethically dubious) ventures without the permission of his superiors. He had then borrowed sums to cover losses that eventually reached the figure of 2,400,00o livres, a vast amount of money at the time. ${ }^{43}$ The Society was held responsible for this debt by the French courts, which effectively bankrupted the Jesuits in France and led directly to the Society's expulsion a year later.

The wider implications of the La Vallette affair stretched beyond the financial. The French Parlement, which was La Vallette's last venue of appeal, decreed that the Jesuits were harmful to the Catholic Church and to French

and the Geographies of Early Modern Catholicism (Berkeley: University of California Press, 2017), 107 .

42 D. G. [Gillian] Thompson, "The LaVallette Affair and the Jesuit Superiors," French History 10, no. 2 (1996): 206-39. When the British seized Martinique in 1762, the Jesuits were permitted to sell these properties for more than a million pounds. A Note, in Addition to That of 1845: On the Jesuits' Estates [...] (Quebec: Fréchette et Frères, 1847), 17.

43 This sum equaled roughly 25,800 ounces of gold. A workman's annual wage was typically no more than the equivalent of five ounces of gold. Some sources put the total owed by La Vallette at close to twice this sum. 
society in general. ${ }^{44}$ Such charges would soon be applied to the Society more globally, and it seems likely that the Parlement, which included many Jansenists, saw the La Vallette case as a golden opportunity to strike a mortal blow at the Jesuits. Why the Society chose to appeal La Vallette's case to this Parlement, when the court in Marseille had ruled in favor of the Jesuits' creditors, remains a mystery. ${ }^{45}$ The animosity toward the Jesuits in many parts of French society was hardly a secret. The attempted assassination of Louis XV in 1757, although it could not be tied to the Jesuits beyond the fact that the wouldbe assassin had worked as a domestic servant in a Jesuit house, had stirred up (or uncovered) intense and longstanding hostility toward the Society. The trials following the attempted assassination of the Portuguese king José I in $175^{8}$ only reinforced the old notion of Jesuits as regicides. ${ }^{46}$

Perhaps the debacle of the La Vallette case is an instance when the stereotype of the overly arrogant and self-assured Jesuit holds some truth. Perhaps, too, the La Vallette affair was the inevitable slipup in the operations of a vast, worldwide organization for which the Society's enemies had been waiting so long. If so, the anti-Jesuits were not disappointed, as the scandal and its aftermath was the biggest single disaster to face the beleaguered Society and sealed its fate, not merely in France, but throughout the world. Later scandals into which the Jesuits were drawn, such as the struggle between the Estates of Brittany and the duke of Aiguillon only accelerated the energies set in motion by l'affaire La Vallette. ${ }^{47}$ Other factors not directly involving the Society added to a climate hostile to such articulate and visible members of the Catholic Church. Voltaire's 1762 campaign for toleration in the wake of the Calas case did not focus on the Jesuits, but his indictment of the church, and by implication, all who defended it, was clear. Today, we might say that an anti-Jesuit mood in France was "trending."48

44 Karin Vélez, "Jesuits: Expulsion," in Iberia and the Americas: Culture, Politics, and History, ed. John Michael Francis (Santa Barbara: ABC-CLIO, 2006), 1:607-10, here 6og.

45 Howard Clive Bernard, The French Tradition in Education: Ramus to Mme. Necker de Saussure (Cambridge: Cambridge University Press, 1922), 222-23.

46 As early as 1595 , a Jesuit, Jean Guignard (dates unknown), had been executed for possessing writings on regicide. Eric Nelson, The Jesuits and the Monarchy: Catholic Reform and Political Authority in France (1590-1615) (n.p.: Routledge, 2017), 4. See also Van Kley's discussion of would-be regicide Jean Castel (1575-94). Van Kley, Reform Catholicism, 67.

47 D'Aiguillon was accused of grave crimes, including poisoning, and when the king intervened to protect him, the Estates were outraged. Julian Swann, Provincial Power and Absolute Monarchy: The Estates General of Burgundy 1661-179o (Cambridge: Cambridge University Press, 2003), 263.

48 S. J. Barnett, The Enlightenment and Religion: The Myths of Modernity (Oxford: Oxford University Press, 2003), 152. 
In 1763, an improbable and impermanent alliance of Jansenists and philosophes promoted by a Capuchin, Pierre Parisot, alias Norbert de Bar-le-Duc or the Abbé Platel (1697-1769), pressed for the destruction of the Society: soon, the collegia of the Jesuits throughout France were closed, and in November of the following year, the Society was dissolved in all French dominions, although some provincial parlements continued for a while to defend it. The transfer of material possessions went somewhat slowly: it was not until 1770 that the University of Paris took possession of Jesuit buildings and collections. The transfer of properties also addressed the claims of creditors: hundreds of thousands of livres from the holdings of several of the colleges were transferred to these creditors. ${ }^{49}$ The dissolution of the Society in France was a sensation discussed throughout Europe and seemed to point toward the inevitable suppression of the entire order, although what all the consequences might be for the traditional allies and patrons of the Society was far from clear.

The ambitions of monarchs and powerful ministers have long been cited as a significant factor in the downfall of the Jesuits, although in at least one instance, that of Holy Roman Emperor Joseph II (1741-90, r.1765-90), the alleged hostility of a monarch to the Society was not nearly as great as had been supposed..$^{50}$ Among the political figures openly hostile to the Jesuits, the Portuguese marquis of Pombal was arguably the most influential. Pombal saw the Jesuits as the greatest single obstacle to his plans for the drawing of power to the royal court and to himself personally, but the consequences of his anti-Jesuit campaign reached far beyond Lisbon. Through the promotion of books and pamphlets hostile to the Society, Pombal contributed to a burgeoning anti-Jesuit literature that both hastened the Society's expulsion from the Portuguese Empire and added to the legend of the evil Jesuit that endured long after the Society was restored. ${ }^{51}$ In the Spanish court, anti-Jesuit figures such Count Aranda $(1718-78)^{52}$ exercised great influence over the king, Charles III, who in his decree expelling the Jesuits proclaimed that the topic was not to

49 Charles R. Bailey, "French Secondary Education, 1763-1790: The Secularization of ExJesuit Collèges," Transactions of the American Philosophical Society 68, no. 6 (1978): 1-124, here 12.

50 Derek Beales, “The False Joseph II," Historical Journal 18 (1975): 467-95.

51 Jonathan Wright, "Pombal, Marquis," in Worcester, Cambridge Encyclopedia of the Jesuits, 627-68. Among the more preposterous claims made in the anti-Jesuit documents promoted by Pombal was the tale of the Jesuit who planned to make himself king of Paraguay and then march to São Paolo, where he would be crowned "emperor of the Mamelukes." Ernesto Ennes, "Teresa Margarida da Silva e Orta, a Brazilian Collaborator in the AntiJesuit Propaganda of Pombal," Americas 2, no. 4 (1946): 423-30, here 427. The Jesuits would not return to Portugal until 1829, and after five years were exiled again. 
be discussed, on pain of death. ${ }^{53}$ In Naples, Bernardo Tanucci (1698-1783) was fiercely anti-Jesuit ${ }^{54}$ and supported the reduction in power of all religious orders. Anti-Jesuit sentiment in the Venetian Republic ${ }^{55}$ dated back more than two hundred years, and the Society had been expelled for fifty years in the seventeenth century. Louis XV was no enemy of the Jesuits, but ultimately endorsed their abolition "for the sake of the peace of my kingdom." Rulers and courtiers throughout Europe watched the rising storm from the sidelines and made their plans accordingly.

The personality and political situation of the pontiff who issued the breve, Clement XIV, likewise played a role in events, although it is doubtful that any pope would have been able to resist indefinitely Bourbon pressure to suppress the Society. The French foreign minister, the duke of Choiseul (1719-85, in office 1758-61 and 1766-70), was even said to have observed that if Clement XIV's pro-Jesuit predecessor, Clement XIII (1693-1769, r.1758-69), had lived another decade, a schism might have resulted.

The question of the Society's future had dominated the conclave that elected him, and while there is no evidence that Clement had promised before his election to suppress the Society, John W. O'Malley observes that "he could hardly have been elected without somehow communicating a readiness to do so."56 The marriage of the Habsburg archduchess Marie Antoinette (1755-93) to the Dauphin (1754-93) in 1770 potentially brought Austria into the Bourbon camp, further increasing the pressure on this non-combative pontiff. In his pre-papal career, the Jesuit-trained Clement had not shown himself to be hostile to the Society, but as ruler of an already weakened papacy he was susceptible to both threats and inducements from agents of the Bourbon courts. Yet his fondness for the Society had on occasion also been evident. Leopold von Ranke (1795-1886) describes the character of the future pope, Lorenzo Ganganelli, as "mildest and most moderate, ${ }^{n 7}$ while the Jesuit historian Sydney Smith called him "a

53 Diego Lucci, "The Suppression of the Jesuits and the Enlightenment Discourse of Jewish Emancipation: Two Parallel Historical Phenomena," in "The Tragic Couple": Encounters between Jews and Jesuits, ed. James Bernauer and Robert A. Maryks (Leiden: Brill, 2014), 87-102, here 94. See also Van Kley, Reform Catholicism, 202-7.

54 Teófanes Egido, "El siglo XVIII: Del poder a la extinción," in Los jesuitas en España y en el mundo hispánico, ed. Teófanes Egido et al. (Madrid: Fundación Carolina Centro de Estudios hispánicos e iberoamericanos/Marcial Pons, 2004), 225-78, here 254.

55 Samuel J. Miller, Portugal and Rome c.1748-1830: An Aspect of the Catholic Enlightenment (Rome: Università Gregoriana Editrice, 1978), 12.

56 John W. O'Malley, The Jesuits: A History from Ignatius to the Present (Lanham, MD: Rowman \& Littlefield, 2014), 80.

57 Leopold von Ranke, The Ecclesiastical and Political History of the Popes of Rome: During the Sixteenth and Seventeenth Centuries, trans. Sarah Austin, 2nd ed., 3 vols. (London:John Murray, 1841), 3:212. 
weak man and an opportunist." ${ }^{58}$ Both assessments may be true. Clement's death a little more than a year after the issuance of Dominus ac redemptor was attributed by some to Jesuit poisoning, ${ }^{59}$ adding more fuel to wild conspiracy theories. ${ }^{60}$

Another contributing factor in the trend toward suppression were accounts circulating of the Society's activity in Paraguay. Modern writers have sometimes understood the Paraguayan reducciones as an early example of Jesuit "social justice work" that earned the Society the enmity of neighboring colonial powers. ${ }^{61}$ However, the negative reaction to the Jesuit "Republic of Paraguay" had more to do with the threat that an independent (and armed) polity that harbored escaped slaves posed to colonial projects than it did with the in fact paternalistic way Jesuits treated the indigenous peoples who resided in the reducciones. Voltaire's lampoon of the Jesuit "Republic" in Candide (1759) was read by an audience already inclined to believe the worst about the Society's undertakings. A diary supposedly written by a Tadeo Enis (Henis) Bohemian Jesuit who had traveled to the reducciones was also employed by the Society's opponents who found evidence of abuses in Enis's account. ${ }^{62}$ Stories of strange goings-on in South America did not cease with the suppression. In 1782, rumors spread of a "picturesque madman passing himself off as a Jesuit" who was leading an insurgency in Peru. ${ }^{63}$ Tales of vast Jesuit wealth once more inspired both resentment and avarice among the Society's foes. Although the Society held extensive properties in Europe and abroad, there were no caches of gold hidden on Jesuit estates and many communities were cash poor. ${ }^{64}$ After the

$5^{8}$ Sydney Smith, The Suppression of the Society of Jesus, ed. Joseph A. Munitiz (Leominster: Gracewing, 2004), 203.

59 See, e.g., Pompeo Anichini, An Analytical and Historical View of the Catholic Religion (London: Bentley, 1826), 108.

6o Popular artwork and verses showed the Jesuits as incorrigible and implicated them in the pontiff's death. Memoirs of Scipio de Ricci, Late Bishop of Pistoia and Prato, ed. Thomas Roscoe, 2 vols. (London: Henry Colburn, 1829), 1:12.

61 William P. Kladky, "Jesuits," in Encyclopedia of the Atlantic World, 1400-19oo: Europe, Africa, and the Americas in an Age of Exploration, Trade, and Empires, ed. David Head (Santa Barbara: ABC-CLIO, 2018), 337-40, here 340.

62 The original of this diary has never been found. Paul Shore, "Universalism, Rationalism, and the Jesuits of Bohemia 1770-180o," in Progrès et violence au XVIIe siècle, ed. Valérie Cossy and Deidre Dawson (Paris: Honoré Champion, 2001), 71-83, here 82.

63 Franco Venturi, The End of the Old Regime in Europe, 1776-1789, Part I: The Great States of the West, trans. R. Burr Litchfield (Princeton: Princeton University Press, 1991), 256.

64 Yet it must also be acknowledged that in the Spanish Empire Jesuit communities collectively owned thousands of slaves who were confiscated along with the Society's other properties. Jean-Pierre Tardieu, "Los esclavos de los jesuitas del Perú en la época de la expulsión (1767)," Caravelle 81 (2003): 61-109; Nicholas P. Cushner, Jesuit Ranches and the Agrarian Development of Colonial Argentina, 1650-1767 (Albany: State University 
suppression, the Society's work in Paraguay would receive a much more positive assessment from the Protestant academic Christian Leiste (1738-1815), but this was little comfort to exiled and imprisoned ex-Jesuits. ${ }^{65}$

The catastrophe the Society faced was helped along indirectly by many other events. The victory of the British-Prussian alliance in the Seven Years' War, despite Frederick the Great's (1712-86, r.1740-86) later support for ex-Jesuits, did nothing to stabilize the Habsburg court, long a major ally of the Society. The first partition of Poland in 1772 was the beginning of the complete destruction of a polity where the Jesuits had long been respected and influential. A few months later, Victor Amadeus III (1726-96), who was married to a Spanish Bourbon princess, became king of Sardinia (r.1773-96), potentially moving another monarchy into the anti-Jesuit camp. Famines in Central Europe between 1770 and 1773 heightened social tensions ${ }^{66}$ and reduced tax revenues, tempting rulers to look for scapegoats to blame and for new sources of funds.

Interwoven with each of these factors was the reality that for two centuries the Society had been phenomenally successful, particularly in the field of schooling, and as a result was resented by many. ${ }^{67}$ Moreover, the Society had never been inclined to hide its light under a bushel and had long advertised its successes (as well as its failures, when they produced martyrs) in a way that provoked the ire of its rivals. In addition, a complex series of events that became known as the "Chinese Rites Controversy" had reached a climax more than half a century before the breve of suppression dealt a serious blow to the Society and provided its enemies with ammunition to attack Jesuit undertakings worldwide. ${ }^{68}$ Luke Clossey sees a connection between the nationalist sentiments that stoked the rites controversy and the ultimate suppression

of New York Press, 1983), 85-106. A similar story can be told of Jesuit plantations in Brazil. Stuart B. Schwartz, Sugar Plantations in the Formation of Brazilian Society: Bahia, 1550-1835 (Cambridge: Cambridge University Press, 1985), 395-97. In the two of the Society's prazos in Mozambique, fifty-two armed slaves who functioned as a de facto police force were among the properties cataloged after the expulsion of the Jesuits. Malyn Newitt, A History of Mozambique (Bloomington, IN: Indiana University Press, 1995), 235-36. See also Thomas Murphy, Jesuit Slaveholding in Maryland, 1717-1838 (New York: Routledge, 2001).

65 Galaxis Borja González, Die Jesuitische Berichterstattung über die Neue Welt (Göttingen: Vandenhoeck \& Ruprecht, 2011), 156.

66 Jerome Blum, The End of the Old Order in Rural Europe (Princeton: Princeton University Press, 1978), 222.

67 Smith, Suppression, 327.

68 The literature on the Chinese Rites Controversy is extensive; a balanced introduction is found in Ronnie Po-chia Hsia, The World of Catholic Renewal 1540-1770, 2nd ed. (Cambridge: Cambridge University Press, 2005), 214-17. Sabina Pavone points out that "it was much easier to suppress [the Society] in 1773 after having destroyed its role in 
of the Society. ${ }^{69}$ Clossey's observation reminds us that on top of all the other accusations directed at the Jesuits, questions of their national allegiance persisted. Ignatius, while not ethnically Spanish, had remained a subject of the Spanish crown, as did many of the first Jesuits, a fact that did not endear them to all Italians or French. In the Austrian province, tensions between Germanand Hungarian-speaking Jesuits had long festered, and Polish and Hungarian Jesuit missionaries had sometimes clashed in Eastern Europe. Many, but by no means all eighteenth-century Jesuits had taken an interest in the languages and literatures of their homelands, which often would earn them the respect of nineteenth-century nationalists but could place these Jesuits at odds with neighboring ethnic populations and with monarchs desiring to downplay ethnic identity. Thus an internationalist or ethnically focused orientation could be turned against the Society by its enemies.

The treatment of Jesuits working in the South American Portuguese Empire by the civil authorities following the suppression of the Society there was particularly harsh. Hundreds were imprisoned for decades or sent to Africa, an exile that few survived. The situation was complicated by the presence of Jesuits who were not subjects of the king of Portugal. At least three Jesuits of Hungarian birth were working in Brazil in 1757. One, Fáy Dávid (1721-67), died in prison, ${ }^{70}$ and the others appear to have been able to return eventually to their homeland. Some ex-Jesuits remained in Brazil after the order of expulsion was published: these were harassed, along with former students of the Jesuits and even friends of Jesuits. ${ }^{71}$ In 1760, 127 fathers and brothers were deported to Portugal. ${ }^{72}$ Many of these ended up in the Papal States. Tomás da Silva (dates unknown), a former lay brother or coadjutor temporalis, was living in Pesaro, on the Adriatic, in 1780 , where he presumably died a few years later. ${ }^{73}$

the missionary sphere." Sabina Pavone, "Banishment, Exile and Opposition: Jesuit Crises before the 176os," Lusitania sacra $3^{2}$ (2015): 105-19, here 119.

69 Luke Clossey, Salvation and Globalization in the Early Jesuit Missions (Cambridge: Cambridge University Press, 2008), 59.

70 Paul Shore, Narratives of Adversity: Jesuits in the Eastern Peripheries of the Habsburg Realms (1640-1773) (Budapest: CEU Press, 2012), 80.

71 Dauril Alden, "Late Colonial Brazil, 1750-1808," in Colonial Brazil, ed. Leslie Bethell (Cambridge: Cambridge University Press, 1987), 284-343, here 301.

72 Alden, Making of an Enterprise, 274.

73 Serafim Leite, Artes e ofícios dos jesuítas no Brasil (1549-1760) (Lisbon: Edições Brotéria, 1953), 265 . 
Also living in Pesaro was pharmacist Manuel Dinis (1708-after 1780), who had continued to ply his trade. ${ }^{74}$

The fate of ex-Jesuits in the Spanish Empire could be equally grim. Those banished from the Philippines were transported first to Acapulco, then to Veracruz, and on to Cádiz, from whence they boarded a ship to Italy, a process taking up to two years. ${ }^{75}$ Some were too weak to travel beyond Genoa on to the Papal States, while those who ended up in the snowy Apennines struggled with the change in climate. ${ }^{76}$ A primary source for the experiences of Philippine Jesuits in exile is the Arresto y viaje de los jesuitas de Filipinas (The arrest and transport of the Jesuits of the Philippines) of Francisco Javier Puig (1720-82). ${ }^{77}$ Puig retraces the protracted voyages of the sixty-eight expelled Jesuits to Italy, by way of Acapulco, adding to his account the prophecies of disasters that the expulsion of the Jesuits was supposed to trigger. ${ }^{78} \mathrm{~A}$ few ex-Jesuits managed to emerge from these ordeals, if not unscathed, then at least alive. Gottfried Bernhard von Middendorf (1741-82), who had worked on the Pacific coast of Mexico, smuggled a letter to his family out of the prison of Puerto de Santa María, Spain, with the help of Swiss guards. Eventually, he was freed through the intervention of Maria Theresia $(1717-80) .{ }^{79}$ At least one native-born Mexican Jesuit returned to his homeland before the restoration of the Society: Francisco Bernárdez (1740-1813) was ordained priest in Italy in 1770, arrived in Mexico in 1808 , and remained there until his death. ${ }^{80}$

The suppression brought forth rejoicing in many quarters and was regarded, in the words of one modern historian, by Enlightenment thinkers as the "inevitable, logical, and just consequence" of a struggle for intellectual freedom. ${ }^{81}$

74 Leite, Artes e ofícios, 161-62.

75 Leo A. Cullum, review of Philippine Jesuits in Exile by Nicholas P. Cushner, Philippine Studies 13, no. 2 (1965): 391-93.

76 Inmaculada Fernández Arrillaga, El destierro de los jesuitas castellanos (1767-1815) ([Valladolid]: Junta de Castilla y Léon, 2004), $155-56$.

77 Marta María Manchado, Consecuencias de la expulsión de los jesuitas: Filipinas (Madrid: Fundación Ignacio Larramendi, c.2005), 8; Ernest J. Burrus, A Diary of Exiled Philippine Jesuits (1769-1770) (Rome: Tip. Editrice Michele Pisani, 1951).

78 For the prophecies circulating in Italy after the suppression, see Emanuele Colombo, "Jesuit at Heart: Luigi Mozzi de' Capitani (1746-1813) between Suppression and Restoration," in Jesuit Survival and Restoration: A Global History, 1773-19oo, ed. Robert A. Maryks and Jonathan Wright (Leiden: Brill, 2015), 212-28, here 214-15.

79 Albrecht Classen, Early History of the Southwest through the Eyes of German-Speaking Jesuit Missionaries (Lanham, MD: Lexington Books, 2013), 28.

8o Francisco Zambrano and José Gutiérrez Casillas, Diccionario bio-bibliográfico de la Compañía de Jesús en México, 16 vols. (Mexico City: Editorial Jus, 1961-77), 15:324.

81 Brendan Dooley, "The Storia letteraria d'Italia and the Rehabilitation of Jesuit Science," in Jesuit Science and the Republic of Letters, ed. Mordechai Feingold (Cambridge, MA: MIT Press, 2003), 433-73, here 461. 
Jean-Baptiste le Rond d'Alembert (1717-83) hailed the suppression as "an occurrence worthy to figure among the outstanding events of an age which itself would prove a landmark in the history of the human mind." 82

At the same time, rumors abounded that the Jesuits had in fact not disbanded, but merely realigned themselves with (for example) the Masons and remained committed to their conspiracies. Johann Adam Weishaupt (17481830), who founded the Illuminati in 1776 , is sometimes described as a former Jesuit, a convenient claim given the broader context of continued Jesuit plotting. In fact, he was trained by Jesuits, and a lay professor of canon law at the University of Ingolstadt. Other supposed Jesuit conspiracies involved a plot to destroy the Bourbon dynasties, unearthed just as the Society was about to be suppressed. ${ }^{83}$ The lingering suspicion that the Jesuits had engendered is reflected in the observation of John Adams (1735-1826), made two years after the restoration of the Society: "Shall we not have regular swarms of them here, in as many disguises as only a king of the gypsies can assume [...]?"84 The story of the Society's suppression and eventual restoration must be understood in the context of this continuing suspicion and dislike, which did not dissipate in the nineteenth century and became one of the defining characteristics of the environment in which the restored Society had to function.

The suppression ushered in no victory for those of the Society's opponents whose motivations were strictly theological. The religious positions of antiJesuits gained no ground, while some of the practices promoted by Jesuits among the laity, such as devotion to the Sacred Heart, continued or even grew in popularity. Many French bishops during the La Vallette case had expressed their admiration for the Society, and there is little to suggest that these attitudes changed after 1773. Events nevertheless brought confusion and despair for Jesuits who had seen what was coming but all the same had supposed that their traditional secular patrons, in particular, the Habsburg Maria Theresia of Austria, would protect them. ${ }^{85}$ An especially profound shock awaited Jesuits

82 Paul Hazard, European Thought in the Eighteenth Century, trans. J. Lewis May (London: Hollis and May, 1954), 508.

83 Jeffrey Merrick, "Claude Amable de Cohade de La Garderie: Family Conflict and Political Conspiracy under Louis XV," Journal of Canadian History 52, no. 1 (2017): 1-28.

84 Quoted in Raymond Schroth, The American Jesuits: A History (New York: New York University Press, 2007), 57.

85 William V. Bangert, A History of the Society of Jesus (St. Louis, MO: Institute of Jesuit Sources, 1986), 397. Yet it should be remembered that unlike other major European courts, the Habsburgs did not expel the Jesuits from their lands and in most cases arranged for both priests and brothers to receive modest pensions. With the exception of those Jesuits who had held chairs of theology, most Jesuit professors in the Habsburg lands retained their positions after 1773 . 
expelled from Spain, who, after a short stay in Corsica, ${ }^{86}$ found the guns of the pope pointed at them as they approached the Papal States from the sea.

In the Western Hemisphere colonies of Spain and Portugal, about five thousand neophytes were left without pastors. ${ }^{87}$ In the Spanish colonies alone, the Society had run two hundred missions and schools, staffed by 2,606 Jesuits, that maintained contact with a quarter of a million Indigenous people. ${ }^{88}$ In Mexico, Jesuit schools had been important training grounds for Creole elites, some of whom had family ties to the Jesuits. The Society's expulsion triggered pro-Jesuit protests in several Mexican cities that were suppressed with severity. ${ }^{89}$

The vast distances separating territories ruled by Spain resulted in delays in the execution of the decree of expulsion. In Baja California, Jesuits were not forcibly removed from their posts until February 1768. Among those expelled was Johann Jakob Baegert (1717-72), an Alsatian, who returned to the Rhineland where he published (anonymously) an account in German of the Baja mission. ${ }^{90}$ Deported from his post in Sonora to a Spanish prison, Ignaz Pfefferkorn (1726-98) languished there for almost a decade until family connections enabled him to return to his homeland where he completed his study of Sonora.${ }^{91}$ These missions were given to the Franciscans, although the material properties of the Society passed under the control of military commissioners, ${ }^{92}$ a process repeated elsewhere in the Spanish Empire. ${ }^{93}$ In what is today eastern

86 D. [David] A. Brading, Church and State in Bourbon Mexico (Cambridge: Cambridge University Press, 1994), 3.

87 Marek Inglot, “Le missioni della Compagnia di Gesù di Russia Bianca," Studia missionalia 60 (2011): 319-54, here 319 .

88 Olga Merino and Linda A. Newson, "Jesuit Missions in Spanish America: The Aftermath of the Expulsion," Revista de historia de América 118 (1994): 7-32, here 7; Josep-Ignasi Saranyana et al., eds., Teología en América Latina (Madrid: Iberoamericana, 2005), 553.

89 Israel, Democratic Enlightenment, 386.

9o Nachrichten von der Amerikanischen Halbinsel Californien mit einem zweyfachen Anhand falscher Nachrichten (Mannheim: Churfürstl. Hof- und Academie-Buchdruckerey, 1773). See also Hans-Jürgen Lüsebrink, "Between Ethnology and Romantic Discourse: Martin Dobrizhoffer's History of the Apibones in a (Post)modern Perspective," in Jesuit Accounts of the Colonial Americas: Intercultural Transfers, Intellectual Disputes, and Textualities, ed. Marc André Bernier, Clorinda Donato, and Hans-Jürgen Lüsebrink (Toronto: University of Toronto Press, 2014), 127-43, here 128.

91 Beschreibung der Landschaft Sonora samt andern merkwürdigen Nachrichten von den inneren Theilen Neu-Spaniens und Reise aus Amerika bis in Deutschland [...] von Ignaz Pfefferkorn ([Cologne]: Lang, 1794).

92 Charles E. Chapman, "The Jesuits in Baja California (1697-1768)," Catholic Historical Review 6, no. 1 (1920): 46-58, here 57-58.

93 An eyewitness account of the deportation of Jesuits from La Paz is found in Wolfgang Bayer, Reise nach Peru, ed. C. G. [Christoph Gottlieb] von Murr (Nuremberg: Bey Johann Eberhard Zeh, 1776), 201-13. 
Bolivia, a system of governance largely unchanged from that maintained by the Society continued after 1768 with the principal differences being that the aboriginal people could now trade and the missions themselves were run by secular clergy. In the Philippines, where the Society had managed numerous haciendas, ex-Jesuits too ill to travel were allowed to stay, but the management of the sale of Jesuit properties was so poorly handled that there was not enough money to care for these men nor to maintain the former Jesuit churches and schools. ${ }^{94}$ Most of the former Jesuit missions in the Spanish colonies declined after the departure of the Society, a trend most pronounced where mission communities were still in the process of consolidation when the Jesuits were expelled.

The Jesuits of the remote Marianas missions were not read the order of expulsion until August 26, 1769. The aftermath of this expulsion was given an additional anti-Jesuit fillip by the investigation launched the following year into the misconduct of the deceased father Francisco Javier (Franz Xaver) Reitenberger (1707-67), who was accused of sexual offenses..$^{95}$ Despite these hardships, a few former Jesuits found roles in the Spanish Empire. Manuel Ventura Figueroa Barreiro (1708-83), who has been described as a "Gallican," became governor of the Council of Castile immediately after the publication of Dominus ac redemptor.

The announcement of the actual papal breve of suppression was thus no bolt from the blue, and the Society had already been gravely crippled by its expulsion from the majority of major European powers. The exception was of course the Habsburg realms, where despite the events of the previous fifteen years, some Jesuits in remote eastern communities were still surprised to find their order suppressed (and the breve of suppression supported unequivocally by their monarchs). The suppression of a major Catholic order with a worldwide mission was virtually without precedent ${ }^{96}$ that might be consulted as to how to proceed. Not only was the breve ignored in some countries, it was also interpreted differently in specific dioceses. In Liège, the prince-bishop allowed the Jesuits to continue their work, but with the requirement that they aban-

94 Salvador P. Escoto, "Governor Anda and the Liquidation of the Jesuit Temporalities in the Philippines, 1770-1776," Philippine Studies 23, no. 3 (1975): 293-319, here 304.

95 Archivo Histórico Nacional, Inquisición, 3730, Exp. 149, 1770; http://pares.mcu.es/ ParesBusquedas/servlets/Control_servlet?accion=3\&\&txt_tipo_busqueda=dl\&txt _busqueda=\&txt_correo=S\&txt_id_desc_ud=3741148 (accessed June 27, 2019).

96 During the previous two centuries, several much smaller Catholic orders had been suppressed. In addition, the scandal-ridden Order of Templars had been suppressed by papal bull in 1312, but the Ecumenical Council of Vienne (1311-12) never passed a definitive judgment on the case. Smith, Suppression, 291. 
don their vow of obedience: henceforth, he alone would be their superior. In England, ex-Jesuits remained at their posts and retained their properties, having first submitted to the vicar apostolic. ${ }^{97}$ In Poland, efforts were made to halt the publication of Dominus ac redemptor, but these soon failed.

In these uncharted waters, a few ex-Jesuits began to reinvent themselves. The past-suppression career of Don Raymondo Hormaza (Hormasa) (c.1750?1789?) forms a curious sidelight to the aftermath of the destruction of the Society's missions in the Spanish Empire. Hormaza's early years are obscure; he may have been born in Bilbao. After years of wandering following the Jesuits' expulsion from Spain, he arrived in Liverpool where he took the somewhat implausible pseudonym the Reverend Raymund Harris and worked in a Catholic church before falling out with the local bishop. There in 1788 Harris published a pamphlet presenting scriptural arguments in favor of the slave trade. ${ }^{98}$ Harris's efforts, which earned him a gift of $£ 100$ from the city of Liverpool, also triggered rebuttals from the pulpit and in the form of pamphlets by leading abolitionists. Harris died in 1789 , having produced no other surviving writings.

Meanwhile, support for a restored Society came from an unexpected quarter: the Protestant German poet and mystic Novalis (Georg Philipp Friedrich Freiherr von Hardenberg [1772-1801]) called for the return of the Jesuits from Russia. Johann Wolfgang von Goethe (1749-1832), normally no friend of the baroque, after seeing a play produced in 1786 that retained some of the Society's baroque touches, conceded that Jesuit churches were "distinguished by a pleasing pomp." ${ }^{99}$ And real relief came from other and unexpected quarters. Frederick the Great of Prussia refused to publish the breve of suppression, and, after a standoff lasting two years, the king and the Holy See reached an ad hoc agreement whereby Jesuits could continue their activities within Prussia, not as members of a religious order, but only as individual clergy answerable to their bishops. The king claimed to have no investment in the Society's religious goals, writing in 1774: "I view [the Jesuits] only as men of letters, whose place in the instruction of youth it would be difficult, if not impossible to supply."100

97 Thomas M. McCoog, "Libera nos Domine?' The Vicars Apostolic and the Suppressed/ Restored English Province of the Society of Jesus," in Early Modern English Catholicism: Identity, Memory, and Counter-Reformation, ed. James E. Kelly and Susan Royal (Leiden: Brill, 2017), 81-101, here 91.

98 Scriptural Researches on the Licitness of the Slave-Trade, excerpted in Thomas Clarkson and Ottobah Cugoano: Essays on the Slavery and Commerce of the Human Species, ed. Marie-Antoinette Smith (Peterborough, ON: Broadview Editions, 2010), 377-80.

99 Cited in Robert Schwickerath, Jesuit Education: Its History and Principles Viewed in the Light of Modern Educational Problems (St. Louis, MO: B. Herder, 1903), 172.

100 Cited in Schwickerath, Jesuit Education, 176. 
Old habits among the former Jesuits died hard: for a short while, the Jesuits in Frederick's Rhineland territories referred to themselves as members of the "Provincia Prussiae Occidentalis Societatis Jesu" (The western Prussian province of the Society of Jesus). ${ }^{101}$ Early in 1776, Frederick announced the dissolution of the Society within his realms, implicitly admitting that they had been functioning as more than a collection of "men of letters." ${ }^{102}$ Indeed, up until then the fathers were still known in official documents as "Jesuiten." In the place of the Society, a "Royal Schools Institute" was established, which endured until $1800 .{ }^{103}$ Under these arrangements, former Jesuits in Silesia (which until 1740 had been a Habsburg territory and part of the Austrian province of the Society) remained highly visible. Anton Michael Zeplichal (1737-1806) became director of Breslau University, ${ }^{104}$ and many other fathers continued as teachers and preachers, among them Anton Marcus Liebisch (1737-77), a "Professor der Aesthetik" (professor of aesthetics) in Breslau and author of a German grammar. ${ }^{105}$ At Frederick's death, his successor, Frederick William II (1744-97, r.1786-97), suppressed the ex-Jesuits and transferred their possessions to the universities of Halle and Frankfurt an der Oder. ${ }^{106}$ But Johann Nepomuk Köhler (1750-1836), often called the "last German Jesuit," was not ordained until 1776 and was able to work first as a gymnasium instructor, then a professor at the University of Breslau, dying in 1836.107

\section{Exile, Internal and External}

The experiences of former Jesuits varied wildly depending on their geographic and political situation. Contrasting with the pronounced hardships experienced by many Habsburg and Iberian Jesuits, the post-1773 careers of some Italian ex-Jesuits were productive and acknowledged. Francesco Antonio Zaccaria (1714-95), distinguished for his historical studies published in Italian, was appointed professor of church history at the Sapienza in Rome. Zaccaria

\footnotetext{
101 Leopold Witte, Friedrich der Große und die Jesuiten (Naumburg: Sieling, 1892), 43.

102 Zdzislaw Lec, Jezuici we Wroctawiu (1581-1776) (Wrocław: PWT, 1995), 47.

103 Chadwick, Popes and European Revolution, 397.

104 Max Lehmann, Preussen und die katholische Kirche seit 1640: Fünfter Teil; Von 1775 bis 1786 (Leipzig: Hirzel, 1885), 48.

105 Fortsetzung und Ergänzungen zu Christian Gottlieb Jöchers allgemeinem Gelehrten-Lexico [sic] [...] Dritter Band (Delmenhorst: Georg Jöntz, 1810), 1793.

106 Eduard Duller, Die Jesuiten wie sie waren und wie sie sind (Berlin: Carl Klemann, 1845), 90.

107 Norbert Conrads, ed., Die tolerierte Universität: 30o Jahre Universität Breslau 1702 bis 2002 (Wiesbaden: Franz Steiner, 2002), 241.
} 
was a member of more than a dozen learned academies and published a defense of the Council of Rome of 1725 . His Raccolta di dissertazioni di storia ecclesiastica (Collection of essays on church history) appeared in twentytwo volumes, the final tomes published posthumously. Zaccaria's successful sojourn in Rome was the result of his good relations with several popes and especially his criticism of Jansenism while supporting "sound doctrine." The prolific Zaccaria was also among the relatively few who dared to offer a detailed rebuttal (albeit anonymously) to the charges against the Society set forth by Portugal. ${ }^{108}$

Other Italian ex-Jesuits had solid, if not stellar post-1773 careers. A sixvolume text linking logic and theology by Alfonso Muzzarelli (1749-1813), who unlike Zaccaria had taught mostly lower-level grammar classes, enjoyed wide distribution, and his ascetical work Il mese di Maria o sia di Maggio (The month of Mary, or May) has gone through more than one hundred printings. ${ }^{109}$ Muzzarelli also devoted two books to refutations of the ideas of Jean-Jacques Rousseau (1712-78). Giulio Cesare Cordara (1704-85), best known today as a historian of the Society, devoted his post-suppression leisure time to a Latin burlesque work on his friendship with Ruggiero Boscovich $(1711-87)^{110}$ and to the composition of drama. Known as an "abate" (an honorific for an esteemed clergyman) and the "Principe dell'Accademia" (Prince of the academy) in his home town of Alessandria, to which he had returned after 1773, Cordara also produced memorial poetry, and even an apologia for the illfated Malagrida. ${ }^{111}$ Having become a secular priest, the Venetian Matteo Luigi Cannonici (1727-1805) built a library in his home city containing thousands of medieval manuscripts. Many of these found their way to the Bodleian Library. ${ }^{112}$ Simultaneously, Luigi Lanzi $\left(173^{2-1810}\right)$ was establishing a reputation as an authority on coins, gems, and medallions. ${ }^{113}$ Lanzi also composed a history of painting in Italy and took on the task of trying to decipher Etruscan, and

108 Raccolta d'apologie edite, ed inedite della dottrina, e condotta de' PP. Gesuiti in Risposta agli opuscoli che escono contra la Compagnia di Gesù (Venice: Antonio Zatta, 176o-61).

109 Carlos Sommervogel, ed., Bibliothèque de la Compagnie de Jésus: Nouvelle edition, 11 vols. (Brussels: Oscar Schepens, 1890-1930), 9:708-10.

110 Capitoli sulla parrucca del P. Ruggiero Boschovik [sic] e due egloghe militari (Osimo: Domenicantonio Quercetti, 1792).

111 Il buon raziocinio dimostrato in due scritti, o siano saggi critico-apologetici sul famoso processo, e tragico fine del fu p. Gabriele Malagrida (Lugano, 1794). The work is anonymous but credited by Sommervogel to Cordara.

112 "Oriental Manuscripts, Mainly Hebrew, Collected by Matteo Luigi Canonici"; https:// archiveshub.jisc.ac.uk/search/archives/cefcc137-5oe5-3441-b784-adcd718c6f57 (accessed July 1, 2019).

113 Onofrio Boni, Elogio dell'abate Don Luigi Lanzi, tratto dalle sue opera (Pisa: Presso Niccolò Capurro, 1816), 17 . 
project that remains incomplete to this day. At the time of the suppression, Girolamo Tiraboschi (1731-94) was the librarian of the duke of Modena and had published only one volume of his Istoria della letteratura italiana (History of Italian literature) but was able to produce twelve more in the coming eight years, thereby becoming the first historian of Italian literature and linking the classical and post-classical literature of the Italian peninsula. ${ }^{114}$ Tiraboschi also popularized a theory propounded two centuries earlier by Giammaria (Giovanni Maria) Barbieri (1519-74) that Provençal rhymed poetry had been influenced by Arabic, an idea that rowed against Orientalizing tendencies that would become so prominent for the next century. ${ }^{115}$ Several ex-Jesuits reported on the natural sciences, among them Giovanni Domenico Giulio (1747-1831) and Francisco Gustà (1744-1816), who described earthquakes in Calabria and Sicily. ${ }^{116}$ Carlo Borgo (1731-94) continued a Jesuit tradition of producing works on fortifications with his Analisi ed esame ragionato dell'arte della fortificazione e difesa delle Piazze (An analysis and reasoned examination of the art of fortification and the defense of city squares [Venice: Antonio Zatta, 1777]). ${ }^{117}$ In such an environment, ex-Jesuits might debate with one another. Shortly after the breve of suppression was promulgated, the Italian Giovanni Battista Roberti (1719-86) sparred with the Chilean-born Diego José Abad (1727-79) over the use of Latin by non-Italians. ${ }^{118}$ Finally, to conclude a list that might be made much longer, Carlo Francesco Gianella (1740-1810) taught mathematics at the University of Pavia and at the former Jesuit collegium in Brera, France, and wrote textbooks on mathematics. ${ }^{119}$

This parade of accomplished Italian ex-Jesuits is no grab bag of strays. The community that coalesced after 1773 revealed the degree to which the pre-suppression Society in Italy had continued to attract young men of superior ability right up until the end. The apparent absence of invective directed toward

114 Tiraboschi's critical view of Spain's impact on Italian culture was shared by other Italian ex-Jesuits but should not be seen anachronistically as "patriotic."

115 Nadia R. Altschul, Geographies of Philological Knowledge: Postcoloniality and the Transatlantic National Epic (Chicago: University of Chicago Press, 2012), 182.

116 Agustín Udías, "Jesuits' Studies of Earthquakes and Seismological Stations," Geological Society London Special Publications 310, no. 1 (2009): 135-43, here 137. Gustà, who was based in Venice after the suppression, also composed many anti-Jansenist tracts.

117 Borgo, who was also a dramatist, was granted the rank of lieutenant colonel by Frederick the Great for this work. Camille Pitollet, review of Friedrich der Grosse und die Italiener by Alessandro D'Ancona, Bulletin italien 5 (1905): 298-302, here 300.

118 Arnold J. Kerson, "Diego José Abad, Dissertatio Ludicro-seria," Humanistica Lovaniensia 40 (1991): 357-422, here 363 .

119 Sommervogel, Bibliothèque, 3:1385; Johann Christian Poggendorff, Biographischliterarisches Handwörterbuch der exakten Naturwissenschaften, 8 vols. (Leipzig: Johann Ambrosius Barth, 1863), 1:891. 
these former Jesuits as ex-Jesuits says much about the cultural climate in Italy, both at court and in the press. Yet without new recruits this community had no future. Still, while they could, many of these men forged alliances with one another supported not merely by their shared status as former Jesuits but also because of common beliefs and worldviews as well as through their commitment to inquiry. It is here that we find some of the most significant links between former Jesuits and currents of Enlightenment thought. This willingness to engage with new ideas had developed during the years before 1773 among Jesuits conducting scholarship (often presented in poetic form) largely untrammeled by confessional and polemical considerations. ${ }^{120}$ With a perhaps slightly anachronistic turn of phrase, Owen Chadwick (1916-2015) is prepared to describe the positions of some of these former Jesuits as on the "radical left." ${ }^{\prime 21}$ However labeled, the intellectual freedom exercised by ex-Jesuits in Italy would not be seen again in the history of the Society until the latter half of the twentieth century.

Exiles from the Spanish overseas empire joined these men, sometimes serving in the diocese of the Papal States or in Italian schools. ${ }^{122}$ Of the more than two hundred former Jesuits who lived in Rome in 1803, eleven alone were from Chile. ${ }^{123}$ Others worked as tutors for aristocratic families or as librarians. One of the most remarkable of these émigrés was Juan Ignacio de Molina (1740?-1829), who arrived in Bologna from Chile in 1767 . Molina had completed a manuscript on the natural and civil history of his homeland, but it was confiscated during his journey to Europe. He then reassembled the materials from memory and published the work in ${ }^{1770 .}{ }^{124}$ Forty-five years later, Molina's Analogías menos observadas de los tres reinos de la naturaleza (Minor observations on the three kingdoms of nature) would anticipate some of Charles Darwin's (1809-82)

120 Yasmin Haskell, Loyola's Bees: Ideology and Industry in Jesuit Latin Didactic Poetry (Oxford: Oxford University Press, 2003), 178.

121 Chadwick, Popes and European Revolution, 381. Chadwick cites the case of Luigi Brenna (1737-1812), a former Jesuit who published a sympathetic biography of Galileo in 1778 . See also Mario D'Addio, The Galileo Case: Trial, Science, Truth, trans. Brian Williams (Leominster: Gracewing, 2004), 153 .

122 An important manuscript source for these men is Lorenzo Hervás, Biblioteca jesuíticoespañola de los escritores que han florecido por siete lustros: Estos empiezan desde el año de 1759, principio del reinado del Augusto Rei Carlos III, y acaban en el año 1793, conserved in the Santuario de Loyola.

123 Walter Hanisch Espíndola, Itinerario y pensamiento de los jesuitas expulsos de Chile (Santiago de Chile: Andrés Bello, 1972), 149. Also living in Rome was the Mexican former lay brother Miguel Zabala, who took up the study of medicine in order to serve the poor of the city. Jacques-Augustin-Marie Crétineau-Joly, Histoire religieuse, politique et littéraire de la Compagnie de Jésus, 3rd ed., 6 vols. (Paris: Lecoffre, 1859), 5:375.

124 Louis Caruana, S.J., "The Legacies of Suppression: Jesuit Culture and Science; What Was Lost? What Was Gained?," in Burson and Wright, Jesuit Suppression, 262-77, here 269. 
theories. ${ }^{125}$ In a more backward-looking vein, Roque Menchaca (1743-1810), another exiled ex-Jesuit living in Bologna, in 1804 published the first collection of the letters of Ignatius. ${ }^{126}$ Menchaca also produced Memorias cronológicas $y$ geográficas de los arzobispados de América y Filipinas (Chronological and geographical recollections of the archbishoprics of America and the Philippines), which included references to dioceses in Canada, Missouri, and Texas. ${ }^{127}$ Juan de Velasco (1727-92), a native of Ecuador, took a position against the philosophes and endeavored, like other South American Jesuits who are sometimes called "Creole Jesuits in exile," to glorify the "New World."128 Velasco's Historia moderna del reino de Quito y crónica de la provincia de la Compañía (The recent history of the kingdom of Quito and chronical of province of the same name of the Jesuits) was completed in 1789 but a portion of it remained unpublished until 1842. Another distinguished South American historian who migrated to Italy, José Guevara (1719-1806), produced a manuscript history of Paraguay. However, like Velasco's work, it did not see the light of day for decades. ${ }^{129}$ Lastly, Juan Nuix (1740-83) articulated a defense of the conquista harkening back to the mindset of the Counter-Reformation and that attacked both Enlightenment values and capitalist exploitation of human beings. ${ }^{130}$

Spanish ex-Jesuits were welcomed to the literary debates so common in eighteenth-century Italy, mixing easily with their Italian confrères in what one historian has called "not so much a more or less secret organization as a society of learned men."131 Juan Andrés y Morell (1740-1817), who after his exit from Spain made Ferrara his headquarters, composed a history of literature that included discussions of Voltaire and Rousseau. ${ }^{132} \mathrm{~A}$ few Portuguese Jesuit scientists also settled in Italy. Eusebio da Veiga $(1718-98)$ was a notable astronomer and had taught mathematics in Lisbon. In Rome, Veiga became the rector of the

125 Analogías menos observadas de los tres reinos de la naturaleza; http://www.memoria chilena.cl/602/w3-article-70971.html (accessed July 1, 2019).

126 Epistolae Sancti Ignatii Loyolae (Bologna: Typis Gasparis de Franciscis, 1804).

127 Stafford Poole, "The New World in Papal Documents: The First Century; Review Article," Catholic Historical Review 78, no. 4 (1992): 601-6, here 6o3.

128 Adam Szászdi, "The Historiography of the Republic of Ecuador," Hispanic American Historical Review 44, no. 4 (1964): 503-50, here 509.

129 Sommervogel, Bibliothèque, 3:1923.

130 Niccolò Guasti, "Catholic Civilization and the Evil Savage: Juan Nuix Facing the Spanish Conquista of the New World," in Encountering Otherness: Diversities and Transcultural Experiences in Early Modern Europe, ed. Guido Abbatista (Trieste: Università di Trieste, 2011), 285-302.

131 Venturi, End of the Old Regime, 263.

132 Richard Herr, The Eighteenth-Century Revolution in Spain (Princeton: Princeton University Press, 1958), 82. Andrés y Morell re-entered the Society shortly after its restoration. 
Portuguese Hospital and published eight volumes of astronomical ephemera. ${ }^{133}$ The discovery of the diary of Manuel Luengo Rodríguez (1735-1816), another Spanish ex-Jesuit exiled to Italy, has shed light not only on the historical events described therein but also serves as a reminder of how great an impact the suppression had on the self-perception of former Jesuits. Members of the old Society had not written diaries (at least not openly): their identities as individuals were subsumed by the membership in the Society. Luengo Rodríguez, buffeted back and forth between his home country and Italy, experienced these events as an individual with a high degree of sensitivity to events. ${ }^{134}$

We have encountered nothing so far of the Jesuit musical tradition, but in Antonio Eximeno y Pujades (1729-1809) we find an ex-Jesuit who wrote on music during the suppression. A professor of mathematics and rhetoric in Spanish universities, a playwright, and possibly the author of two works on military subjects, ${ }^{135}$ Eximemo arrived in Rome in 1767 and undertook the study of music theory. Using the pseudonym "Aristodemo Megareo," Eximeno gained admission to many literary societies and produced a theory of musical composition based on the rules of prosody. ${ }^{136}$ Eximino's rather non-musical approach to music, and the scarcity of any notable musicians among the ex-Jesuits active after ${ }_{1773},{ }^{137}$ calls attention to the decline in Jesuit musical activity that had begun before the suppression and contrasted with earlier contributions in the baroque period. While one should not read too much into this trend, the frequently rigid and defensive posture of the Society during its years of crisis and exile does not seem to have been conducive to any of the creative arts. The Połosk academy staged concerts, but they were a far cry from the multimedia extravaganzas of a century earlier.

Christopher Storrs argues that attitudes toward the Society and toward religion more generally in the Savoyard state were "transformed"138 after 1789, when some Italians, troubled by developments in France, drew closer to the values of the ancien régime. The same might be said about other parts of Italy. But this potentially more positive view of the Society was soon to be overwhelmed

133 Johann Heinrich Mädler, Geschichte der Himmelskunde, 2 vols. (Braunschweig: George Westermann, 1873), 2:42.

134 Manuel Revuelta González, Once calas en la historia de la Compañía de Jesús: "Servir a todos en el Señor" (Madrid: Universidad Pontificia Comillas, 2006), 184.

135 Biographie universelle, ancienne et moderne, 85 vols. (Paris: Michaud, 1815), 13:565.

136 Iteatri: Giornale drammatico musicale e coreografico 3, no. 1 (1829): 273.

137 An exception was Franz Joseph Johann Nepomuk Bullinger (1744-1810), a friend of the Mozart family and violist. Ruth Halliwell, The Mozart Family: Four Lives in a Social Context (Oxford: Clarendon Press, 1998), 239.

${ }_{13} 8$ Christopher Storrs, "The Suppression of the Jesuits in the Savoyard State," in Burson and Wright, Jesuit Suppression, 138-6o, here 159. 
by external events: the "period of splendor" was about to end. The arrival in Italy, first of French Republican ideas, and then, after 1796, of the victorious armies of France, put an end to the ex-Jesuit republic of letters. The overthrow of monarchies and elites who had traditionally supported the Society, the devastation brought by war, and especially the attacks on the church turned many former Jesuits who might otherwise have continued their dialogue with the Enlightenment into outspoken opponents of the revolution and all its works. ${ }^{139}$ Insecurity and danger discouraged bold inquiry and expression. Links between the aristocracy and the Society, which had always been part of the latter's political and educational program, were reinforced, forging a bond that would greatly influence the post-1814 Society.

The paths of ex-Jesuits in France typically led to much less pleasant directions than those in Italy. Immediately after 1773 , ex-Jesuits continued to figure prominently in French political and theological debates. In 1775, during a jubilee announced by Clement XIV, sixteen former Jesuits preached in Paris against the ideas of the philosophes, with, it was claimed, considerable success. ${ }^{140}$ Two years later, four Portuguese ex-Jesuits were sent to Guyana with the pope's blessing, because the French crown needed missionaries who could speak the local language. ${ }^{141}$ In the 1770 s and 1780 s, many ex-Jesuits worked as secular diocesan priests, providing a cheap labor force for French bishops, who generally regarded these men highly. However, former Jesuits in France, who continued to number in the hundreds, faced a prolonged period of uncertainty. A number pursued completely new careers as jurists, physicians, and diplomats. ${ }^{142}$ Not surprisingly, several former Jesuits were present at the opening of the Estates General at Versailles in May of 1789. A few months later, the National Constituent Assembly suppressed all religious orders, and the status of their members remained extremely vulnerable through the period of the Terror (during which at least forty ex-Jesuits were killed). ${ }^{143} \mathrm{~A}$ few ex-Jesuits

139 Inmaculada Fernández Arrillaga and Niccolò Guasti, "The Exiled Spanish Jesuits and the Restoration of the Society of Jesus," in Maryks and Wright, Jesuit Survival, 178-96, here 183. The king of Spain, Charles IV, nonetheless wrote to Pius vi that the horrors of the revolution sprang from the "teaching and impure hands" of the Jesuits. Bangert, History, 432.

140 Crétineau-Joly, Histoire, 5:358.

141 Crétineau-Joly, Histoire, 5:356.

142 Philippe Lécrivain, "Une prosopographie des ex-jésuites 'parisiens' (1762-1848)," Mélanges de l'École française de Rome: Italie et Méditerranée modernes et contemporaines 126, no. 1 (2014); https://journals.openedition.org/mefrim/1670\#toctoin2 (accessed July 1, 2019). See also Van Kley, Reform Catholicism, 7 regarding the "criminalization" of the cause of Catholic reform.

143 Representative of this group is the Blessed Jean-François-Marie Benoît-Vourlat (1731-92). After refusing to take the oath required by the Civil Constitution of the Clergy, Vourlat's 
were initially amenable to the new Constitutional Church, but they were the exception. Michel-Joseph Dufraisse (1730-1802) accepted the post of bishop of Cher in 1798 but, recalling his vow as a Jesuit not to accept ecclesiastical dignities, resigned three years later. ${ }^{144}$

Napoleon Bonaparte's (1769-1821) Concordat with the Holy See in 1801 did nothing to resolve the question of the status of ex-Jesuits, some of whom languished in prisons or were sentenced to transportation for life. ${ }^{145}$ Pensions paid by the government to these men had long since dried up. Meanwhile, rumors of Jesuit plots abounded in a climate where "la patrie en danger" (the homeland in danger) was a watchword. What Richard Clay calls "pro-Catholic royalist murder squads"146 roamed the streams of Lyon in 1797. Their choice of name, "La Compagnie de Jéhu," was hardly accidental and surely fostered associations with the Jesuits. Meanwhile, the "father of the conspiracy theory," ex-Jesuit Augustine de Barruel (1741-1820), was about to publish the first volume of his Memoires pour servir à l'histoire du Jacobinisme (Memoirs contributing to the history of Jacobinism), which blamed the French Revolution and its excesses on Enlightenment thinkers, with shadowy Illuminati ultimately manipulating the players. ${ }^{147}$ Barruel's book, although later denounced for its "paranoid fantasies," was one of the most influential publications by a former Jesuit of the late eighteenth century, a fact not always acknowledged by later Jesuit historians.

To the south, the Jesuit presence in Malta, technically independent, but practically a fief of the Kingdom of Naples, ended on April 22, 1768: all twenty Jesuits were arrested and soon expelled. The Society's properties became the nucleus of the "Pubblica Università di Studi Generali" established by the grand-master. ${ }^{148}$ The Society did not make a permanent return to the island until ninety-nine years later.

throat was slit on September 3, 1792. Pierre-Sylvain Maréchal [?], Almanach des honnêtes gens, contenant les prophéties pour chaque mois de l'année 1793 [...] (Paris, 1793), 62.

144 Joseph F. Byrnes, Priests of the French Revolution: Saints and Renegades in a New Political Era (University Park, PA: Pennsylvania State University Press, 2014), 208-9.

145 Joseph Burnichon, La Compagnie de Jésus en France 1814-1914, 4 vols. (Paris: Beauchesne, 1914-22), 1:38.

146 Richard Clay, "The Expulsion of the Jesuits and the Treatment of Catholic Representational Objects during the French Revolution," in The Jesuits II: Cultures, Sciences, and the Arts, 1540-1773, ed. John W. O'Malley et al. (Toronto: University of Toronto Press, 2006), 691-706, here 698 .

147 Lindsay Porter, "Barruel, Abbé," in Conspiracy Theories in American History: An Encyclopedia; Volume 1, A-L, ed. Philip DiMare (Santa Barbara: ABC-CLIO, 2003), 115-16.

148 Thomas MacGill, A Hand Book or Guide, for Strangers Visiting Malta (Malta: Luigi Tonna, 1839), 65 . 
Pierre-Joseph Picot de Clorivière (1735-1820) was a relatively rare example of an ex-Jesuit who spent time in a Benedictine monastery following the suppression. Clorivière had also worked incognito in England for some years, and in 1790 established the Société du Cour de Jésus (Society of the Heart of Jesus), ${ }^{149}$ which sought to perpetuate Jesuit spirituality and was also rumored to be a vehicle for the return of "Jesuitism." At the time, former Jesuits were regarded as "suspect" by the revolutionary governments and their successors. During Napoleon's reign, Clorivière, a prolific writer of devotional tracts, was imprisoned on charges of involvement in a conspiracy against the emperor's life but survived to see the restoration.

In the empire, a few ex-Jesuits found roles to play in the continuing Catholic Enlightenment. Lorenz Hübner (1751-1807), who following the suppression took up the study of jurisprudence and then turned to journalism, sheltered under the liberal regime of Count Hieronymus Colloredo (1732-1812), prince-bishop of Salzburg. ${ }^{150}$ On the other hand, Hermann Goldhagen (1718-94), a native of Mainz, published the Religions-Journal, which took a hard line against reformist Catholic theology. ${ }^{151}$ These disagreements among former Jesuits point to less visible but real fault lines within the Society dating from before 1773, as well as to differences in the social origins and working environments of Jesuits in German-speaking lands. Notably, with the exception of Gabriel Gruber (1740-1805), no ex-Jesuits from the empire, despite their numbers, figured prominently in either the recreation of the Society in Russia or its work in the United States. ${ }^{152}$ Perhaps this was due to the relative comfort and security in which some German ex-Jesuits found themselves. The literary critic Christoph Friedrich Nicolai (1733-1811) wrote mysteriously that "what the [ex-]Jesuits are allowed in Munich, is well known," citing with approval a Düsseldorf newspaper that asserted that in "no other land in the world have

149 Simultaneously, an order for women, La Société du Coeur de Marie, was also created. André Rayez, Formes modernes de vie consacrée (Paris: Beauchesne, 1966), 187.

150 Werner Sauer, "Kant and the Principality of Salzburg," in Detours: Approaches to Immanuel Kant in Vienna, in Austria, and in Eastern Europe, ed. Violetta L. Waibel (Vienna: V \& R Unipress, 2015), 58-73, here 59-60.

151 Michael Printy, Enlightenment and the Creation of German Catholicism (Cambridge: Cambridge University Press, 2009), 135; Ulrich L. Lehner, Enlightened Monks: The German Benedictines 1740-1803 (Oxford: Oxford University Press, 2011), 93; Christopher McIntosh, The Rose Cross and the Age of Reason: Eighteenth-Century Rosicrucianism in Central Europe and Its Relation to the Enlightenment (Leiden: Brill, 2011), 20.

152 Uwe Glüsenkamp, Das Schicksal der Jesuiten aus der Oberdeutschen und den beiden rheinischen Ordensprovinzen nach ihrer Vertreibung aus den Missionsgebieten des portugiesischen und spanischen Patronats (1755-1809) (Münster: Aschendorff, 2008). 
the Jesuits since their suppression been treated better than in the Palatinate lands, especially the duchies of Jülich and Berg." ${ }^{153}$

The situation in Poland was in many ways utterly unlike that faced by former Jesuits in other European states. The commonwealth was in the process of being dismembered by its neighbors, and for twenty years after the publication of Dominus ac redemptor this crisis completely absorbed the attention and efforts of the political leadership. Since Jesuits had long championed Polish language and literature, the nationalist sentiments heightened by the prospect of the complete destruction of the republic tended to foster sympathy for rather than resentment toward the Society among many Poles. The continuing prestige of the Society and the ways in which Jesuit identity was valued is hinted at by Stanisław Załęski (1843-1908), who notes that when the suppression was imposed, scholastics, young men at the beginning of their training, and their "professeurs" "found it impossible to be happy"154 in other religious orders, and so retired to private life. The relationship between the Society and the very numerous szlachta (roughly, the gentry) in Poland was particularly close. Indeed, many Jesuits were members of the szlachta.

The identities of Catholic, Polish-speaker, member of a titled family, and Jesuit remained closely intertwined in the final years of the republic, although these connections were of less practical value in the exiled Jesuit community of Połock. Thus, when a Commission for the National Education of the Kingdom of Poland and the Grand Duchy of Lithuania (Polish: Komisja Edukacji Narodowej, abbreviated KEN) was formed in October 1773, its reformist agenda was not so much pitted against Jesuit educational practices as it was promoted by the almost three hundred former Jesuits who initially served on the commission in various capacities. ${ }^{155}$ After 1773 , the educational system in Volhynia and Right-Bank Ukraine was administered by the KEN, which transferred control of some Jesuit schools to the Basilians. In Lviv, now in Habsburg territory, the Jesuit university was reconstituted as a state academy. Many Polish Jesuits found posts as chaplains to noble families while two eventually became bishops. ${ }^{156}$ During the same period, Polish ex-Jesuits were particularly

\footnotetext{
153 Friedrich Nicolai, Beschreibung einer Reise durch Deutschland und die Schweiz im Jahre 1781, 12 vols. (Berlin: [Selbstverl.], 1781-96), 7:63. Author's translation.

154 Stanisław Załęski, Les jésuites de la Russie-Blanche, trans. Alexandre Vivier, 2 vols. (Paris: Letouzey et Ané, [1886?]), 1:72.

155 Beata Topij-Stempińska, "Jezuici i Komisja Edukacji Narodowej w polskiej historiografii XX wieku i początkach XXI wieku," Biblioteka wspótczesnej myśli pedagogicznej 3 (2014): 409-18.

156 Richard Butterwick, "Catholicism and Enlightenment in Poland-Lithuania," in Lehner and Printy, Companion, 297-358, here 330.
} 
prominent in astronomy. Marcin Poczobut-Odlanicki (1728-1810) had studied in Italy and France and was elected a member of the Royal Society of London before the suppression. Poczobut became rector of the University of Vilnius, where he had conducted astronomical observations, in 1780, a post he held for twenty-seven years. ${ }^{157}$

Yet this was not the whole story: the eastern half of the commonwealth was predominantly Lithuanian-speaking, and the Jesuit connection to that language was far less developed than to Polish. More than one thousand Jesuits worked in the Society's Lithuanian province in 1773 , but probably a majority of these spoke only Polish. 158 This region was under mostly Russian control by 1795 . By this time, natural attrition had reduced the total number of former Jesuits still active as educators to about fifty for the entire region originally within the republic. ${ }^{159}$ The newly minted Jesuits of the Połock community did not replenish these numbers, nor was the re-establishment of a Jesuit presence in a now dismembered Poland the most pressing concern of those in Rome who dreamed of the restoration of the Society. The years of suppression thus saw the irreversible collapse of Jesuit influence in north central Europe, and the disappearance of the "Jesuit teacher" as a feature of those societies. Yet the positive view held by many of the work of the Society endured.

Polish ex-Jesuits were particularly drawn to journalism, which meant communication in the vernacular. Stefan Odrowąż Łuskina (1725-93) published the Gazeta Warszawska (Warsaw gazette), which lasted until 1791 and in 1776 offered its readers a summary of the American Declaration of Independence. ${ }^{160}$ Łuskina had been an astronomer and professor of mathematics and did a short

157 Agustín Udías, Searching the Heavens and the Earth: The History of Jesuit Observatories (Dordrecht: Kluwer, 2003), 32; Richard Butterwick, The Polish Revolution and the Catholic Church, 1788-1792: A Political History (Oxford: Oxford University Press, 2012), 218.

${ }_{15} 8$ A Lithuanian historian asserts that in the years before 1773, an "ever decreasing number of Jesuit priests" knew Lithuanian. William R. Schmalstieg, review of Petras Jonikas, Lietuviu kalba ir tauta amžių būryje: Visuomeniniai lietuvių kalbos istorijos bruožai (The Lithuanian language and nation through the ages: Outline of a history of Lithuanian in its social context), Lituanaus 34, no. 4 (1989); http://www.lituanus.org/1989/89_4_06.htm (accessed July 1, 2019).

159 John A. Račkauskas, "The Commission for National Education in Poland and Lithuania (1773-1794): A Historical Study of Some Aspects of Its Educational Reforms" (PhD diss., University of Ottawa, 1977), 223, Pro Quest UMI Microform DC53279.

16o Larry Wolff, "The Spirit of 1776: Polish and Dalmatian Declarations of Philosophical Independence," in History of the Literary Cultures of East-Central Europe: Junctures and Disjunctures in the 19th and 2oth Centuries, ed. Marcel Cornis-Pope and John Neubauer (Amsterdam: John Benjamins, 2004), 1:294-306, here 295. 
stint in France as the confessor of the Polish king Stanisław August Poniatowski (1732-98, r.1764-95) during the latter's visit to France in 1765 .

Piotr Świtkowski (1744?-93), like Łuskina, a mathematician by training, published the monthly Pamiętnik polityczny $i$ historyczny przypadków (Historico-political memoir), which took a more sympathetic view of reform. ${ }^{161}$ A member of KEN, Świtkowski supported freedom of the press and religion and admired the Josephinian reforms in neighboring Austria. The translator and historian Jan Chrzciciel Albertrandi (1731-1808) was one of several Polish ex-Jesuits who became bishops, and before the suppression he too had edited a publication, which had been launched in Vilnius and bore the memorable name Zabawy przyjemne i pożyteczne (Pleasant and useful delightful amusements). Later, another former Jesuit who became a bishop, Adam Naruszewicz (1733-96), was briefly editor. ${ }^{162}$ As time passed, and ex-Jesuits died or retired, the direct influence of the old Society on Polish public life waned, but its immediate impact on the doomed commonwealth was great. Still an overwhelmingly rural society with few urban centers and insufficient resources to establish a new university, Poland-Lithuania turned to its former Jesuits as an ad hoc intellectual community that had no rivals (although Piarist teachers succeeded the Jesuits in many secondary schools). This community had a special interest in national history and language (Naruszewicz was the author of an influential history of Poland). In each of these respects, Poland resembled Hungary, but there were important differences as well. The number and prominence of Polish ex-Jesuits was even greater than in Hungary, virtually all former Jesuits active in Poland were ethnic Poles, whereas ex-Jesuits in Hungary came from various ethnicities, and the tensions created by the Society's promotion of a Transylvanian Uniate Church were absent. Other ex-Jesuits continued in roles that were more characteristic of the old Society. Tomasz Grodzicki (1718-1802) conducted an urban ministry on Warsaw and wrote a catechism. ${ }^{163}$ Antoni Janiszewski (1728?-after 1781), working in Lviv, which had passed under Habsburg control, published volume after volume of his sermons. ${ }^{164}$

\footnotetext{
161 Daniel Stone, The Polish-Lithuanian State, 1386-1795 (Seattle: University of Washington Press, 2001), 316.

162 Neomisia Rutkowska, Bishop Adam Naruszewicz and His History of the Polish Nation: A Critical Study (Washington, DC: Catholic University of America Press, 1941), 30.

163 Józef Pelczar, Zarys dziejów kaznodziejstwa w Kościele Katolickim (Kraków: Spółka Wydawnicza Polska, 1896), 2:289.

164 Pelczar, Zarys, 290.
} 
Jesuits had been visiting Russia for two centuries, and in the time of Peter the Great (1672-1725, r.1682-1725) at least one member of the Moscow aristocracy had joined the Society, ${ }^{165}$ but these encounters had not always been positive. The Orthodox hierarchy deeply mistrusted the fathers, and Jesuits returned the compliment, calling them "the most primitive of men."166 But Catherine (1729-96, r.1762-96), like Frederick, saw the value in allowing the Jesuits to continue their work in her realm, especially since they could promote loyalty to her among the Polish Catholic nobility. ${ }^{167}$ Dominus ac redemptor was therefore not to be published in the Russian Empire. On January 13, 1774, the empress had issued an ukase (decree) commanding the Jesuits residing in her territories to alter nothing of their way of life or work. At the same time, she warned them to obey all of the laws of the empire or lose their privileges. The rise of Catherine's favorite, Prince Potemkin (1739-91), after 1782, provided the exiled Jesuits with another ally of great influence and power, ${ }^{168}$ but as these men would learn, their status within Russia was entirely dependent on the attitude of the sovereign, which could change at any moment.

With the first partition of Poland in 1772, 201 Jesuits of the province of Mazovia came under Russian rule. Some of these traveled eastward to White Russia (modern-day Belarus) when the suppression took effect. The Jesuit collegium in Połock, which had been founded in 1580, was also in Russia after the first partition of Poland. The school remained open with Jesuit instructors still at their work, many of whom continued with the dress, rule, and name of the old Society. ${ }^{169}$ Over time, others joined them. Ex-Jesuits who had served in neighboring Lithuania and Mazovia were granted papal permission to rejoin the Russian Society.

Others came from farther away. Antoni Lustig (1752-1815) hailed from Prussia and came to the region in 1776 , eventually becoming provincial of White Russia. ${ }^{170}$ Gaetano Angiolini (1748-1816), a native of Piacenza, arrived

\footnotetext{
165 Anton V. Florovskij, "Pervy Iezuit iz moskovskikh dvoryan," Acta Academiae Velehradensis 19 (1948): 249-56.

166 Anton V. Florovskij, Ceštíjesuité na Rusi:Jesuité ceské provincie a slovensky vychod (Prague: Vyšehrad, 1941), 256.

167 Daniel Schlafly, "True to the Ratio studiorum?: Jesuit Colleges in St. Petersburg," History of Education Quarterly 37, no. 4 (1997): 421-34, here 424.

168 Załęski, Jésuites de la Russie-Blanche, 1:378.

169 Chadwick, Popes and European Revolution, 388.

170 Inglot, "Missioni," 340. This essay will use the then-current term "White Russia" rather than the name Belarus.
} 
in 1783, painted frescos in the interior of the Catholic church of Vitebsk, served as chancellor of the collegium, and stayed until about 1801 when he migrated to St. Petersburg. ${ }^{171}$ Jean-Nicolas Beauregard (1733 or 1731-1804) was from Metz and after a career combatting the philosophes had fled to London from the Terror. ${ }^{172}$ The presence of these men from distant lands may have been seen by the Russian monarchy as a positive good, since the reduction of Polish national sentiment among the local gentry was one of St. Petersburg's goals for the region. ${ }^{173}$ But the sudden influx of men of many backgrounds also produced strains for a community that was endeavoring to build a cohesive identity. There were also occasional problems with men who joined the community from Poland, and the canonical irregularity of the entire project.

A larger problem loomed over the entire undertaking, which James T. Flynn describes succinctly: "The Jesuits were in almost constant conflict with the Archbishop of White Russia, Stanisław Siestrzencewicz-Bohusz, the head of the [Catholic] Church in the Russian Empire, who wanted, at bottom, to control every facet of the life of the church in Russia, in close collaboration with the government."174

Conflicts between Jesuits and the local ordinary were as old as the Society; what made this collision more dangerous were the position of Catholicism as a tiny minority within Russia, and the Russian tradition of secular control over ecclesiastical policy. Stanisław Siestrzeńcewicz-Bohusz (1731-1826) accepted this tradition without protest and was known for his critical view of the papacy. The tsarina had badgered Pius VI (1717-99, r.1775-99) to accept an ex post facto arrangement by which Siestrzeńcewicz-Bohusz had been made an archbishop, a post he held for the next four decades. It is perhaps noteworthy that the archbishop, while like Catherine not an ethnic Russian, was like his imperial mistress an outspoken Russophile. His coadjutor as bishop (also titular bishop of Gadara in partibus $)^{175}$ was the Polish former Jesuit Jan Benisławski

171 "Language-Learning in the 18th-Century Russian Empire"; http://quellen-perspectivia .net/en/langlearninginruss/Angiolini (accessed July 1, 2019).

172 Louis Viansson-Ponté, Les jésuites à Metz: Collège Saint-Louis, 1622-1762, Collège Saint Clément, 1852-1872 (Strasbourg: F. X. Le Roux, 1897), 348-49.

173 N. P. Popov goes further, claiming that in addition to the Jesuits' lack of identification with a specific nationality, their supposed antipathy toward the papacy had prompted hopes that some sort of Russian "Gallicanism" might grow, thereby shifting more power to the monarchy over its Catholic subjects. Cited in Donald W. Treadgold, The West in Russia and China: Russia, 1472-1917 (Cambridge: Cambridge University Press, 1973), 132.

174 James T. Flynn, "The Role of the Jesuits in the Politics of Russian Education, 1801-1820," Catholic Historical Review 56, no. 2 (1970): 249-65, here 265.

175 Francesco Gusti, Historya kościoła ruskiego, trans. Jan Ławrowski, 2 vols. (Kraków: Nakł. iczcionkami Karola Budweisera, 1857-58), 2:129. 
(1736-1812), who had been present when the initial oral approbation of the Society had been given by the pope in 1783 .

Hostility from the Uniate hierarchy also harried the Russian Society. Bishop Jason Smogorzewski (1715-88), metropolitan of Kiev, fired off letters to Rome detailing alleged Jesuit misdeeds. Woven into these developments was a seldom expressed but very real animosity among ethnic groups. Ethnic Poles (who made up perhaps the majority of Jesuits at any time in White Russia) were historic enemies of Russia. Ukrainians had responded with only moderate enthusiasm to the Society's efforts to establish a Ukrainian Greek Catholic (Uniate) Church, and many Orthodox Ukrainians regarded this church as a hostile intrusion from the West (which might mean Habsburg-controlled Hungary). Jesuit missionary work among the Armenians was unlikely to impress Orthodox Russians to whom this restive minority was a potential problem.

Catherine's ambivalent attitude toward Western Europe cast its shadow over all of the developments. Her new Jesuit subjects were potential tools with which to counter Western European influence, but at the same time they were sworn to obedience to a Western European monarch (the pope). They were also inevitably shaped by the Society's centuries of engagement with the cultures of Western Europe. The Jesuits' sometime reputation as untrustworthy "cosmopolites" undoubtedly figured into the equation as well.

Despite these challenges, the Jesuits quickly took steps to establish a community in what is now Belarus, where they became formally known as the "Society of Jesus in White Russia." One of the first tasks faced by the community was the creation of institutions that both conveyed a sense of permanence and that also had the authority to promote stability and growth. To these ends, Stanisław Czerniewicz (1728-85) was elected the first vicar general "for life" in $1782,{ }^{176}$ and was succeeded by Gabriel Lenkiewicz (1722-98), an instructor of astronomy and mathematics. ${ }^{177}$ The existence of the Society within Russia was formally and openly recognized by Rome on March 7,1801 when Pius VII (17421823, r.1800-23) issued the breve Catholicae fidei. ${ }^{178}$ In this document, the pope

176 Czerniewicz had spent a decade in Rome as secretary to the Polish assistancy, and later as archivist for the Polish province. Marek Inglot, La Compagnia di Gesù nell'Impero Russo (1772-1820) e la sua parte nella restaurazione generale della Compagnia (Rome: Università Gregoriana, 1997), 47.

177 Załeski calls Lenkiewicz "astronome célèbre même hors de son pays," (an astronomer renowned even outside of his native land) but Lenkiewicz's principal contribution to the Połosk community was as a teacher of architecture. Załęski, Jésuites de la RussieBlanche, 1:245.

178 The Latin text of the breve is found in Sanctissimi in Christo Patris et Domini nostri Domini Pii [...] (Rome: Apud Lazarinum Cameræ Apostolicae Typographum, 1814), and with an English translation in Promising Hope: The Suppression and Restoration of the English 
decreed that henceforth the leader of the Society in Russia, where there were now two hundred Jesuits, be known as praepositus generalis (superior general), not vicar general, as had previously been the case. Francis Kareu (1731-1802), a native of Lithuania and the region's third vicar general, ${ }^{179}$ thus became the first Jesuit to hold the title of praepositus generalis since the death of Lorenzo Ricci $\left(1703-75\right.$, in office $\left.175^{8-73}\right)$ in the Castel Sant'Angelo twenty-six years earlier. ${ }^{180}$

The change in terminology found in Catholicae fidei, while having little impact on the day-to-day functioning of the Jesuits in Russia, revealed Rome's understanding of (and hopes for) the future of the Society: the idea of complete restoration became more openly endorsed. The following year, a general congregation was held that elected Gabriel Gruber (in office 1802-5), a Habsburg Jesuit from Slovenia who during the years after the suppression had gained renown for his engineering skills. Gruber had already spent many years in Russia and had established a connection with the mathematician Leonhard Euler (1707-83), who then resided in St. Petersburg. ${ }^{181}$ In the tradition of medieval wizards, Gruber is also credited with the creation of a "mechanical head" that could supposedly answer questions put to it in many languages. ${ }^{182}$ In a more practical vein, Gruber recruited and trained temporal coadjutors (coadjutores temporales) as architects, painters, and workmen. ${ }^{183}$ Unfortunately for the Russian Jesuits, the energetic and gifted Gruber was killed in a fire two years later. Gruber was succeeded by Tadeusz Brzozowski (1749-1820, in office 181420), a Prussian-born scholar with considerable knowledge of the workings of the Russian Empire. ${ }^{184}$ Some of the Jesuits who migrated to Połock, hardened no doubt by anti-Catholic persecutions, objected to Brzozowski's relatively broadminded view of the mission of the Society in Russia, which included the

Province of the Society of Jesus, ed. Thomas McCoog (Rome: Institutum Historicum Societatis Iesu, 2003), 312-18.

179 The term vicar general had implied the provisional status of the Society as a religious order.

180 Daniel Beauvois, "Les jésuites dans l'Empire russe (1772-1820)," Dix-huitième siècle 8 (1976): 257-72, here 260 .

181 Stanislav Južnič, "Euler and the Jesuits in Russia," Quaderns d'història de l'enginyeria 9 (2008): 219-47.

182 Yahor Lazouski et al., "Characterisation and Rehabilitation of One of the Historical Buildings of the Polotsk Campus of the Polotsk State University," in Nondestructive Techniques for the Assessment and Preservation of Historic Structures, ed. Luisa Maria da Silva Gonçalves, Hugo Rodrigues, and Florindo Gaspar (Boca Raton: CRC Press, 2018), $115^{-24}$, here 116.

183 G. O'Brien, "The Survival of the Jesuits in White Russia," Irish Monthly 42, no. 497 (1914): 597-607, here 605-6.

184 William H. Rule, Celebrated Jesuits, 2 vols. (London: John Mason, 1852-53), 2:389. 
teaching of Orthodox Christianity in Jesuit schools. In 1814, Brzozowski, now the superior general of the restored international Society, found himself in the difficult position of trying to expand the Society's educational role in Russia while confronting criticism that Jesuits were proselytizing among prominent Greek Catholic families. ${ }^{185}$

Joseph Coincé (1764-1833) had been ordained a priest before the French Revolution and entered the Society in 1805 in Riga, then ruled by Russia. Trained as a physician, he was a fervent reformer of what he saw as the degenerate morals of the citizens of Riga and became superior in $1813 .{ }^{186}$ With the support of the governor of Riga and several French émigrés, Coincé established a school for noble girls whose curriculum included cooking (not a common undertaking of the old Society), and even managed to initiate construction of a hospital, just weeks before the issuance of Sollicitudo omnium ecclesiarum. ${ }^{187}$

The years of exile in Russia were characterized by a wide variety of undertakings. Jesuit historical writing was greatly diminished during this period, but never entirely extinguished; meanwhile, Russians maintained an interest in the history of the Society. In 1784, Freemason and philanthropist Nikolai Novikov (1744-1818) published a series of articles in a Moscow periodical outlining the history of the Society in sometimes critical terms. ${ }^{188}$ In a letter of 1820, Prince Demetrius Augustine Gallitzin (1770-1840) also asserted that early in the century Jesuits had aggressively sought to convert Jews, although the prince's knowledge must have been second-hand since he lived in North America. ${ }^{189}$

Jesuit skill at self-promotion had not expired either: a permanent display of Jesuit inventions was installed in the Society's church in St. Petersburg. ${ }^{190}$ The Society also initiated six new missions, which were supposed to be directed only to Catholics, but which very probably included proselytizing among Orthodox. ${ }^{191}$ Meanwhile, in the capital, St. Petersburg, a pension for aristocratic boys had opened in 1803 , but did not endure for long. The educational

185 Ferdinand Baur, Church and Theology in the Nineteenth Century, trans. Robert F. Brown and Peter C. Hodgson, ed. Peter C. Hodgson (Eugene, OR: Cascade Books, 2018), 115.

186 Felix Joseph Lipowsky, Geschichte der Jesuiten in Tyrol (Munich: Jakob Giel, 1822), x.

187 Crétineau-Joly, Histoire, 6:35.

188 K. A. Papmehl, Freedom of Expression in Eighteenth Century Russia (The Hague: Martinus Nijhoff, 1971), 96.

189 Crétineau-Joly, Histoire, 6:27.

190 William A. James, "The Jesuits' Role in Founding Schools in Late Tsarist Russia," in Religious and Secular Forces in Late Tsarist Russia: Essays in Honor of Donald W. Treadgold, ed. Charles E. Timberlake (Seattle: University of Washington Press, 1992), 48-64, here 61.

191 Marek Inglot, "The Society of Jesus in the Russian Empire (1772-1820) and the Restoration of the Order," in Maryks and Wright, Jesuit Survival, 67-82, here 75 . 
techniques employed in these schools may not have strictly followed the model of the Ratio. One foreign observer claimed that the Jesuits were first sent to St. Petersburg where they were trained in the methods of Prussian reformer Johann Ignaz von Felbiger (1724-88), which laid special stress on memorization of terminology and downplayed the classics. ${ }^{192}$ While this interpretation of Jesuit teacher training may be somewhat erroneous, it is certain that the Society in Russia was prepared to adapt to the new and challenging circumstances in which it found itself, a trait it had inherited from its pre-1773 ancestor and could be traced back to Antonio Possevino's (1533-1611) sojourn in Moscow in the sixteenth century. ${ }^{193}$

The secondary impact of Jesuit schooling in the Russian Empire during these years was not insignificant. The Society, while reaching out to a wide spectrum of students, continued, whenever possible, to train elites. In the Decembrist revolt of 1826 , eight of the officers involved had been trained in Jesuit schools. ${ }^{194}$ Jesuit schools served not only as a vehicle for presenting Western ideas and methods of inquiry but also provided the social context for the gathering of youths, both aristocratic and ambitious. Again, there was nothing new about this function for Jesuit schools, but the particular characteristics of Russian society, with its vast population of serfs and scattered urban centers led by a generally despotic and non-Catholic monarchy, created both risks and exciting possibilities for this Jesuit project.

Połock became the incubator of a key figure of the restored Society: the future superior general Johann (Jan) Phillip Roothaan (1785-1853, in office 182953). Born in Amsterdam in 1785, Roothaan arrived in White Russia in 1804 and was ordained priest in Połock in $1812 .{ }^{195}$ The same day that Roothaan arrived at the novitiate in Daugavpils, Melchior Malevé, a native of South Brabant, also reached the city. ${ }^{196}$ Malevé was soon on his way to the Caspian Sea in the company of Father Jan Woyszwiłło (?-1842) and temporal coadjutor Krzysztof

\footnotetext{
192 Max Joseph Okenfuss, The Rise and Fall of Latin Humanism in Early Modern Russia: Pagan Authors, Ukrainians, and the Resiliency of Moscow (Leiden: Brill, 1995), 221.

193 See Jan Joseph Santich, Missio Moscovitica: The Role of the Jesuits in the Westernization of Russia 1582-1689 (New York: Peter Lang, 1995), 85-106 for an account of Possevino's mission to Moscow.

194 Janet M. Hartley, Russia, 1762-1825: Military Power, the State, and the People (Westport: Praeger, 2008), 6o. See also Marc Raeff, Michael Speransky: Statesman of Imperial Russia 1772-1839 (The Hague: Martinus Nijhoff, 1969), 61.

195 Édouard Terwecoren, Esquisse historique sur le T. R. P. Roothaan, XXIe général de la Compagnie de Jésus, 3rd ed. (Brussels: Vandereydt, 1857), 21.

196 Melchior's brother François (1770-1822), also a Jesuit trained in White Russia, later ministered to Catholics in Maryland.
} 
Rodziewicz (dates unknown). Malevé mastered several of the local languages and died in Astrakhan thirteen years later. In a Volga community identified as "Krasnopolis" (but otherwise obscure), the former Sulpician father Fidèle de Grivel (1769-1842) maintained a mission. ${ }^{197}$

From 1811 until 1820, when it was expelled once more from Russia, ${ }^{198}$ the Society also operated Siberian missions that were directed at the local Catholic population (officially, the Society was banned from making conversions from the Orthodox faith). The fathers were by no means welcomed by Orthodox ecclesiastical authorities. ${ }^{199}$ The ambition and scope of these undertakings call to mind the projects of the pre-1773 Society. The initiative for the first mission, launched in 1811, had originated with Polish Catholics exiled to Irkutsk. A second mission was born in Tomsk in 1815. Marek Inglot cites a Catalogus for this second expedition, but little is known about its roots in the pre-restoration community in Połock. ${ }^{200}$ Meanwhile, there were other rivals to deal with: the Society was hostile to the efforts of the Russian Bible Society, founded in 1812 in St. Petersburg with the objective of distributing Bibles in the vernacular.

A few Polish Jesuits, among them Grzegorz Arakiełowicz (1732-98), migrated eastward to the Society's new headquarters in White Russia, becoming the core of a community that would endure for four decades. ${ }^{201}$ Others stayed in the diminished remnant of Poland-Lithuania: Andreas Strzecki (1737-97) worked at the Vilnius observatory and became the dean of the physics faculty, ${ }^{202}$ publishing Ephemerides astronomicae (Daily astronomical records) in $1778 .{ }^{203}$ But a striking fact about the Jesuit community surviving in White Russia was its lack of direct connection, on either a personal or philosophical level, with the experiences of former Jesuits in pre-1773 Poland. The Society that persevered within the Romanov autocracy was in some ways new, but in others it looked backward in its techniques and goals, a tendency that its complete dependence on an autocratic monarch did nothing to change.

\footnotetext{
197 Crétineau-Joly, Histoire, 5:33.

198 In 1820 , the Society had 356 members in Russia, an increase of seventy-four from five years earlier. Załęski, Jésuites de la Russie-Blanche, 2:423.

199 Anna Peck, "Between Russian Reality and Chinese Dream: The Jesuit Mission in Siberia, 1812-1820," Catholic Historical Review 87, no. 1 (2001): 17-33, here 20-22.

200 Inglot, Compagnia di Gesù, 119.

201 Sommervogel, Bibliothèque, 1:495.

202 F. [François] L. de la Fontaine, Chirurgisch-medicinische Abhandlungen verschiedenen Inhalts Polen betreffend (Breslau: Wilhelm Gottlieb Korn, 1792), 252.

203 Göttingische Anzeigen von gelehrten Sachen (Göttingen:Johann Christian Dieterich, 1778), 640.
} 
By 1780 , a novitiate had been set up in Połock and novices were being admitted. Twenty-one priests had already been ordained. ${ }^{204}$ By 1809, Połock had fifty-nine scholastics in training, Dunaburg (Daugavpils) in Latvia had twenty-four, ${ }^{205}$ and an additional eighteen were being trained at four other sites. All told, 617 Jesuits worked in Połock, and by early 1812, on the eve of Napoleon's invasion of Russia, the collegium, which counted among its faculties one devoted to the "exact sciences," had been elevated to the rank of academy. ${ }^{206}$ Połock soon became the nerve center for an ambitious project: two additional collegia, two residential secondary schools, three missionary houses, and nine missionary stations constituted the Jesuit presence in the region. Połock was moreover a hub of plans for the restoration of the Society. The ways in which the Połock Jesuits engaged with the local population closely resembled the strategies of the pre-1773 Society: confraternities were established, processions and public presentations were staged. Jesuits also conducted rural missions among the Latvians, speaking their language. ${ }^{207}$ The Jesuit presence in Połock acquired an air of permanence and stability: in 1782, a general congregation was held, electing Stanisław Czerniewicz (1728-85) superior general (in office 1782-85). The following year, Pius VI confirmed the existence of the Society, but only orally and not in writing, ${ }^{208}$ for there was still much need of caution. Still, word reached White Russia of this positive development, and hopes were further raised. In 1784, Luigi Fortis (1748-1829), who would become the twentieth superior general of the Society (in office 1820-29), established contact with the Russian Jesuits from his residence in Parma. Also during these

204 Stephen Hawkes-Teeples, "Russia," in Worcester, Cambridge Encyclopedia of the Jesuits, 702-4, here 703 .

205 Among those scholastics who underwent training in Dunaburg was Anton Kohlmann (1771-1836), who arrived in Baltimore in 1806 and contributed to the establishment of confessional privilege in US law. Daniel F. Schlafly, "General Suppression, Russian Survival, American Success: The Russian Society of Jesus and the United States," in Burson and Wright, Jesuit Suppression, 201-15, here 210.

206 Irena Kadulska, "The Połock Academy (1812-1820): An Example of the Society of Jesus's Endurance," in Burson and Wright, Jesuit Suppression, 83-98, here $83-84$. The term "university" carried precise connotations in the lobbying conducted by Father Brzozowski for the promotion in rank. A Jesuit "university" would be notably free of instructors carrying the contagion of Enlightenment ideas, and instead would be patriotic and loyal to the monarchy. Flynn, "Role of the Jesuits," 257.

207 Załenski, Jésuites, 421-22. See also J. [Jean] Gagarin, Les jésuites de Russie (Paris: Victor Palmé, 1872), 1:169-81, and Gagarin, review of Lettres et documents inédits, by Auguste Carayon, Études religieuses historiques et littéraires 4, no. 4 (1869): 459-69.

208 Liber saecularis historiae Societatis Jesu ab anno 1814 usque ad annum 1914 (Rome: Typis Polyglottis Vaticanis, 1914), 7 . 
years the Bohemian ex-Jesuit Josef Dobrovský (1753-1829) traveled to Russia in search of documents carried off from Prague during the Thirty Years' War (1618-48). The library of the Połock collegium was enhanced by donations and eventually held thirty-five thousand (or according to some sources, fifty thousand) volumes, and in 1787 , the Połock community acquired a printing press. The Bourbon regimes learned of these developments and fumed but could do nothing.

During the reign of Catherine's son Paul I (1754-1801, r.1796-1801), the Society's status remained largely unchanged, and if anything improved, since in 1800 the emperor entrusted education in Lithuania, where Catholics made up the majority, to the Society, and allowed the Jesuits to operate a parish church in St. Petersburg. Paul saw a direct connection between the Society's work and his own security as ruler, writing to his ambassador at the Porte: "Knowing all the advantages that a good government can derive from the Jesuit Institute, whose end is to elevate youth and inspire love and fidelity for sovereigns, I have resolved to restore this order in my dominions and to grant it great prerogatives." ${ }^{209}$ The tsar was apparently not familiar with the propaganda pieces of Pombal or even with the Ratio studiorum, but his linking of the elevation of youth with loyalty to a sovereign anticipated the way the restored Society would be viewed by some absolutist rulers. In 1801, Paul visited Połock and toured the collegium, the only Russian monarch ever to do so. ${ }^{210}$

With the existence of the Society now openly sanctioned in Russia, the language of instruction in the Russian Society's schools was switched in 1802 from Latin to Russian, which represented a significant advance in engaging the local population and was an indication of how far the Russian Society was prepared to go beyond the program of the Ratio. French was also taught at the St. Petersburg collegium. ${ }^{211}$ But things gradually took a turn for the worse once Alexander I (1777-1825, r.1801-25) succeeded his murdered father. At first, the protection of yet another Romanov autocrat seemed assured, but two years after the worldwide restoration of the Society Alexander banished the Jesuits from both Moscow and St. Petersburg. In 1820, the Society was banned from the entire Russian Empire.

209 Paul I to Vasily Stepanovich Tonara [?], December 8, 180o, cited in Crétineau-Joly, Histoire, 5:416. Author's translation.

210 M. J. [Marie Joseph] Rouët de Journel, La Compagnie de Jésus en Russie: Un collège de jésuites à Saint-Pétersbourg, 180o-1816 (Paris: Perrin, 1922), 86.

211 Rouët de Journel, Compagnie, 155. 
Jesuits trained in Połock during these years formed a link to the most ambitious undertakings of the restored Society. Francis Dzierozynski (1779-1850) joined the Society in 1806 and after the expulsion of the Jesuits from the Russian Empire sailed to the United States, where he became a teacher and administrator at Georgetown. ${ }^{212}$ No doubt the experience of working where support of the absolute ruler might be withdrawn at any moment encouraged a resilience and flexibility that served these Jesuits well when they migrated to new lands. The negative side of this experience was a wariness and even a sense of persecution that followed veteran members of the restored Society to the New World and endured for decades. As Raymond A. Schroth puts it: "Deep in the American Jesuit consciousness was the realization that the political powers that had almost destroyed them once were always ready to strike again." ${ }^{213}$ Anti-Catholic riots and the attack on the Medical College of St. Louis University, a Jesuit institution, both in 1844 , seemed to justify this anxiety.

The last Jesuit to remain in the Russian Empire, the Luxembourger Gilles Henry (1772-1856), left in $1827 .{ }^{214}$ Henry, who had arrived in Daugavpils the same day as Roothaan and Malevé, was one of the most gifted Jesuits laboring in Russia during the first decade of the nineteenth century. He became proficient in several of the languages spoken in the Caucasus, including Armenian. Upon reaching the outpost of Mozdok, where many Polish prisoners who had rebelled against the tsar's rule had gathered, Henry set to work under horrifying conditions to try to alleviate the suffering of the colony. He eventually persuaded the rebels to surrender to the authorities. These missions, in contrast to the modern sophistication of Jesuit schools in the capital, must have had at times a baroque flavor. A letter of Henry, a former Paccanarist, written in Mozdok and dated 1812, is full of references to the presence of the devil and to miraculous cures, while Henry denounces the "lascivious and impious singing" of Muslims, and reports approvingly of Christian converts seeking to baptize sick Muslim children. ${ }^{215}$

Henry's frequent companion, Fr. Józef Suryn (1773-1832), ministered to the "pagans" in Astrakhan and Georgia, journeying alone in a manner reminiscent

212 Anthony J. Kuzniewski, "Francis Dzierozynski and the Jesuit Restoration in the United States," Catholic Historical Review 78, no. 1 (1992): 51-73.

213 Raymond A. Schroth, "Death and Resurrection: The Suppression of the Jesuits in North America," American Catholic Studies 128, no. 1 (2017): 51-66, here 66.

214 Thomas O. Flynn, The Western Christian Presence in the Russias and Qājär Persia, c.176oc.1870 (Leiden: Brill, 2017), 377.

215 Letter of Gilles Henry, Mozdok, March 18, 1812, trans. C. [Conrad] M. Widman Woodstock Letters 1, no. 1 (1900): 56-6o, here 59 . 
of Jesuits of the old Society. ${ }^{216}$ Aloysius Moritz (or Moriz [1738-1805]), who missionized in the Volga port of Saratov, brought an extraordinary background to his work in Russia. Born in the Tyrol, Moritz reached China just a year before word of the suppression reached the missions there. He then returned to the empire and arrived in White Russia about 1776 , remaining in the Russian mission the rest of his life. ${ }^{217}$ The freedom of action enjoyed-if that is the word - by these Jesuits reflects the trust that the tsar (who had granted an audience to Henry) had placed in the Society, despite the vehement objections of the Orthodox clergy. Such successful undertakings no doubt made the sudden change in the Society's fortunes in Russia after 1815 even more disappointing.

Much in the story of the Society's years in Russia suggests the resolve and growing optimism of the Jesuits working there. But anxiety and risk also characterized their experience. Taking as a vantage point the summer of 1812, the Society could look back on some encouraging developments, but also on the destructive fury of the French Revolution and the impact of its exportation to much of the rest of Catholic Europe and to steady attrition through death of priests and brothers who had belonged to the Society in 1773 . This last figure was in no way matched by the number of new recruits coming to Połock. Napoleon himself, while not methodically anti-Jesuit in the mold of Pombal, was a destroyer of the old order and was just beginning his invasion of Russia. The emperor's seeming indifference to religious matters was different from the attitudes of other absolute rulers with whom the Society had engaged. Unlike Akbar (1542-1605, r.1556-1605) or the Kangxi Emperor (1654-1772, r.1661-1772), Napoleon did not bother to calculate how the Society might fit into his plans; he generally ignored the Jesuits - while forbidding them any role in the state he was creating. ${ }^{218} \mathrm{~A}$ consequence of the dislocation caused by Napoleon's re-

216 Halina Lichocka, "Miesięcznik połocki' (1818-1820): Kontekst historyczny i bibliografia zawartości," in Wkład jezuitów do nauki i kultury w Rzeczypospolitej Obojga Narodów i pod zaborami, ed. Irena Stasiewicz-Jasiukowa (Kraków: Wydaw. WAM, 2004), 631-62, here 651; Andrzej Woźniak, "Kultura ludowa Gruzji w relacjach polskich do początków XX w.," Etnografia Polska 27, no. 1 (1983): 297-320, here 302.

217 Constantin Simon, "The 19th-Century Volga Mission of the Society of Jesus," Archivum historicum Societatis Iesu 62 (1993): 43-86; Albert Chan, Chinese Materials in the Jesuit Archives in Rome, 14th-2oth Centuries: A Descriptive Catalogue (Abingdon: Routledge, 2015), 252.

218 "I shall never permit [the Society's] re-establishment in France." Letter to Joseph Fouché, October 9, 1805. Cited in John W. Padberg, Colleges in Controversy: The Jesuit Schools in France from Revival to Suppression (1815-1880) (Cambridge, MA: Harvard University Press, 1969), 3. However, in 1808, the emperor inserted a clause into the treaty with Persia that France had the right to send Jesuits to that country. Crétineau-Joly, Histoire, 6:40. 
treat from Russia was the death of nine Jesuits in White Russia. ${ }^{219}$ Well might the Jesuits of Połock view their future as one potentially filled with persecutions and uncertainty. Jesuits could nevertheless point to their usefulness to the Russian monarchy. They had served as agents of the Russian imperial government on a mission to dissuade the Qing from entering into trade arrangements with the British and were well regarded in some quarters for their pedagogy. Yet even before the expulsions and controversies of the nineteenth century had gained momentum, the Russian experience of the Society foreshadowed the insecurity that would remain a characteristic of life in the restored Society.

To understand the experience of the Jesuits under the Romanovs we must also remember the state of the Russian Orthodox Church during these years. Georges Florovsky (1893-1979) has characterized the period as an "ornate, dreamy and troubled" one for the church. ${ }^{220}$ As a spiritual and intellectual community, it had stood on the sidelines during the introduction of Francophile institutions by Catherine and retained a vivid and negative memory of Jesuits from encounters in the sixteenth and seventeenth centuries. Like many organizations experiencing a period of decline, it was instinctively defensive and sought to resist any advances of the Society, something that men like Gruber understood. Yet the Orthodox Church commanded the devotion and loyalty of millions, its ethos permeating all aspects of peasant life, and was often as much a part of the exiled Society's experience as the weather.

An outstanding characteristic of the Jesuits active in Russia during these years was the diversity of their backgrounds, perceptions, and foci. Gruber moved easily in the most exalted circles of Petersburg life while Henry reported on the infernal doings of a giant horned hound terrorizing the inhabitants of Mozdok. This diversity on balance was probably more of an asset than a liability since the Russian Society often had to speak with different voices in response to challenges coming from many directions in the years before their expulsion by Alexander I. But Henry's Jesuit persona, for all of its passion and commitment, looked backward to an earlier time and would have little to offer his brothers laboring in the United States, Britain, or even Italy.

219 "Viri illustres Societatis Jesu," Woodstock Letters 27, no. 1 (1898): 42-46, here 42. These "martyrs of charity" are not named.

220 Georges Florovsky, Ways of Russian Theology, trans. Robert L. Nichols (Belmont, MA: Nordland Publishing, 1979), 143. 


\section{$9 \quad$ Hanging On in China}

News of the pope's suppression of the Society did not reach Beijing until November $1774^{221}$ and did not result in the expulsion of Jesuits from China, but the arrival of the breve ushered in a period of uncertainty, danger, decline, and inevitable extinction. Emperor Ch'ien Lung (1711-99, r.1735-96), whose Summer Palace had been embellished with the help of Jesuit missionaries, allowed the fathers to remain in Beijing, but in the provinces the persecution of Catholics reached a climax in $1784-85 .{ }^{222}$ In 1791 , Jesuits, carrying on much as they had before 1773 , tried unsuccessfully to influence Chinese imperial policy toward Lord George Macartney's (1737-1806) embassy to Beijing and likewise failed to establish a Russian Jesuit collegium in China. ${ }^{223}$ Despite the failure of this mission, Jesuits continued to have a presence in the Qing capital, and one of the Połock fathers sent on a later mission to the Russian east, Giovanni Grassi (1775-1849), went on to play a key role in the development of Georgetown University: indeed, virtually every Jesuit sent to the mission in the United States had some connection to Połock. A year after the issuance of Dominus ac redemptor, forty-one Jesuits remained in China: thirteen French, twelve Chinese, eleven Portuguese, three from Austria and other parts of the empire, and two Italians. ${ }^{224}$ Of the Chinese Jesuits, at least four were priests; the names of three Chinese Jesuits have survived, although their positions in the Society are not clear: Louis Ko (?), Étienne Yang (1733-98?), and Jean Yao (1722-96). ${ }^{225} \mathrm{~A}$ few years after the suppression, Yang worked in Guangzhou but was soon arrested. In 1787, after his release from prison in Beijing, Yang traveled

221 Joseph Krahl, China Missions in Crisis: Bishop Laimbeckhoven and His Times, 1738-1787 (Rome: Gregorian University Press, 1964), 223.

222 John D. Young, Confucianism and Christianity: The First Encounter (Hong Kong: Hong Kong University Press, 1983), 91.

223 Gregory Afinogenov, "Jesuit Conspirators and Russia's East Asian Fur Trade, 1791-1807," Journal of Jesuit Studies 1, no. 2 (2015): 56-76.

224 Fernando Mateos, S.J., "Suppression and Restoration of the Society of Jesus in China"; http://www.riccimac.org/doc/monographs/1/suppression_and_restoration_of_the_soci ety_of_jesus_in_china.pdf (accessed July 2, 2019).

225 Catherine Marin, "La mission française de Pékin après la suppression de la Compagnie de Jésus en 1773," Transversalités 107 (2008); doi: 10.3917/trans.107.00o9 (accessed July 2, 2019). Yang is probably the individual identified as Fr. Yang Dewang or Teh-Wang, who traveled to France in 1751 where he studied theology and science. Dai Nianzu, "The Development of Modern Physics in China: The 5oth Anniversary of the Chinese Physical Society," in Chinese Studies in the History and Philosophy of Science and Technology, ed. Fan Dainian and Robert S. Cohen (Dordrecht: Kluwer, 1996), 207-18, here 207. 
to Inner Mongolia where he probably died. ${ }^{226}$ Yao evangelized the Jiangsu peninsula and apparently remained there until his death. ${ }^{227}$ Luigi Cipolla (Cibolla [1736-after 1805]) arrived in Canton in 1771 with skills as a physician, and also served in the Society's bureau of astronomy. He is described as a "propagandist in Beijing in 1776," which probably means he was employed by the imperial government in some capacity as a composer of documents. ${ }^{228}$

Among the German-speaking Jesuits of China, Ignatz Sichelpart (1708-80) was perhaps the most renowned. A native of Bohemia, Sichelpart was an artist who worked with court painters to produce a backdrop for a meeting between the emperor and his Mongolian allies. ${ }^{229}$ On his seventieth birthday, the former Jesuit received an avalanche of gifts from the court, including a scroll inscribed by the emperor Qianlong himself.

Several Jesuit clockmakers remained active in China after 1773: unlike their counterparts in Europe, these men were always priests, which accorded them a higher status at court. Suggestive of the tales of Gruber's animated head is the automaton created sometime before 1786 by the French Jesuit Jean-Matthieu Tornu de Ventavon (Wang Dahong; Matou [1733-87]) that could write Manchu at the emperor's request. ${ }^{230}$

Among the few triumphs that the remaining members of the Society's mission in China could claim was the conversion of Yi Beyok (dates unknown), a Korean who after his baptism by Fr. Jean Joseph de Grammont (1736-1812?) $)^{231}$ returned to his homeland where he died in prison for his proselytizing efforts. ${ }^{232}$

226 Arnold H. Rowbotham, Missionary and Mandarin: The Jesuits at the Court of China (Berkeley: University of California Press, 1942), 336.

227 Jean-Pierre Duteil, Le mandat du ciel: Le rôle des jésuites en Chine (Paris: Editions arguments, 1994), 128.

228 Stanislav Južnič, "Central-European Jesuit Scientists in China, and Their Impact on Chinese Science," Asian Studies 2, no. 3 (2015): 89-118, here 104-5; doi: 10.4312/as.2015.3.2.89-118 (accessed July 2, 2019).

229 Patricia Berger, Empire of Emptiness: Buddhist Art and Political Authority in Qing China (Honolulu: University of Hawai'i Press, 2003), 15.

230 Catherine Pagani, "Eastern Magnificence \& European Ingenuity": Clocks of Late Imperial China (Ann Arbor: University of Michigan Press, 2001), 54.

231 Grammont served as a music teacher at the emperor's palace and lived a comfortable life with slaves and a chariot. Jie Gao, "The Influence of Chinese Musical Instruments on the Violin: A Practice Guide of Three Musical Techniques" (DMA diss., University of North Texas, 2017), 3; https://digital.library.unt.edu/ark:/67531/metadc1011757/m2/1/high _res_d/GAO-DISSERTATION-2017.pdf (accessed July 2, 2019); Tang Kaijian, Setting Off from Macau: Essays on Jesuit History during the Ming and Qing Dynasties (Leiden: Brill, 2015), 151.

232 Antton Egiguren Iraola, True Confucians, Bold Christians: Korean Missionary Experience, a Model for the Third Millennium (Amsterdam: Rodopi, 2007), 229-39. 
Yi's story has the flavor of martyrdom stories of the pre-suppression Society, but his case was the exception rather than the rule.

One important holdover of the pre-1773 mission to China was the continuing operation of astronomical observatories. The most notable Beijing-based exJesuit astronomer of this period was the director of the Beijing Astronomical Bureau and physician-pharmacist skilled in calendar calculations José Bernardo de Almeida (Suo Dezhao, Yué-Tch'ang [1728-1805]). ${ }^{233}$ His predecessor, Luís Rodrigues (An Guoning [1729-96]), made numerous observations of lunar and solar eclipses. ${ }^{234}$ Jesuits continued to man the observatory in Beijing until 1803. Other former Jesuits, especially those who had labored in the provinces, were less fortunate. Jean-Baptiste de la Roche (1722-85) died while being transported in chains en route to Beijing; others perished on the long sea voyage into exile. Augustin Haller von Hallerstein (Liu Songling [1703-74]) was the last Jesuit astronomer sent to Beijing, having already worked in Goa and Macau. Following his death, eight of his letters to his brother were published by György Pray (1723-1801).235

During the years of suppression, ex-Jesuits who had served in China, among them Jean-Joseph-Marie Amiot (1718-93), contributed to the massive Mémoires concernant l'histoire, les sciences, les arts, les moeurs, les usages, \&c. des chinois (Memoirs concerning the history, sciences, arts, mores, and customs, etc. of the Chinese) a work based largely on Chinese primary sources. ${ }^{236}$ Louis Antoine de Poirot (He Qingtai) (1735-1818), who died in Beijing more than forty years after the issuance of Dominus ac redemptor, was the last of the Jesuits who used their artistic skills to engage the Chinese court. A gifted linguist, de Poirot produced translations of the Old Testament into Manchu and the New Testament into Chinese. ${ }^{237}$ The talents of Pierre-Martial Cibot (Beidu

233 Stanislav Južnič, "Central European Jesuit Scientists in China, and Their Impact on Chinese Science," Asian Studies 3, no. 2 (2015): 89-118, here 105.

234 Luís Saraiva, "The Jesuit Mathematicians of the Portuguese Assistancy and the Portuguese Historians of Mathematics (1819-1940)," in History of Mathematical Sciences: Portugal and East Asia III; The Jesuits, the Padroado, and East Asian Science, 1552-1773, ed. Luís Saraiva and Catherine Jami (Singapore: World Scientific Publishing, 2008), 1-31, here 23.

235 Imposturce CCXVIII. in dissertatione B. Cetto [...] de Sinensium imposturis detectee et convulsce: Accedunt epistola anecdote R. P. Augustini e comitibus Hallerstein ex China scriptae (Buda: Typis Regiae Universitatis, 1781), 1-lv.

236 Yoko Nii, "The Jesuit Jean-Joseph-Marie Amiot and Chinese Music in the Eighteenth Century," in Europe and China: Science and Arts in the 17th and 18th Centuries, ed. Luis Saravia (Hackensack, NJ: World Scientific, 2012), 81-92, here 81.

237 Erling von Mende, "Problems in Translating the Bible into Manchu: Observations on Louis Poirot's Old Testament," in Sowing the Word: The Cultural Impact of the British and Foreign Bible Society 1804-2004, ed. Stephen K. Batalden, Kathleen Cann, and John Dean (Sheffield: 
Han Guoying [1727-80]) were in the fields of botany and mechanics: in particular, his work on the Chinese garden was published in the eighth volume of the Mémoires. ${ }^{238}$ Far less is known about the French-born Giuseppe Panzi (Pan Tingzhang)(c.1734-after 1794), a Jesuit portraitist (a priest? a brother?) and student of Pompeo Batoni (1708-87), who arrived in Beijing in about 1772 and died there in obscurity forty years later, probably the last Jesuit remaining in China. ${ }^{239}$

In 1773, six Portuguese Jesuits lived in Beijing: João Seixas (1710-85), Félix da Rocha (1713-81), José de Espinha (1722-88), Inácio Francisco (1725-92), and astronomers José Bernardo de Almeida and André Rodrigues whom we have already met. Rocha succeeded Hallerstein as director of the Astronomical Observatory in Beijing and in 1774 traveled to eastern Tibet to create a map of the region, and possibly also to assist in the production of artillery pieces for the emperor's army, returning to the region three years later. ${ }^{240}$ In addition, Father Manuel da Mota (1720-82) remained in Hunan province, Father Agostinho Avelar (1725-88) remained in Hubei, and José de Araújo (1721-80?) and Inácio Pires (1724-80?) remained in Jianxi. ${ }^{241}$ Little is known about these Jesuits living outside of the metropolis, but their lives were no doubt difficult. Araújo (Gong An-duo-ni) had previously been accused of distributing religious tracts and proselytizing. ${ }^{242}$ These men attempted to carry on in the modes that had worked for the old Society, but time was running out.

The post-1773 Chinese mission of the Society, despite its very real accomplishments, must have acquired an increasingly melancholy aspect as Jesuits aged and died with no prospect of successors to continue their work. When the embassy of Lord Macartney arrived in China, one of the points it stressed (albeit

Sheffield Phoenix Press, 2004), 149-68, here 151. Thomas Campbell (1848-1925) says Poirot was also a musician, whose talent had charmed the emperor. Thomas J. Campbell, The Jesuits, 1534-1921: A History of the Society of Jesus from Its Foundation to the Present Time (New York: Encyclopedia Press, 1921), 680.

238 Che-Bing Chiu, "Vegetal Travel: Western European Plants in the Garden of the Emperor of China," in Qing Encounters: Artistic Exchanges between China and the West, ed. Petra tenDoesschate Chu and Ning Ding Ning (Los Angeles: Getty Research Institute Publications, 2015), 95-110, here 96. Cibot also designed a water clock that featured moving figures and bird songs.

239 Michael Sullivan, The Meeting of Eastern and Western Art (Berkeley: University of California Press, 1989), 89; Marco Musillo, The Shining Inheritance: Italian Painters at the Qing Court, 1699-1812 (Los Angeles: Getty Research Institute, 2016), 50.

240 Joanna Waley-Cohen, "China and Western Technology in the Late Eighteenth Century," American Historical Review 98, no. 5 (1993): 1525-44, here 1539-40.

241 António Graça de Abreu, "Os bens dos últimos Jesuítas portugueses em Pequim," Revista de cultura 37 (1988): 55-62.

242 Lars Peter Laamann, Christian Heretics in Late Imperial China (Abingdon: Routledge, 2006), 104 . 
with only moderate success) was that the English were now the European leaders in the production of mechanical devices. ${ }^{243}$ The era of Jesuits bearing fascinating toys from Europe was over, and the few Jesuits remaining in China were in no position to argue the point. Gottfried von Laimbeckhoven (1701-87), an Austrian Jesuit who had arrived in China as a missionary in 1738 and had conducted astronomical and pharmacological studies there, served as bishop of Beijing for five years following the suppression, the last year of which was embittered by a power struggle with a newly appointed coadjutor bishop and by the ongoing persecution of Christians. He spent his last days bowed down by the realization that the China mission would soon vanish.

Gabriel Brotier (1722-89), the last librarian of Louis-le-Grand and noted classicist, never traveled to China but contributed to Sinology through his summary of the letters of three Jesuits who had missionized in China in the seventeenth and eighteenth centuries. The French edition of his Mémoire sur les Juifs établis en Chine (Memoir of the Jews established in China) appeared in 1774 in the Lettres édifiantes and has remained an important source on the Chinese Jews of Kaifeng. ${ }^{244}$ But Brotier's work looked backwards, and no Jesuits engaged in ethnological research in China for many decades after the publication of Brotier's summary.

The gradual extinction of the Jesuit mission to China marked the end of an important intercultural dialogue. Never again would a non-European imperial system be drawn through curiosity to the performances of European Christian clergy: the attitude of the Chinese court was less receptive in the nineteenth century, and even if there had been keen interest, Jesuits were no longer in a position to impress their hosts with unknown technological marvels and new artistic forms from the West. The growing threat of European imperialism also made the offerings of any westerner suspect.

The widely differing experiences of ex-Jesuits in China contain echoes of the Society's precarious position in Russia, but the Chinese mission had far less access to the network of former Jesuits. As in Russia, the attitude of the monarch toward individual Jesuits might be at odds with government policies toward Catholics more broadly. Qianlong may have esteemed Father Sichelpart's addition to a diplomatic mission, but the persecution of Jesuits nevertheless continued during his reign. Former Jesuits in China were unlikely to attempt

243 Benjamin A. Elman, “The Jesuit Role as 'Experts' in High Qing Cartography and Technology," Taida lishi xuebao 31 (2003): 223-50, here 247. Macartney also represented a single foreign power, while the ex-Jesuits were often divided among themselves and originated from different countries, a point not lost on the imperial court.

244 Jeremy Clark, "From Kaifeng to Shanghai via Rome and Paris: Jesuits and the History of Judaism in China," in Bernauer and Maryks, Tragic Couple, 125-44, here 139. 
innovation or engagement with broader cultural trends: both their formation and the circumstances in which they found themselves militated against this. Their "way of proceeding" thus died out with them, with few native-born disciples to carry on their studies or other activities.

In India, the overwhelming majority of the Jesuits were Portuguese subjects, and with the expulsion of the Society from the empire, scores were rounded up and first housed with other Catholic orders. ${ }^{245}$ Over half these men were then placed on ships headed for Portugal; at least twenty-four died en route. ${ }^{246}$ Those who survived faced long years in Portuguese prisons, a fate that at least theoretically they might have escaped had they been willing to leave the Society — but most remained firm. ${ }^{247}$ Two Jesuit bishops stayed behind, denied support from the Portuguese government but willing to depend on Providence and the loyalty of their flocks for their survival. One of them, Salvador dos Reis, bishop of the Serra (1702-1777), lived into the era of the suppression

Yet many Jesuits escaped the roundup and continued their labors, sometimes joining other religious orders or becoming parish priests, and often living under harsh conditions. A few missionized as wandering swamulus, a term for missionary sannyasis, holy men who had abandoned worldly life, in the remote Deccan interior. ${ }^{248}$ In the south, French Jesuits, among them the distinguished linguist Gaston-Laurent Coeurdoux (1691-1779), stayed on. ${ }^{249}$ Indeed, not a single French Jesuit opted to return to his homeland. The last surviving member of the Mughal mission, Francis Xavier Wendel (Wendell), who was born in 1726, arrived in India in $175^{1}$ and lived until $1812 .{ }^{250}$ This ex-Jesuit, a skilled linguist and cartographer, has been variously described as German and Belgian, and accused of being "rather shadowy": indeed, he had contact

245 Stephen Neill, A History of Christianity in India: 1707-1858 (Cambridge: Cambridge University Press, 1985), 214.

246 Charles J. Borges, The Economics of the Goa Jesuits, 1542-1759: An Explanation of Their Rise and Fall (New Delhi: Concept Publishing, 1994), 128.

247 Neill, History of Christianity, 125 .

248 Robert Eric Frykenberg, Christianity in India: From Beginnings to the Present (Oxford: Oxford University Press, 2008), 345.

249 Coeurdoux made major contributions to comparative philology, although his work in this area was not published until after the restoration of the Society. Thomas R. Trautmann, Aryans and British India (London: Yoda Press, 2004), 37.

250 Although other sources give his death as 1803, his will is attested for May 7, 1804; http:// discovery.nationalarchives.gov.uk/details/r/D338559 (accessed July 2, 2019). 
with a Russian traveler named Czernichef and was even accused of being a British agent. Wendel's colleague, the Tyrolian-born Fr. Joseph Tieffentaler (Tiefenthaler [1710-85]), published a description of Hindustan, received financial support from the British in Calcutta, ${ }^{251}$ and worked with Wendel to execute a map of the regions northwest of Delhi that was published a decade after the suppression..$^{252} \mathrm{~A}$ few of the remaining Jesuits were brothers, although not much is known about their later activities.

The scope and even the strategies of the Society in India differed from those in China: although there were powerful rajahs with splendid courts, Jesuits had not aimed at impressing court culture with their learning and inventions. When the suppression came, the refuges for former Jesuits in India were not buttressed by observatories or diplomatic assignments. Consequently, the relationship between former Jesuits and lower-status Indians was often far closer than what existed between the Chinese peasantry and the remaining fathers, although future research into the missionary work of men such as Yang Dewang (1733-98) may require a revision of this view.

At the time of the suppression, as many as 121 Jesuits may have resided in England.253 Anti-Catholic sentiment was still strong in some quarters, as demonstrated by the Gordon Riots of 1780 , in which hundreds died. But the mere fact that these riots had been triggered by a bill granting more rights to Catholics suggested that the official position toward Catholics had mellowed greatly during the previous century. Supporters of the Jesuits could be found among the rural aristocracy and gentry, with the result that a small but significant number of ex-Jesuits were able to live unmolested in the homes of their English Catholic friends. Two such refuges for Jesuits were Linstead Lodge, the residence of Lord Teynham (c.1708-81) in Kent, ${ }^{254}$ and Wardour Castle, the seat

251 R. [Rajesh] K. Kochhar, "Secondary Tools of Empire," in Discoveries, Missionary Expansion, and Asian Cultures, ed. Teotónio R. de Souza (New Delhi: Concept Publishing, 1994), 175-83, here $179-81$.

252 Carte generale du cours du Gange et du Gagra, dressee sur les cartes particulieres du P. Tiefentaller, J. missionnaire apostolique dans l'Inde. 1784.

253 [Franz Xaver Wernz and Ludwig Schmitt], Synopsis historice Societatis Jesu (Regensburg: Typis Frederici Pustet, 1914), 368.

254 George Oliver, Collections, Illustrating the History of the Catholic Religion in the Counties of Cornwall, Devon, Dorset, Somerset, Wilts, and Gloucester (London: Charles Dolman, 1857), 306. 
of Barons Arundell. Arriving in England in 1767, Charles Fleury (1739-1825) resided in both homes, fending off attempts by Anglican clergy to prevent him from proselytizing, ${ }^{255}$ and serving as chaplain to the Arundells for a quarter of a century. Fleury, who also went by the name of Forrester, remained in England after the restoration, where he died. ${ }^{256}$ Another Jesuit to serve as chaplain at Wardour was John Jenison (1729-92), whose correspondence with other Jesuits conveys some of the gossipy, leisure-dominated culture of upper-class English Catholics among whom many of these English Jesuits moved. ${ }^{257}$

Thomas Falkner (1707-84), a native of Manchester, returned from the South American missions in 1767 and spent the rest of his life in England. Falkner is probably unique among ex-Jesuits in that he was awarded an MD from the University of St. Andrews in 1774 in recognition of his medical knowledge, although he had never studied the subject in university. ${ }^{258}$ Another former Jesuit with deeper Scottish connections was John Farquharson (1699-1782). Farquharson had acquired a detailed knowledge of Scottish Gaelic and in $177^{2}$ deposited in the Scots College at Douay a manuscript in his own hand of old Scottish poems, which have been cited as a source for the famous poem that was actually written by James Macpherson $(1736-96),{ }^{259}$ but which was later lost. Farquharson lived in the valley of Braemar after the suppression and produced no further known manuscripts.

Ireland, where seventeen (or according to some sources, nineteen) ex-Jesuits remained after 1773, became an incubator for future Jesuits training there as early as 1801 for life in a "Society now reviving."260 The last former Jesuit in Ireland died in 1811, but one of his students, Peter Kenney $(1779-1841),{ }^{261}$ pur-

255 Henry Foley, Records of the English Province of the Society of Jesus, 7 vols. (London: Burns \& Oates, 1877-83), 5:311-14.

256 Obituaries (Wigan: Catholic Record Society, 1913), 165.

257 Geoffrey Holt, "The Letters from Rome of John Thorpe, S.J., to Charles Plowden, S.J., 1784-92," Recusant History 28, no. 3 (2007): 434-57.

258 Miguel de Asúa, Science in the Vanished Arcadia: Knowledge of Nature in the Jesuit Missions of Paraguay and Río de la Plata (Leiden: Brill, 2014), 185.

259 “Three Works on Ossian," British Critic, and Quarterly Theological Review 33 (1809): 163-80, here 171.

26o Thomas Hughes, History of the Society of Jesus in North America Colonial and Federal Documents: Volume I, Part II; Nos. 141-224 (1605-1838) (London: Longmans, Green \& Co., 1910). Hughes's primary focus was Canada, but he identified documents related to Ireland as well.

261 Kenney later served as visitor to the Jesuit community in Georgetown. John Gilmary Shea, Memorial of the First Century of Georgetown College, D.C. (Washington, DC: P. F. Collier, 1891), 68. 
chased Castle Brown in 1814 to be a school for the restored Society. ${ }^{262}$ Kenney had trained in Palermo before the Society had been expelled from the Kingdom of Naples and was ordained priest in $1808 .^{263}$

English Jesuits who had operated a collegium in St. Omers, then in French territory, fled in 1762 to the neighboring Austrian Netherlands, where three years later they were able to open a Grand Collège anglais in Bruges. ${ }^{264}$ With the promulgation of Dominus ac redemptor, the Jesuits were compelled to move again, this time to Liège, where the prince-bishop allowed them to create an Académie anglaise, which lasted until 1794, when the arrival of French troops in the city caused them to relocate to the Stonyhurst estate of Thomas Weld $\left(175^{-1810)} .^{265}\right.$ In the meantime, Habsburg officials had looted the Society's libraries, throwing away as many as four hundred thousand volumes considered to be theological rubbish. ${ }^{266}$ These events were the first act in the massive destruction of the book and visual cultures in continental Europe developed by the baroque Society and would culminate in the continent-wide vandalism carried out two decades later during the French Revolution. ${ }^{267}$ These processes occurred as the Holy Roman Empire came to an end and German monasteries were secularized, which caused the further dispersal and loss of Jesuitica, thereby depriving the restored Society of key resources. Collectively, this destruction counts as one of the most significant events in the Society's history.

The experiences of the Bollandists, a Jesuit research institute founded in the seventeenth century, were somewhat less catastrophic but still indicative of the hardships faced by the remnant of the Society's book culture. These scholars first moved from Antwerp to Coudenberg Abbey in Brussels, and then when Josephinian reforms closed the abbey to the Premonstratensian Abbey

262 "Proceedings of the Second Session of the Fifth Parliament of the Kingdom of Great Britain and Ireland," Gentleman's Magazine 115 (1814): 679-82, here 680.

263 See Thomas J. Morrissey, Peter Kenney, S.J., 1779-1841: The Restoration of the Jesuits in Ireland, England, Sicily, and North America (Washington, DC: Catholic University of America Press, 2014).

264 Paul Shore and Maurice Whitehead, "Crisis and Survival on the Peripheries: Jesuit Culture, Continuity, and Change at Opposite Ends of Continental Europe, 1762-1814," History of Universities 4 (2010): 173-205, here 177.

265 Maurice Whitehead, English Jesuit Education: Expulsion, Suppression, Survival, and Restoration (London: Routledge, 2013), 191.

266 O'Malley, Jesuits, 8 o.

267 In 1794, French agents in occupied Cologne were given the task of removing artworks and books from the former Jesuit gymnasium "pour enricher la République" (to enrich the Republic). Jeffrey Chipps Smith, "The Jesuit Artistic Diaspora in Germany after 1773," in Maryks and Wright, Jesuit Survival, 129-47, here 146. 
of Tongerlo in Westerlo, ${ }^{268}$ where the fathers remained until 1794 when the French revolutionary government seized the property and expelled them. Reassembling the Bollandist project had to wait nearly a quarter of a century after the restoration, since the financially strapped Society could spare few resources. Now reconstituted in Brussels, the small team of Jesuits had to contend with the lack of a library and rivals in their field of endeavor. ${ }^{269}$ Their work in the nineteenth century was respectable but a mere shadow of their achievements in the seventeenth and eighteenth.

By 1803, the Society had established an English province made up of thirtythree fathers, which affiliated itself to the Jesuits of White Russia (thirty-four ex-Jesuits remained unaffiliated). ${ }^{270}$ The same year, thirty-five ex-Jesuits renewed their vows at Stonyhurst under Marmaduke Stone (1748-1834) as first provincial of the restored English province. The right to organize community life had been granted to the scattered ex-Jesuits twenty-five years earlier. Despite lingering anti-Catholic sentiment, Jesuit connections to gentry and higher aristocracy endured, though literary and scientific achievements were few. The fates of former Jesuits in the lands of the Bohemian crown, where the Society had held vast tracts of land and dominated higher education, played out differently from in the Bourbon monarchies. These men were also much more productive scholars than their confrères in the British Isles. ${ }^{271}$

In Bohemia, the sympathetic attitude of Maria Theresia toward individual Jesuits fostered a measure of continuity after $1773 .{ }^{272}$ Distinguished scientists

268 Derek Beales, Prosperity and Plunder: European Catholic Monasteries in the Age of Revolution, 1650-1815 (Cambridge: Cambridge University Press, 2003), 221.

269 Hippolyte Delahaye, The Work of the Bollandists through Three Centuries, 1615-1915 (Princeton: Princeton University Press, 1922), 179-81.

270 John Morris, Catholic England in Modern Times (London: Burns \& Oates, 1892), 56.

271 Paul Shore, "The Suppression of the Society of Jesus in Bohemia," Archivum historicum Societatis Iesu 65 (1996): 138-56.

272 The empress paid the suppressed Society an indirect but telling compliment in 1775 when she rejected a proposal to create a Vienna academy on the grounds that it would have to be staffed almost entirely by Jesuits who had just been deprived of their jobs and homes. Derek Beales, Enlightenment and Reform in Eighteenth-Century Europe (London: I. B. Tauris, 2005), 70. Maria Theresia also offered the chair in Greek at the University of Milan to Bernardo Zamagna (Džamanjić [1735-1820]), although the former Jesuit 
such as Joseph Stepling $(1716-78)^{273}$ were permitted to continue their research, and the last group of pre-suppression Jesuit university teachers became the mentors for a generation of intellectuals associated with the Czech National Revival, during which the Czech language again became a vehicle of literary and scientific discourse (c.1780-1850). Stepling's student, Stanislav Vydra (1741-1804), served as rector of the Prague University and produced a textbook on differential calculus. ${ }^{274} \mathrm{~A}$ few former Jesuits even bridged the cultures of late baroque universalism and romantic nationalism. The contributions of Josef Dobrovský $\left(1753^{-1829)}\right.$ to linguistics and history earned him the title "patriarch of Slavonic studies," while Ignaz Cornova (1740-1822) set forth a patriotic version of Czech history that would form the foundation of an influential nineteenth-century nationalist narrative. ${ }^{275}$ The prolific Germanophone historian František Pubitschka (1722-1807) became known as the historiographus patriae (historiographer of his homeland). Yet Pubitschka's reputation as a scholar suffered in a dispute with Dobrovský over the veracity of a pious legend regarding St. Jan Nepomucký (c.1345-93) as the defender of the seal of confession, with Pubitschka defending the more traditional view and the younger Dobrovský taking a more critical position. ${ }^{276}$ The dispute between the two former Jesuits is a reminder that ex-Jesuit intellectual life was far from monolithic and was frequently riven by generational gaps.

In Slovenia, the post-1773 career of Jurij Japelj (1744-1807) in some ways paralleled the experiences of the more successful Habsburg ex-Jesuits. Japelj served in many ecclesiastical posts and was eventually appointed bishop of Trieste. His longstanding interest in the Slovene language and in comparative Slavic philology led him to begin translating, with Blas Kumerdey (1738-1805), the Bible from the Vulgate. ${ }^{277}$ Japelj left an unfinished Slovene grammar at the

declined the appointment. De vita et scriptis Bernardi Zamagnae patricii Rhacusini commentariolum [...] Francisci Mariae Appendini (Biograd na Moru: Typis Joannis Demarchi, 1830), 21-22.

273 Ivana Čornejová and Anna Fechtnerová, Životopisný Slovník Pražské Univerzity: Filozofická a teologická fakulta 1654-1773 (Prague: Univerzita Karlova, 1986), 444-45.

274 Elementa calculi differentialis et integralis conscripta a Stanislao Wydra (Prague: Apud Ioan. Ferd. Nob. a Schönfeld, 1783).

275 Hugh LeCaine Agnew, Origins of the Czech National Renascence (Pittsburgh: University of Pittsburgh Press, 1993), 38.

276 Franz Pubitschka, Ehrenrettung des heiligen Johann von Pomuk oder Nepomuk (Prague: Johann Diesbach, 1791); Josef Dobrowsky, "Streitschriften über die Existenz des heil. Johann von Nepomuk," Literarisches Magazin für Böhmen und Mähren 3 (1787): 101-26.

277 August Dimitz, History of Carniola: From Ancient Times to the Year 1813, trans. Andrew J. Witter, 4 vols. ([Bonita Springs, FL]: Slovenian Genealogy Society International, 2013), 4:262. 
time of his death. Another Slovenian, Theodor Kravina Cronstain (Cronstein [c.1726-89]), belongs to the intellectual history of both Slovenia and of the Habsburg monarchy more generally. Born near Maribor in about 1726, Cronstein eventually became the director of the Theresianum, a school for young nobles in Vienna, producing in 1773 a survey of the training in economics offered at this institution. Following the suppression, Cronstein relocated to Zwettl in Lower Austria where he assisted in the translation of a textbook on the physics of immovable bodies. Cronstein died in Zwettl in 1789. ${ }^{278}$ The parallels in Cronstein's career with that of Gruber, also a Slovenian, are notable. Both were experts in mechanics and both served in important administrative roles. On the other side of the Alps, the ex-Jesuit Ignaz von Weinhart $\left(1705^{-87}\right)$ became rector of the University of Innsbruck and lectured in German on mechanics. ${ }^{279}$ Along with Peter Anich (1723-66), Weinhart also helped produce one of the first examples of modern cartography, the Atlas Tirolensis (Atlas of the Tyrol $[1774]) \cdot{ }^{280}$

Several Croatian former Jesuits continued their historiographic publications and research after 1773. Josip Mikoczy-Blumenthal (1734-180o), who served as librarian in the Faculty of Law in Zagreb, promulgated a theory that the Croatians were descended from the Medes of ancient Iran in his Hrvati rodom Slaveni, potekli od Sarmata potomaka Medijaca (Croats of Slavic origin, descended from Sarmatian descendants of the Medes [1797]). ${ }^{281}$ Andrija Blašković (1726-96) published Historia universalis Illyrici (The universal history of Illyria) in $1794,{ }^{282}$ and Franjo Ksaver Pejačević (1707-81), a native of Osijek of

278 Johann Nepomuk Stoeger, Scriptores provinciae Austriacae Societatis Jesu ab ejus origine ad nostra usque tempora (Vienna: Typis Congr. Mechit., 1856), 48; Stanislav Južnič, "Theodor Kravina Cronstain i njegove veze s isusovačkim kolegijem u Varaždinu (obljetnica četvrtine tisućljeća imenovanja varaždinskog profesora Cronstaina rektorom Theresianuma u Beču)," Radovi Zavoda za znanstveni rad HAZU Varaždin 28 (2017): $353^{-66}$, here 355 .

279 Armin Denoth, "Professor Matheseos Dr. phil. Ignaz von Weinhart, S.J. 1705-1787 zum 30o. Geburtstag des Gründers der Experimentalphysik an der Universität in Innsbruck," Berichte des Naturwissenschaftlich-medizinischer Vereins in Innsbruck 92 (2005): 351-61.

280 [Andreas Alois di Pauli], "Lebensgeschichte des Landmessers Blasius Hueber: Mit unständlichen Nachrichten von den Arbeiten des Geodeten von Oberperfus [Part Three]," Archiv für Geographie, Historie, Staats- und Kriegskunst 7 (1816): 267-72, here 268.

281 Ivan Ljubičić, "Podrijetlo Hrvata Tragom Hrvatskoga Imena" (PhD diss., University of Zagreb, 2012), 11; http://darhiv.ffzg.unizg.hr/id/eprint/2420/2/DIPLOMSKI-Ljubicic_Ivan .pdf (accessed July 2, 2019).

282 Teodora Shek Brnardić, "From Acceptance to Animosity: Trajectories of Croatian Jesuit Historiography," 9-10; https://bib.irb.hr/datoteka/935258.Shek_-_Croatian_Jesuit_Historio graphy.pdf (accessed July 2, 2019). 
Bulgarian descent, wrote on both Bulgarian and Serbian history. ${ }^{283}$ Like their confrères elsewhere in the Habsburg lands, these scholars were concerned with questions of the origins and early histories of the populations from which they themselves originated, and in the case of Mikoczy-Blumenthal, his theory has continued to have its adherents until today. Ignacije Szentmartony (SzentMártony Ignácz [1718-93]), a Jesuit claimed by both Hungarian and Croatian historians, spent seventeen years in a Portuguese prison following his expulsion from Brazil and was finally freed in 1777 through the intervention of Maria Theresia. Returning to Croatia, Szentmartony composed a Croatian textbook for German speakers, the first of its kind. ${ }^{284}$ Another Hungarian Jesuit missionary who had worked in Brazil, Joannes Nepomuk Szluha (1723-1803), returned to Hungary where he became the rector of the collegium in Györ until the suppression. His activities for the next thirty years are not known; he died in Graz in $1803 .{ }^{285}$ A German Jesuit missionary in Brazil, Anselm Eckart (1721-1809), also spent years in a Portuguese prison until the fall of Pombal. Eckart's description of Brazilian fauna was published eight years later, ${ }^{286}$ and the ex-Jesuit eventually made his way to Połosk, where he spent the rest of his life. The career of Ignaz von Born (1742-91) suggests both how deeply engaged the community of Jesuits and former Jesuits was in the intellectual life in the Habsburg lands and simultaneously how ambiguous the position of some of these men might be in the post-suppression landscape. Von Born, a native of Transylvania, left the Society before undertaking his final vows and may have been the model for Sarastro in Wolfgang Amadeus Mozart's (1756-91) Zauberflöte (Magic flute). ${ }^{287}$ His interests ranged from metallurgy to literary satire. Von Born's Masonic connections point to another direction toward which products of Jesuit culture might gravitate in the 1780 s. $^{288}$ While a significant number of Habsburg exJesuits retained a sense of baroque piety, others set out toward new frontiers.

283 Penka Danova, "Franjo Ksaver Pejačević a-t-il écrit une histoire des bulgares?," Études balkaniques 54, no. 2 (2018): 205-30.

284 Einleitung zur kroatischen Sprachlehre für Teutsche ([Varaždin]: [1783]). Szentmartony's work addresses the Kajkavian dialect.

285 Menyhárt Ágnes, “Magyar jezsuiták Brazíliában, 1753-176o," Világtörténet 38, no. 2 (2016): 219-322, here 322.

286 Christoph Gottlieb von Murr, ed., Reisen einiger Missionarien der Gesellschaft Jesu in Amerika (Nuremberg: Johann Eberhard Zeh, 1785), 451-58.

287 Rachel Cowgill, "New Light and the Man of Might: Revisiting Early Interpretations of Die Zauberflöte," in Art and Ideology in European Opera: Essays in Honour of Julian Rushton, ed. Rachel Cowgill, David Cooper, and Clive Brown (Woodbridge: Boydell Press, 2010), 194-221, here 205 .

288 Tim Mehigan and Barry Empson, "Introduction," in Karl Leonhard Reinhold, Essay on a New Theory of the Human Capacity for Representation, trans. Tim Mehigan and Barry 
Alois Blumauer (1755-98), who became a Jesuit a year before the suppression, went on to write verse set to music by Mozart ("Lied der Freiheit" [The song of freedom]), to compose attacks on the Society, and to construct an epic poem praising the reforms of Joseph II. Blumauer's works, seen as a challenge to the absolutist spirit of Francis II (1768-1835, r. as holy Roman emperor 1792-1806; as emperor of Austria 1804-35), were banned for a decade after his death. ${ }^{289}$

Habsburg Hungary likewise provided some career paths for former Jesuits, although the religious composition of the kingdom included far more nonCatholics so that the educational influence of the Society in 1773 was far less dominant than in the Czech lands. The most influential former Jesuit in the region during the first years of the suppression had in fact left the Society years earlier: Adam František Kollár de Keresztén (1718-83), a polymath whose accomplishments included the coining of the term ethnologia and the construction of an argument for the legal bases of Habsburg rule in Hungary, was also court librarian in Vienna and the author of a pioneering work on the history of the Rusyn. Kollár saw himself as a subject of the Hungarian crown, but not an ethnic Hungarian, calling himself instead "Pannonius." His contribution to the Ratio educationis, ${ }^{290}$ a rationalized curriculum promoting dynastic loyalty and civic virtue, suggests how far he had come from the values of the Jesuit Ratio studiorum of 1599, yet Kollár was an important part of the Viennese intellectual milieu that sustained ex-Jesuits after 1773. Kollár's contemporary and colleague, Joseph Hilarius Eckhel (1737-98), was professor of antiquities and numismatics at the University of Vienna, a post he held for twenty-four years. Styled an abbé following the suppression, Eckhel published a study of the numismatic collections of the grand duke of Tuscany and produced a textbook on numismatics for Habsburg schools. ${ }^{291}$

A trio of ex-Jesuit Hungarian historians exercised an immense influence on Hungarian historiography at the turn of the nineteenth century. György Pray is renowned for having discovered the Codex Pray, which contains the Halotti beszéd és könyörgés (Funeral oration and prayer), dated to about 1199 and the

Empson (Berlin: De Gruyter, 2011), x; Nicholas Till, Mozart and the Enlightenment (London: Faber \& Faber, 1992), 191.

289 Barbara Becker-Cantarino, Aloys Blumauer and the Literature of the Austrian Enlightenment (Bern: Herbert Lang, 1973), 99.

290 Ratio educationis totiusque Rei litterariae per Regnum Hungariae, 2 vols. (Vienna: Trattern, 1777). József Ürményi (1741-1825), sometimes incorrectly identified as an ex-Jesuit, oversaw the completion of this document. Jean Bérenger, A History of the Habsburg Empire, 1700-1918, trans. C. A. Simpson (London: Routledge, 1997), 94.

291 Joseph Hilarius Eckhel, Kurzgefaßte Anfangsgründe zur alten Numismatik (Vienna: Kurzbeck, [1786?]). 
oldest surviving continuous Hungarian (and Uraltic) text. ${ }^{292}$ Pray, who in 1777 was appointed "historiographus Hungariae" (historiographer of Hungary), was a meticulous compiler of documents and served as the librarian of the University of Buda. His catalog of the rare books housed in this collection was a major advance in the curating of libraries in Central Europe.

István Kaprinai (Kaprinay [1714-85 or 1786) shared with Pray a desire to preserve the monuments of Hungarian history. Although Kaprinai was more active before 1773, he remained a mentor for younger ex-Jesuit historians and continued a correspondence with the leading lights of the Hungarian Enlightenment during his final years. The career of István Katona (1732-1811) extended the furthest into the years of the suppression. Katona produced a forty-two-volume work, Historia critica Regum Hungariae (Critical history of the kings of Hungary), that emphasized source criticism and remains an important collection of documents from the Middle Ages. In the 1790s, Katona, now the chief librarian of the archbishop of Kalocsa, taught at the local seminary and produced a steady stream of historical and devotional works. ${ }^{293}$ All three of these scholars used scholarly techniques reflecting the universalist approaches of the old Society, but each contributed to national consciousness in a region that was never overwhelmingly Catholic or oriented toward Rome.

Maximillian (Miksa) Hell (Höll [1720-92]) is probably best described as a Habsburg Jesuit. Born in Habsburg Hungary in what is now Slovakia, Hell's native language was German. In 1773, Hell was a distinguished astronomer and the director of the Imperial Observatory in Vienna, a post he was able to retain after the suppression. Hell soon made the acquaintance of Franz Anton Mesmer (1734-1815), to whom he introduced the idea that magnets might cure illnesses. ${ }^{294}$ Soon Hell was claiming credit for Mesmer's sensational but dubious "successes," and a very public feud followed. Meanwhile, Hell continued his work as an astronomer, publishing his findings in annual Ephemerides. ${ }^{295}$ Hell's relations with non-Catholic colleagues were particularly cordial, and even if his involvement with Mesmer in retrospect seems ill-advised, his role as

292 Szegedy-Maszák Mihály et al., A magyar irodalom történetei: A kezdetektöl 180o-ig (Budapest: Gondolat Kiadó, 2007), 70.

293 See, e.g., Orationes Stephani Katona [...] quas triduo exercitiorum spiritualium in hebdomada maiore (Pest: Matthiae Trattner, 1813).

294 Douglas J. Lanska and Joseph T. Lanska, "Franz Anton Mesmer and the Rise and Fall of Animal Magnetism: Dramatic Cures, Controversy, and Ultimately a Triumph for the Scientific Method," in Brain, Mind, and Medicine: Essays in Eighteenth-Century Neuroscience, ed. Harry Whitaker, C. U. M. [Christopher Upham Murray] Smith, and Stanley Finger (New York: Springer, 2007), 301-20, here 302.

295 Paul Shore, "Enduring the Deluge: Hungarian Jesuit Astronomers from Suppression to Restoration," in Maryks and Wright, Jesuit Survival, 148-61, here 149. 
mentor to a new generation of Habsburg scientists places him at the forefront of ex-Jesuits who continued to have productive and influential careers after 1773. Among Hell's students was Antonius (Antal) Martonfi (1747-99), who established an observatory in Alba Iulia (now Romania) in $1794 .{ }^{296}$ Hell's successor as observatory director, Franz de Paula Triesnecker (1745-1817), was also an ex-Jesuit and a prolific producer of astronomical treatises, ${ }^{297}$ as was Hell's distinguished rival, the Moravian-born Christian Mayer $(1719-83) \cdot{ }^{298}$

Habsburg Jesuit astronomers seem to have been well on the way to establishing a dynasty when the disaster of 1773 struck. The success of these scientists and their ability to continue their work was certainly fostered by the political climate, but we should also give thought to the Society's still effective recruitment processes and to the educational opportunities found within the Austrian province. The lack of other avenues for budding scientists in the region, the newness and relative unimportance of the Academy of Sciences in Vienna, and Joseph II's interest in practical mechanics are additional factors that sustained the work of these ex-Jesuits.

A few Hungarian Jesuits had "sought the Indies" of the Western Hemisphere, and among those Ferenc Xavér Éder $(1727-72 / 73)$ was one of the handful who returned to Hungary after expulsion from the Spanish Empire. Éder had worked among the Moxos people of Peru, and his manuscript describing them was published some years after his death. ${ }^{299}$ Although Éder lacked access to libraries, his work shares with that of his contemporary Kollár an interest in the "patriae" of specific populations, and in their languages.

For two centuries, the Society's impact on Hungarian secondary education had been immense, but traces of its legacy faded quickly after the issuance of the papal breve. The last classes of the Jesuit academia in Buda completed their studies in 1777, taught by two instructors who had begun their careers as Jesuit novices. ${ }^{300}$ The program of the Ratio soon vanished from the educational landscape of Hungary.

296 Antonius Martonfi, Initia astronomica speculae Batthyanianae Albensis in Transilvania (Alba Iulia: Typis Episcopalibus, 1798).

297 Robert A Garfinkle, “Triesnecker, Franz (Francis) de Paula," Biographical Encyclopedia of Astronomers, ed. Virginia Trimble et al., 2 vols. (New York: Springer Reference, 2014), 1:1149.

298 Franz Martin Pelzel, Boehmische, maehrische und schlesische Gelehrte und Schriftsteller aus dem Orden der Jesuiten (Prague: Im Verlag des Verfassers, 1786), 239-41.

299 Ferenc Xavér Eder, Descritio provinciae Moxitarum in Regno Peruano, ed. Pál Makó de Kerek (Buda: Typis Universitatis, 1791); Bartusz-Dobosi László, Jezsuiták és conquistadorok harca az indiánokért a XVII-XVIII. században (Budapest: Szent Gellért Kiadó, 2001), 67-74.

300 Madzsar Imre, "A budai jezsuita akadémia története," Magyar pedagógia: A Magyar Tudományos Akadémia Pedagógiai Bizottságának folyóirata 35 (1926): 1-12, here 11. 
The relatively successful transition to a post-suppression existence that many ex-Jesuits in the Habsburg realms experienced was due to several factors. First and foremost, Maria Theresia and Joseph II continued to value these men as educators and as producers of scientific and mechanical literature of practical use to the monarchy. The absence of a large and organized Jansenist party anywhere in the region also worked in the favor of ex-Jesuits. ${ }^{301}$ While the Jesuits had many individual enemies among the elites of the various Habsburg territories, there was no personality comparable to Pombal in power and persistence plotting against the Society. Even Prince Anton Wenzel von Kaunitz (1711-94), the vastly influential and reform-minded chancellor, for a long time remained skeptical about some of the most shocking charges leveled at the Jesuits. ${ }^{302}$ The relative weakness of the Catholic Church in the multiconfessional Habsburg patchwork of territories likewise worked in the exJesuits' favor. Despite its efforts to hold back toleration, the Catholic hierarchy simply did not possess the capacity to oppress and control to the same degree as in Spain, Portugal, or the Papal States, thereby sparing Jesuits some degree of guilt by association. Finally, the ethnic and linguistic diversity of Habsburg Jesuits prevented them from being exclusively associated with one group to the disadvantage of other populations. The one great exception to this generalization was Transylvania, where the overwhelming majority of Jesuits were ethnic Hungarians, which did not endear them to Orthodox Romanians, or to local German-speaking Lutherans and Anabaptists.

Although the breve Dominus ac redemptor was not promulgated in the Ottoman Empire, the practical reality of the suppression of the Society throughout Western Europe meant that activities by former Jesuits in the Ottoman capital, already crippled by the expulsion of the Society from France, became much more difficult. The French ambassador to the Porte, François Emmanuel Guignard de Saint-Priest (1735-1821), encouraged the fathers to carry on their work while using ambiguous titles such as "temporary agents." ${ }^{303}$ Under these daunting circumstances, a few former Jesuits managed to continue their work for a decade after the suppression, at which point their missions were taken

301 The single most influential Austrian Jansenist in the 1750s, Archbishop Christoph Migazzi of Vienna (1714-1803), eventually became a supporter of ex-Jesuits in his battle with Joseph II over state intervention in ecclesiastical affairs. William David Bowman, Priest and Parish in Vienna: 1780 to 1880 (Boston: Humanities Press, 1999), 103.

302 Francis A. J. Szabo, Kaunitz and Enlightened Absolutism 1753-1780 (Cambridge: Cambridge University Press, 1994), 242.

303 Charles A. Frazee, Catholics and Sultans: The Church and the Ottoman Empire 1453-1923 (Cambridge: Cambridge University Press, 1983), 163. 
over by the Lazarists. ${ }^{304}$ A mission in Salonika, led by Robert-François Guérin du Rocher (1736-92), was apparently liquidated by command of the sultan in 1773 or $1774 .{ }^{305}$ There is also a report of two Jesuits, Dominque Venturi (dates uncertain) and Ferdinand Motté (dates uncertain), traveling to the Greek Isles in 1805 , but little is known of the outcome of their efforts. ${ }^{306}$

The Society's heritage survived in Greece in another, surprising way. In 180o, a monk of Mt. Athos, Nicodemos of the Holy Mountain (1748-1809), published a Greek-language Spiritual Exercises based on a popularization of Ignatius's Spiritual Exercises made by the Italian Jesuit Giovanni Pietro Pinamonti (16321703 ) in $1698 .{ }^{307}$ Nicodemos's text is much longer than Ignatius's but shares with the older text exercises of self-examination and an emphasis on the seeking of spiritual perfection.

Jesuits working in Egypt in 1773 were not exiled, but they were reduced to dire poverty. Three, all French, remained after the issuance of Dominus ac redemptor. One was a brother, Pierre Thonisson (1712-after 1773), who had taken his final vows in Damascus. Emmanuel Buman (1712-79), a veteran of decades of missionary work in Egypt, remained superior, and Charles Grimod, the last surviving Jesuit of the Cairo community, died in 1788.308

A few years later, one former Jesuit working in Constantinople made an outstanding contribution to Middle Eastern scholarship. Giambattista Toderini (1728-99) was born in Venice and after entering the Society taught at the Universities of Verona and Forli. A man of broad intellectual interests, Toderini wrote about topics as wide ranging as Benjamin Franklin's (1706-90) theory of lightning, the aurora borealis, and fossils. ${ }^{309}$ Like Boscovich, Toderini traveled with an ambassador of Venice to Constantinople in 1781, where he served as preceptor to the ambassador's son and remained until 1786 . The following year, he published an account of Turkish literature and music, including descriptions of libraries in Constantinople, the first work of its kind produced

304 Adina Ruiu, "Conflicting Visions of the Jesuit Missions to the Ottoman Empire, 1609-1628," Journal of Jesuit Studies 1, no. 2 (2014): 26o-8o, here 272.

305 Rocher was later martyred in Paris during the Terror. Jean Baptiste Nicolas Blin, Les martyrs de la Révolution dans le diocèse de Séez, 3 vols. (Bar-le-Duc: Typographie des Célestines, 1876), 1:76.

306 Crétineau-Joly, Histoire, 6:305.

307 Nikodemos may have been working from a French text of this work. Peter A. Chamberas, trans., Nicodemos of the Holy Mountain: A Handbook of Spiritual Counsel (New York: Paulist Press, 1989), 28. Thanks to Fr. Dragos Herescu for directing me to this source.

308 Charles Libois, S.J., ed., Monumenta Proximi Orientis, VI Égypte (1700-1773) (Rome: Institutum Historicum Societatis Iesu, 2003), 627, 608-9, 602-5.

309 Toderini co-authored Dissertazione sopra un legno fossile (Modena: Nella Stamperia di Giovanni Montanari, 1770) with another former Jesuit, Domenico Troili (1722-92). 
by a Western, Christian scholar. ${ }^{310}$ Toderini's achievements invite comparison with those of another ex-Jesuit with a Venetian connection, the Croatian Josip (Giuseppe) Marinovich (1741-1801), who published a detailed and sympathetic account of Armenian history, geography, and religious traditions a year before Toderini's work appeared. ${ }^{311}$ Thus despite the suppression, the 1780 s were one of the high points of Jesuit engagement with the cultures of the Middle East.

Meanwhile, Boscovich, arguably the most famous Jesuit scientist in 1773, relocated repeatedly, his career illustrating the declining prestige and vulnerability of Jesuit science and the insecurities of former Jesuit scientists. He was first enticed by the king of France to migrate to Paris, where he served as director of optics for the navy, receiving a handsome pension of eight thousand livres. After ten years, Boscovich migrated to Bassano in Vicenza and continued his research on optics and astronomy, dying in Milan in 1787, a frustrated and almost forgotten figure. ${ }^{312}$

Despite this often-gloomy climate, a few ex-Jesuit mathematicians and scientists remained productive and visible. In 1782, Juan Francisco Blasco (dates unknown) devised a project—never realized—whereby Spanish forces could make use of electric telegraphy to besiege Gibraltar. ${ }^{313}$ Joannes Baptista Horváth (1732-99) retained his university chair in Hungary and published textbooks on general physics, mathematics, and philosophy, the latter reflecting the ideas of Immanuel Kant (1724-1804). ${ }^{314}$ And Boscovich's atomic theory was advanced during the suppression years by the Scottish physicist John Robison (1735-1805), who praised the former Jesuit in an early edition of the Encyclopedia Britannica. ${ }^{315}$

Not enough is yet known about how ex-Jesuits understood and lived through their fates. A former Jesuit living in Russia, Nikodemus Musnicki (1765-1805), produced a Latin epic poem, De Christi ab inferis reditu (On Christ's return

310 Letteratura turchesca, dell'abate Giambatista [sic] Toderini [...] (Venice: G. Storti, 1787).

311 Compendio storico di memorie cronologiche concernenti la religione e la morale della nazione armena suddita dell'Impero ottomano, opera divisa in sei libri [...] dal marchese Giovanni de Serpos (Venice: Stamp. di C. Palese, 1786).

312 Ravi P. Agarwal and Syamal K. Sen, Creators of Mathematical and Computational Sciences (Cham: Springer, 2014), 206.

313 Dennis De Lucca, Jesuits and Fortifications: The Contribution of the Jesuits to Military Architecture in the Baroque Age (Leiden: Brill, 2012), 318.

314 Joannes Baptista Horvath, Declaratio infirmitatis fundamentorum operis Kantiani Critik der reinen Vernunft (Buda: Typ. Regiæ Universitatis Pestiensis, 1797). Yet other ex-Jesuits labored to combat "Kantisme."

315 J. [John] L. Heilbron, "Boscovich in Britain," in Relocating the History of Science: Essays in Honor of Kostas Gavroglu, ed. Theodore Arabatzis, Jürgen Renn, and Ana Simões (Cham: Springer, 2015), 99-116. 
from hell [1805]), which was an allegory for the suppression and exile of the Society. ${ }^{316}$ The assiduous efforts of ex-Jesuit Mihály Paintner $\left(1753^{-1826)}\right.$ to collate the records of the pre-suppression society in Hungary betoken far more than antiquarianism and show a desire to preserve a heritage in danger of being lost. ${ }^{317}$ Some ex-Jesuits may have suffered from depression following the loss of their Society—records mention a few men stricken with "melancholia." Not all Jesuits went quietly; a few attacked the pope who had suppressed the Society. ${ }^{318}$

Yasmin Haskell has highlighted the endurance of Latin as a medium of communication among ex-Jesuits, even in a period when the use of this language as an international medium of communication was in steep decline. ${ }^{319}$ The motives for this use of a declining language include a conservatism brought forth under duress and a rejection of the rising sentiments of nationalism, as well as the shared experience of the curriculum articulated in the Ratio. Nostalgia for the period when Latin had been the vehicle by which the Society's triumphs had been publicized is likely another reason, and indeed nostalgia proved a palpable element of the culture of the restored Society.

The Jesuit influence on literate culture lingered in sometimes unobtrusive ways. In the Habsburg lands, Jesuit libraries were incorporated into collections that became the cores of cultural centers that became key resources for nationalist movements that would emerge in the nineteenth century. A Serbianlanguage version of a classic Jesuit emblem text appeared as late as $1774,{ }^{320}$ and Jesuit-trained Romanian Uniate scholars pursued classical studies into the nineteenth century with the tools they had acquired in Jesuit schools. ${ }^{321}$

In the decades following Dominus ac redemptor, the fate of the Jesuit legacy on the Italian peninsula varied greatly. The arrival of the French in the Eternal City in 1798 resulted in an act of plunder with considerable symbolic

316 Yasmin Haskell, "Suppressed Emotions: The Heroic Tristia of Portuguese (ex-)Jesuit, Emanuel de Azevedo," Journal of Jesuit Studies 3, no. 1 (2016): 42-6o, here 47.

317 László Szilas, "Paintner Mihály Antal," Diccionario histórico de la Compañía de Jesús, ed. Charles E. O'Neill and Joaquín María Domínguez, 4 vols. (Rome: Institutum historicum S.I., 2001), 3:2948.

318 Ronald A. Binzley, "Ganganelli's Disaffected Children: The Ex-Jesuits and the Shaping of Early American Catholicism, 1773-1790," American Catholic Historian 26 (2008): 47-77.

319 Haskell, "Suppressed Emotions," 48.

320 Jasna Mijailović, "The Origin and Role of the Emblem in the Serbian Orthodox Church of the 18th Century on the Territory of the Habsburg Monarchy," lecture, Tenth International Conference Society for Emblem Studies, Christian-Albrechts-Universität zu Kiel, July 28, 2014, 1; http://arkyves.org/static/misc/kiel_mijailovic.pdf (accessed July 2, 2019).

321 Paul Shore,Jesuits and the Politics of Religious Pluralism in Eighteenth-Century Transylvania (Aldershot: Ashgate, 2007), 193. 
significance: the colossal silver statue of Ignatius in the Gesù in Roma was carried off. And, as we have seen, many former Jesuits remained highly visible in many fields. However, the saga of the restoration of the Society in Italy is to a significant degree the story of one ex-Jesuit working there. St. José (JosephMarie) Pignatelli (1737-1811) is the only former Jesuit of this period to have been canonized. ${ }^{322}$ Pignatelli's life is suggestive of some of the tensions and possibilities affecting Jesuit culture in the years before 1773, and of the ways former Jesuits attempted to move forward after Dominus ac redemptor. Born of the Spanish high nobility and initially a teacher in a collegium, Pignatelli had initially received praise from King Carlos III (1716-88, r.1759-88) for helping avert an attack on the governor of Zaragoza. Because of his noble status, Pignatelli was offered the chance to remain in Spain (if he left the Society) when his Jesuit brethren were expelled, an offer he declined. The next decades saw Pignatelli moving from Corsica to Genoa to Ferrara and Bologna. ${ }^{323}$ Unsuccessful in his attempts to reunite with the Jesuits of White Russia, Pignatelli finally settled in Abruzzi in 1797, where he became rector in $1799 .{ }^{324}$ Thanks to Pignatelli's efforts, the Jesuits were re-established in the Kingdom of the Two Sicilies on July 30,1804 by the papal breve Per alias, ${ }^{325}$ although this gain was short-lived: in July 1806, Joseph Bonaparte (1768-1844 r.1806-8), who had become king of Naples earlier that year, expelled the Jesuits. ${ }^{326}$ The community then moved north to Rome where they were allowed to establish a house. Pignatelli did not live to see the worldwide restoration of the Jesuits, but his constant efforts to secure and expand the Society's presence (typified by his success in restoring the Society in Sardinia in 1807) laid the foundations of a support network that would well serve the nineteenth-century Society and is the key figure in what has been called the "rallying" of the suppressed Jesuits. Pignatelli's friendship with Charles IV of Savoy (1751-1819, r.1796-1802) influenced the latter's decision, after his forced abdication, to take simple vows as a Jesuit, thus becoming in 1815 the only former monarch ever to enter the Society.

322 José A. Ferrer Benimeli, José Pignatelli, S.J. (1737-1811): La cara humana de un santo (Bilbao: Mensajero D.L., 2011).

323 Among the ex-Jesuits receiving Pignatelli's support in Bologna was Lars Birger Thjulén (1746-1833), who in 1797 became the Swedish consul in that city. Richard Wehner, Jesuiten im Norden (Paderborn: Bonifatius-Druckerei, 1974), 11.

324 Gabriel Bouffier, La vie du vénérable serviteur de Dieu, le père Joseph-Marie Pignatelli (Paris: Lecoffre, 1868), 227.

325 Henri Daniel-Rops, History of the Church of Christ, vol. 8, The Church in the Age of Revolution, trans. John Warrington (New York: Dutton, 1965), 139.

326 Thomas M. McCoog, "Est et non est': Jesuit Corporate Survival in England after the Suppression," in Maryks and Wright, Jesuit Survival, 162-77, here 174. 
The Duchy of Parma and Piacenza had already begun to welcome ex-Jesuits as early as $1793 \cdot{ }^{327}$ Parma was also the scene of a very modest revival of Jesuit cartography, in the form of decks of playing cards featuring maps of various countries and continents and probably executed by Bartolomeo Luigi Desprotti (1741-1819). ${ }^{328}$ By 1799, a Jesuit novitiate had been established in the duchy, the only one in Western Europe. ${ }^{329}$ By contrast, Mantua, where the Society had run a university, was in Lombardy and thus under the control of Maria Theresia, who obtained permission from the papacy to use Jesuit properties and the proceeds from the sale of Jesuit lands to create a state school system. ${ }^{330}$ In this city, the former Jesuit school was taken over by the Augustinians and the church was deconsecrated and eventually became a barn.

Because of its bizarre and scandalous aspects, the career of Niccolò Paccanari (also spelled Baccanari [1773?-1811?]) is a well-known episode from the years of suppression, but it also tells us something about the complex political and diplomatic situation former Jesuits and their allies faced. Paccanari, a native of the Trentino and onetime papal soldier, founded the Society of the Faith of Jesus in 1797 while still a layperson. ${ }^{331}$ The fortunes of the papacy were then at a low ebb: within the year, the pope would be taken prisoner by Napoleonic forces, and such desperate circumstances may have made powerful Catholic clerics and laypersons more sympathetic to Paccanari's vision of the resurrection of the Society in spirit, if not in name. In 180o, Paccanari, who welcomed former Jesuits into his Society, was ordained priest, but seven years later, having been accused of various crimes, he was condemned by the Holy Office for immorality and sentenced to ten years in prison, only to be freed by the French authorities in 1809 . He was then rearrested by papal authorities on

327 Duke Ferdinand of Parma's (1751-1802, r.1765-1802) letters to Pius VII urging the restoration of the Society "to stop the flood of impiety, illuminism and Jacobinism in my Empire" shed much light on the motives and expectations of those who become the allies of the restored Society. "Jesuit Restoration 1814"; http://www.sj2014.net/blog/category/italy (accessed July 2, 2019).

328 "Antiquariat Daša Pahor"; https://www.pahor.de/maps-and-prints/asia/asia-asie.html (accessed July 2, 2019). Desprotti (1741-1819) was a teacher of mathematics after the suppression and rejoined the Society in 1814. Bruno Signorelli, "Le gesuiti sabaudi durante la soppressione (1773-1814)," in Morte e resurrezione di un ordine religioso: Le strategie culturali ed educative della Compagnia di Gesú durante la soppressione (1759-1814), ed. Paolo Bianchini (Milan: Vita e Pensiero, 2006), 109-31, here 115-16.

329 Campbell, Jesuits, 677 .

330 Paul F. Grendler, The Jesuits and Italian Universities, 1548-1773 (Washington DC: Catholic University of America Press, 2017), 222.

331 Eva Fontana Castelli, "The Society of Jesus under another Name: The Paccanarists in the Restored Society of Jesus," in Maryks and Wright, Jesuit Survival, 197-211, here 200-1. 
another charge. His subsequent activities are obscure. In 1811, a decapitated body, which may have been Paccanari's, was fished out of the Tiber, although this identification is not certain.

Paccanari's creation, the Society of the Faith of Jesus, placed no emphasis on astronomy, poetry, ethnology, or the composition of edifying school dramas: instead, it favored spectacle and miracles, both of which had figured prominently in the mission work of a good many seventeenth-century baroque Jesuits but had not been a major part of the intellectual or spiritual life of the eighteenth-century Society. Ecstatic visions, never central to the Society's culture, were also part of Paccanari's repertoire. These elements, and Paccanari's often autocratic leadership style, made many former Jesuits hesitate. Some of the latter, such as Luigi Mozzi de' Capitani (1746-1813) were openly hostile, calling Paccanari's creation a "schismatic branch" of the true Society, now reconstituted in Russia. ${ }^{332}$ Later joining with the Society of the Sacred Heart, Paccanari's followers would prove to be neither numerous nor influential among the ranks of the restored Society, but for a time they played a highly visible role in plans to restore the Jesuits. The last known house of the Society of the Faith of Jesus, located in Rome, rejoined the restored Society in 1814.

Switzerland, never a major object of Jesuit attention, now became part of the Paccanarist story. In the canton of Fribourg, the authorities had obtained permission for several local ex-Jesuits to continue to teach, which they did until the arrival of revolutionary armies in $1798 .^{333}$ In 1805 , eight Paccanarists arrived in the French-ruled Republic of Valais in southwest Switzerland to reorganize a local grammar school. ${ }^{334}$ By 1810 , these men were linked to the Society in Russia. Simultaneously, ex-Jesuit Nikolaus Joseph Albert von Diessbach (Diesbach [1732-98] $)^{335}$ founded groups of laypersons in Turin called Amicizia Cristiana (Christian friendship) and Amicizie Sacerdotale (Priestly friendship), which soon attracted Pius Brunone Lanteri (1759-1830), who in turn founded the Congregation of the Oblates of the Virgin Mary in $1816 .{ }^{336}$

332 Emanuele Colombo, "Jesuit at Heart: Luigi Mozzi de' Capitani (1746-1813) between Suppression and Restoration," in Maryks and Wright, Jesuit Survival, 212-28, here 225.

333 Padberg, Colleges in Controversy, 65.

334 Max Heimbucher, Die Orden und Kongregationen der katholischen Kirche (Paderborn: Schöningh, 1908), 103.

335 Diessbach, from a patrician Swiss family with military connections, was an implacable opponent of Josephinian reform and of all things connected to the Aufklärung. Klaus Epstein, The Genesis of German Conservatism (Princeton: Princeton University Press, 1966), 171.

336 Michael Walsh, A New Dictionary of Saints: East and West (Collegeville, MN: Liturgical Press, 2007), 496. 
Paccanari's efforts to create an order on the model of the Jesuits initially gained some powerful supporters, among them Pius VI and Maria Anna of Habsburg-Lorraine (1770-1809), sister of the emperor Francis II, ${ }^{337}$ but the Society of the Faith of Jesus was regarded by others as an unnecessary rival to the "real" Society now based in Russia. Moreover, Paccanari envisioned a female order also based upon Jesuit spirituality, for which he wrote a rule. ${ }^{338}$ For these and other reasons, intense conflict soon developed between Paccanarists and some former Jesuits. Nevertheless, the Paccanarists made overtures to John Carroll (1735-1815), a former Jesuit working in Maryland who in 1789 had helped found Georgetown College (later university). ${ }^{339}$ Carroll was less than enthusiastic regarding the new order's inclusion of a community of nuns, and the Paccanarist proposal produced little, although Peter Epinette (1760-1832) of the Society of the Faith of Jesus did travel to Georgetown and spent the rest of his life in North America. ${ }^{340}$ While Paccanari had little direct impact on the organization and mission of the post-1814 Society, the scandals connected with him provided fresh material for nineteenth-century anti-Jesuit propaganda and thus contributed to the enduring image of the scheming, amoral Jesuit. ${ }^{341}$ The Paccanarian episode also sheds light on the spiritual uncertainty some ex-Jesuit confronted, It also sheds light on the origins of the alliance between reactionary elements of Biedermeier Europe, a period of bourgeois sensibility that lasted from the Congress of Vienna (1814-15) until 1848, and some Jesuits - a relationship that in the long run did the latter little good.

Quebec (Nouvelle France) passed under British rule in 1763, a year before the dissolution of the Society in France. Under the new regime, a few Jesuits

337 Eva Fontana Castelli, "Profezie apocalittiche e identità gesuitica: Niccolò Paccanari e i padri della fede nella Roma di fine Settecento," Dimensioni e problemi della ricerca storica: Rivista del Dipartimento di Storia Moderna e Contemporanea dell'Università degli Studi di Roma "La Sapienza" 1 (2003): 111-30, here 114-15.

338 Phil Kilroy, Madeleine Sophie Barat, 1779-1865: A Life (New York: Paulist Press, 2000), 29. Paccanari had also composed a "Last Warnings of Mary," which was probably a type of spiritual exercise suffused with apocalyptic and counter-revolutionary messages. Fontana Castelli, "Profezie," 123.

339 The ex-Jesuits working in Maryland were known as "The Corporation of Roman Catholic Clergymen." William J. McGucken, The Jesuits and Education: The Society's Teaching Principles and Practice, Especially in Secondary Education in the United States (Eugene, OR: Wipf and Stock, 2008), 59.

340 Hughes, History of the Society of Jesus, 1:815. Epinette had joined the Society of Jesus in 1805 .

341 Such propaganda was only enhanced when Paccanari was misidentified as a former Jesuit in popular anti-Catholic literature. See, e.g., Scipione de' Ricci, Female Convents: Secrets of Nunneries Disclosed, ed. Thomas Roscoe (New York: D. Appleton, 1834), 226. 
remained at their missions, although by 1773 there were only eleven left, at which point the British crown announced that the Society was dissolved and laid claim to all Jesuit properties, although it did not enforce the breve of suppression. ${ }^{342}$ Significantly, Quebec Jesuits do not appear to have been the objects of attacks, unlike their confrères in France-Jansenism had never been a force in North America, and few there had read the writings of the philosophes. In 1774, Lieutenant Governor Hector Cramahé (1720-88) and Bishop Jean-Olivier Briand (1715-94) likewise refused to enforce Dominus ac redemptor. Despite - or perhaps because of - British control of the region, the Jesuits were permitted to keep their name and religious habit and even retained their property; however, they were forbidden to recruit new members and thus their number continued to dwindle. ${ }^{343}$ The French-born Jean-Baptiste de la Brosse (1724-82) continued missionary and educational work after the Society's abolition in France, having thousands of spellers and prayer books in Montagnais printed in 1767. De la Brosse's outstanding literary achievements were the compilation of a census of Montagnais Christians and the completion of a detailed Montagnais grammar that followed the Society's tradition of analyzing languages along Latin models. ${ }^{344}$ One Quebec Jesuit even managed to play a minor role in the American Revolution - on the rebels' side. Father PierreRené Floquet (1716-82) ministered to American forces during the Easter Week of 1776 when they were in Montreal. ${ }^{345}$ For this act, he was placed under interdict by his bishop. By 1789 , only four ex-Jesuits remained, one of whom penned a letter committing their dwelling to "citoyens [a notable choice of words] canadiens" when the fathers were all deceased. ${ }^{346}$ The last of the Jesuits in Canada, the Belgian ${ }^{347}$ father Jean-Joseph Casot (1728-1800), preserved many

342 J.H. [John Hopkins] Kennedy,Jesuit and Savage in New France (New Haven:Yale University Press, 1950), 53 .

343 These guarantees were made in the context of the Quebec Act, passed by the British Parliament in 1774, which gave Catholic French Canadians religious freedom and restored French civil law.

344 Jean-Baptiste de la Brosse, À la recherche d'un signe perdu:Jean-Baptiste de la Brosse, S.J., Éléments de langue montagnaise (1768), ed. Jean-François Cottier and Renée LambertBrétière (Neuville-sur-Saône: Chartae Neolatinae, 2018). Thanks to Florian Schaffenrath for providing this reference.

345 Vincent A. Lapomarda, The Jesuit Heritage in New England (Worcester, MA: Jesuits of Holy Cross College, 1977), 189.

346 Antonio Drolet, "La bibliothèque du collège des jésuites," Revue d'histoire de l'Amérique française 14, no. 4 (1961): 487-544, here 494.

347 According to other sources, Casot was a native of Switzerland. John Lambert, Travels through Canada, and the United States of North America in the Years 1806, 1807, and 1808, 
of the records of the old Society and presented them to the Hospital Sisters of the Hôtel-Dieu before his death.

As a footnote to this saga, the career of Pierre-Joseph-Antoine Roubaud (1724-after 1789) deserves mention if only because he came reasonably close to living up to the caricature of the scheming, amoral Jesuit-although he may never actually have been a member of the Society. A veteran of the Seven Years' War and acquainted with the inside of a debtor's prison, Roubaud was fortynine and apparently an Anglican priest at the time of the suppression, working as a spy for the British. A few years later, he was in the employ of the Spanish ambassador in London, reporting on debates in the House of Commons. Claiming to have been a Jesuit, he unsuccessfully sought to receive a share of the seized properties of the Canadian Society and "disappeared into the slums of Paris sometime after 1789 ."348 Decades later, a landmark court case resulted in a cash settlement returned to the Society to compensate for its losses. ${ }^{349}$

To the south, Jesuits working in the vast Mississippi territory were all expelled, except for the aged father Michel Baudouin (1691-1768), who was allowed to remain behind as the guest of a sympathetic Catholic resident of St. Louis, ${ }^{350}$ and Father Sébastien-Louis Meurin (1707-77), who migrated westward across the Mississippi to St. Geneviève, then in Spanish territory. This arrangement did not last, however, and Meurin ended up swearing allegiance to the British crown and returning to the east bank of the Mississippi and British territory. ${ }^{351}$ Farther upstream, in Illinois country, a few ex-Jesuits carried on as secular priests, with the last survivor, missionary and linguist Pierre-Philippe Potier (Pottier, Pottié, Pothier), dying near Detroit in $1781 .{ }^{352}$

2 vols. (London: Cradock and Joy, 1813), 1:59. Casot was that eighteenth-century rarity, a priest who had begun in the Society as a temporal coadjutor.

348 John Meehan and Jacques Monet, "The Restoration in Canada: An Enduring Patrimony," in Maryks and Wright, Jesuit Survival, 386-98, here 393. Other sources suggest that Roubaud had died sometime earlier.

349 James Rodger Miller, Equal Rights: The Jesuits Estates Act Controversy (Montreal: McGillQueen's University Press, 1979).

$35^{\circ}$ Albert Hubert Biever, The Jesuits in New Orleans and the Mississippi Valley:Jubilee Memorial (New Orleans: n.p., 1924), 62.

$35^{1}$ Daniel Hechenberger, "The Jesuits: History and Impact: From Their Origins prior to the Baroque Crisis to Their Role in the Illinois Country," Journal of the Illinois State Historical Society 100, no. 2 (2007): 85-109, here 101.

352 John Gilmary Shea, Catholic Missions: Among the Indian Tribes of the U.S. 1529-1854 (New York: P. J. Kenedy \& Sons, 1854), 432. 
The suppression severed Jesuits from the life of many regions of the globe, in some cases permanently, but the lingering effects of the old Society's undertakings still appear in surprising places. In Paraguay, where the Jesuits did not return definitively until 1927 , educational attainment remains ten to fifteen percent higher in regions of former Jesuit presence. ${ }^{353}$ Persisting traces of the baroque aesthetic promoted by the Society, spread across the world and exemplified by the theatrical performance witnessed by Goethe and in votive offerings, suggest how the cultural impact of the Society after more than two centuries of prominence was not quickly or easily extinguished.

By contrast, establishing even an indirect causal relationship between the ideas and ethos promoted by former Jesuits and later educational and political developments is not always easy, but the case of Juan Benito Díaz de Gamarra y Dávalos (1745-83) demonstrates a strong connection between these two. ${ }^{354}$ Born in Mexico and trained in Jesuit schools in Mexico and the Philippines, Gamarra journeyed to Italy where he visited former Jesuits and received a doctorate from the University of Pisa. Returning to Mexico, he established a chair of modern philosophy, which at that time still encompassed natural science. Gamarra seems to have been deeply impressed by his encounters with ex-Jesuits even as the scientific models and curricula he developed bore little resemblance to those set forth in the Ratio studiorum.

One Peruvian ex-Jesuit became directly involved in the building storm in colonial South America. Juan Pablo Viscardo y Guzmán (1748-98) wrote to the British consul in Leghorn in 1781, urging his government to support the rebellion led by Túpac Amaru II (1738-81). ${ }^{355}$ Wandering in exile and eventually arriving in England, Visgardo wrote an open letter to the Creoles of his homeland in 1792 in which he denounced the Spanish king as a despot. His posthumously and anonymously published letter, sometimes compared to Thomas Paine's (1737-1809) Common Sense, ${ }^{356}$ influenced many of the leaders of the approaching wars of independence. Viscardo died in London, leaving

353 Felipe Valencia Caicedo, "The Mission: Human Capital Transmission, Economic Persistence, and Culture in South America," Quarterly Journal of Economics 134, no. 1 (2019): 507-56.

354 Enrique Villalba Pérez, Consecuencias educativas de la expulsión de los jesuitas de América (Madrid: Editorial Dykinson, 2003), 45.

355 Charles F. Walker, The Tupac Amaru Rebellion (Cambridge, MA: Harvard University Press, 2016), 290.

356 Lettre aux Espagnols américains: Par un de leurs compatriotes (Philadelphie [London], 1799). 
his papers to Rufus King (1755-1827), the American minister to the Court of St. James. ${ }^{357}$ Remembered as a "precursor of independence" in Latin America, Visgardo's actions were highly individualistic and are difficult to correlate with ether his Jesuit foundation or the activities of his fellow ex-Jesuits. Perhaps the strongest links to the old Society are found in his willingness to take risks and flare for sustained polemic.

A few former Jesuits kept alive the polemical and rhetorical traditions of the Society even while events took unanticipated turns. Juan José Tolrá (1739-1830), perhaps emboldened by the fluid situation in Spain brought on by the departure of Joseph Bonaparte (r.18o8-13), published an attack on the Pragmática de expulsión that had suppressed the Society there in $1767 .^{358}$ Citing the upheavals brought to Italy by revolutionary French troops, Tolrá argued for the restoration of throne and altar, an ideology that the nineteenth-century Society would often support, but his rhetorical style, although expressed in the vernacular, betrays a connection to the older Latin models taught in the schools of the Society. Taking a very different position from Dobrovský, who sought to debunk the Jesuit-promoted legend of St. Jan Nepomucký, in a massive tome Tolrá defended the doubtful tradition that St. James had journeyed to Spain and was buried there. ${ }^{359}$

Ex-Jesuits thus presented many faces in the debates and conflicts arising in the decades after 1773. Not only is it impossible to generalize about an ex-Jesuit "way of proceeding," but the unified impact of Jesuit formation on some of the most original thinkers among these men is doubtful. Far from being soldiers in a vast conspiracy driven by a determined and crafty leadership, former Jesuits exhibited a variety of motives and capabilities. From Wendel to Carroll to Blumauer to Dobrovský to Visgardo, ex-Jesuits can come across as individuals inhabiting at times very different moral and intellectual universes.

357 Merle Edwin Simmons, Los escritos de Juan Pablo Viscardo y Guzmán, precursor de la independencia Hispanoamericana (Caracas: Universidad Católica Andrés Bello, 1983), 15.

$35^{8}$ Juan José Tolrá, Reclamación de tres ex-jesuitas españoles residentes en la península (Vic: En la oficina de Juan Dorca, á expensas de algunos apasionados á los ex-jesuitas, 1813).

359 Juan José Tolrá, Justificación histórico-crítica de la venida del apóstol Santiago el Mayor á España (Madrid: Impr. de la viuda de Ibarra, 1797). 
On August 7,1814, only two months after his return to Rome from exile, Pius VII signed the bull Sollicitudo omnium ecclesiarum that restored the Society. ${ }^{360}$ The title of the bull was taken from Paul's Second Epistle to the Corinthians: "I face daily the pressure of my concern for all the churches,"361 therein articulating the argument for the restoration of the Society in terms of its service to existing Catholic communities rather than in feats of exploration, achievements of scholarship, or even evangelization. Indeed, missionary work is not even mentioned in the pope's bull. The distance from the earlier Jesuit ethos is striking: one world, and that a smaller one than before, was now more than enough. If the breve suppressing the Society had illustrated the weakness of the papacy, the bull restoring the Jesuits said much about the increasing confidence of at least this particular pope leading the post-Napoleonic church. Pius VII established new dioceses in the United States and enjoyed the (at least temporary) support of European monarchs, something Clement XIV had never gained. Yet the continuing vulnerability of the nineteenth-century papacy and the growing indifference with which much of the world viewed its pronouncements were both significant features of the environment in which the restored Society would have to work. The number of actual Jesuits ready in 1814 to resume some portion of the role the Society had previously played was very small: probably no more than six hundred, based mostly in Europe. These factors have shaped the way historians working during the nineteenth and much of the twentieth centuries have dealt with the years of suppression.

Our understanding of the Jesuit experience between 1773 and 1814 has gained subtlety in recent years in part because of the flurry of scholarship accompanying the bicentennial of the Society's restoration. Increased interest in missionary studies and in cross-cultural contacts has also contributed greatly to our understanding of this period, as has the "decentering" of a previously Eurocentric narrative. Instead of merely being labeled a "period of suppression," the decades following Dominus ac redemptor now appear as a time of restricted, yet, in some ways, real continuity, of regeneration, and even of growth and innovation. Intertwined with these processes were the careers of individual former Jesuits who in some cases did not follow the same professional or

360 The entire Latin text, with a French translation, appears in Bulle Sollicitudo omnium ecclesiarum du o7 août 1814 Pie VII (Lyon: M.-P. Rusand, 1814), and with an English translation in McCoog, Promising Hope, 322-30. The implementation of this bull was not immediate: in Spain, all restrictions on the return of the Society were not lifted until June 1, 1816.

$361 \quad 2$ Corinthians 11:28, New International Version. 
spiritual paths that had characterized their identities as Jesuits. For example, Karl Leonhard Reinhold (1757-1823), cut loose from the Society at the age of sixteen, became a Barnabite monk and then converted to Protestantism (with an interlude as an illuminist), going on to contribute to the literature of postKantian idealism. His relations with the Masons and his contributions to the theory that Moses was an Egyptian mark Reinhold as one of the most adventurous of former Jesuits. ${ }^{362}$

The verdict is still out on whether the Jesuit tendency at times to accommodate new political arrangements was ultimately more of a help or hindrance to the Society during these years. In Russia, this adaptability made survival possible until the expulsion of 1820. In Manila, when the British fleet arrived in 1762 (during the Seven Years' War) and looting of the city followed, Jesuits took down the Spanish flag and replaced it with the British, which surely did not help their case when Carlos III began to contemplate their expulsion a few years later. ${ }^{363}$ Yet Jesuit adaptation to conditions in the United States helped make the decades after 1814 generally successful ones for the Society. 364

Long focused on the political process of suppression and restoration, scholars are now attending to the human consequences of the Society's suppression. Many, perhaps most ex-Jesuits, whatever their new roles, experienced bewilderment and uncertainty, sometimes tinged with anger, which could lead them to act in concert as a "new Jesuit International." 365 The surrendering (sometimes to rival religious orders, other times to oblivion) of missions and other undertakings to which they had devoted their lives was deeply painful for many ex-Jesuits. Others such as Dobrovský, traveling in new directions that built upon the scholarly or technical aspects of their Jesuit training, do not seem to have looked back. And not a few disappeared from the record, never to be heard from again. The suppression's impact on laypeople was significant,

362 Jan Assmann, Moses the Egyptian (Cambridge, MA: Harvard University Press, 1997), $115^{-17}$.

363 Francis B. Galasi, "Jesuits in the Philippines: Politics and Missionary Work in the Colonial Setting," (MA thesis, CUNY City College of New York, 2014), 50; https://academicworks .cuny.edu/cc_etds_theses/539/(accessed July 2, 2019).

364 The perhaps inevitable tensions between foreign-born and native-born Jesuits at Georgetown was made more complicated by the personalities and skills (or lack thereof) of some of the community's leaders, such as Louis W. V. Dubourg (1766-1833), who was president of Georgetown from 1796 to 1799. See Robert Emmett Curran, A History of Georgetown University, 3 vols. (Washington, DC: Georgetown University Press, 2010), 1:52-55, 70 .

365 Dale K. Van Kley, "Catholic Conciliar Reform in an Age of Anti-Catholic Revolution," in Religious Differences in France: Past and Present, ed. Kathleen P. Long (Kirksville, MO: Truman State University Press, 2006), 91-140, here 113. 
and not merely because Jesuit schools ceased to exist. Not only was a career path for young men of many social origins now blocked but sodalities and other organizations that had provided meaning and contexts for socialization disappeared or were now run by clergy with much different backgrounds and objectives. Most importantly, the surviving sodalities no longer had the unique and powerful Spiritual Exercises as a source of spirituality. ${ }^{366}$

Thanks to scholars such as Dale Van Kley, the cultural and intellectual climate both within and beyond the Society in the years before the suppression is also receiving a fresh look. The anachronistic tendency to view the issuance of Dominus ac redemptor as a precursor to a secular, anti-clerical French Revolution that may now seem inevitable has been counterbalanced by a better understanding of the motives of those within the Catholic Church who wanted to restore and purify, rather than destroy the Society. Far from being merely the result of efforts of those seeking a more secularized path toward modernity, the papal breve was also driven by deeply conservative forces as well, eager to preserve a gradually evolving status quo where monarchy and privilege were secure. In this scenario, personalities within the Society could be seen as a destabilizing force (Malagrida comes to mind), rather than as natural allies of the ancien régime. The declining power and influence of the Society's historic rivals, from Jansenists to Dominicans, must likewise be kept in mind. The end of the old Society was less the result of a coordinated conspiracy than of a perfect storm.

The forty-one years between the promulgation of Dominus ac redemptor and that of Sollicitudo omnium ecclesiarum were extraordinarily eventful ones for world history. The American and French Revolutions, the Napoleonic era, the advance of the Industrial Revolution, the growth of Russian power, and the beginning of the end of the Spanish and Portuguese Empires in the Western Hemisphere and the advance of French and British Empires in the Eastern were all realities confronting the restored Society. The papacy had also passed through the nadir of its influence and, perhaps more importantly, its credibility as a spiritual force, and this experience would shape its dealings with the restored Society. An equally significant trend was the continued rise in the West of an empirical and theoretical science generally inimical to the goals and approaches of the pre-suppression Society. A far less confident Society would concentrate more on institution-building and internal affairs

366 Robin Maas and Gabriel O'Donnell, Spiritual Traditions for the Contemporary Church (Nashville: Abingdon, 1990), 184. 
than on scholarship or data collection as it tried to adjust itself to this new world. ${ }^{367}$ The expulsion of the Society from St. Petersburg by Alexander I only sixteen months after Sollicitudo omnium ecclesiarum presaged the challenges that lay ahead.

As Niccolò Guasti points out, a major project of the pre-1773 Society in Europe had involved reconciling Thomism with the onslaught of new ideas flooding into philosophy and the sciences, a program he calls "Ignatian syncretism." ${ }^{368}$ By 1814 , very few intellectuals outside of strictly Ultramontane circles had any interest in such an undertaking. Books such Muzzarelli's that criticized Rousseau and Romantic ideas had a considerable lay audience, but typically not one consisting of influential thinkers and educators. The centers of gravity of discourse in both the sciences and the humanities had shifted and continued to shift, and no amount of effort by the restored Society could make a project focusing so much on Thomism important again. The suppression itself contributed little to this shift, but the restored Society, in addition to its many other challenges, found itself distanced from new debates regarding, for example, utilitarianism, which dominated philosophy in the nineteenth century.

After 1814, not merely the material resources of the Society were restricted but likewise the vision with which many Jesuits understood the work before them had also grown narrower. Had the years of suppression not seen the excesses of the French Revolution, this narrowing of vision might have been less extreme, but the origins of this process may be found many years before Dominus ac redemptor. What John W. O'Malley calls the "tired and defensive formalism"369 of the restored Society had its genesis in the bruising years following the Chinese Rites Controversy, gained gravity during the suppression through the alliance of former Jesuits with ultra-conservative political and religious figures, and was strengthened during the reactionary pontificates of Gregory XVI $\left(1765^{-1846}\right.$, r.1831-46) and Pius IX (1792-1878, r.1846-78). Significantly, the restored Society, still largely made up of Europeans, did not try to re-establish universities in Europe and instead sought to restart its mission in higher education on other

367 John T. McGreevy, "Restored Jesuits: Notes toward a Global History," in The Jesuits and Globalization: Historical Legacies and Contemporary Challenges, ed. Thomas Banchoff and José Casanova (Washington, DC: Georgetown University Press, 2016), 131-46, here 131.

368 Niccolò Guasti, "The Exile of Spanish Jesuits in Italy (1767-1815)," in Burson and Wright, Jesuit Suppression, 248-61, here 254.

369 John W. O'Malley, "How Humanistic Is the Jesuit Tradition? From the 1599 Ratio studiorum to Now," in Jesuit Education 21: Conference Proceedings on the Future of Jesuit Higher Education 25-29 June 1999, ed. Martin R. Tripole (Philadelphia: St. Joseph's University Press, 2000), 189-201, here 196. 
continents. ${ }^{370}$ Thus did the origins of the increasingly internationalist Society of the twenty-first century take root.

The suppression thus caused a break in not merely the geographical (and thus, indirectly the cultural) focus of Jesuit higher education but also in the goals of Jesuit universities and of Jesuit education more generally. Schools located in the United States or Brazil needed to adapt to vastly different political and social arrangements from those found in pre-1773 Europe, among them competition from other universities and opponents or competitors who were much better organized than they had been in the previous century. Aggressive proselytizing was out of the question in many of these venues. Some of the battles the restored Society had to fight had familiar contours, but in the broader cultural context, Jesuits often found themselves on the opposite side from innovative scholarship, modern science, applied technology, and creative theology. Surveying this shift, the historian is tempted to wonder whether the restored Society now received a significantly different group of self-selected men as its members, their choices driven by frustration and anger with the blows suffered by the Catholic Church, by doubts about the new political and economic order, or by other motives not yet identified. Yet the restored Society also produced such inspired characters as Pierre-Jean De Smet (1801-73), whose energy and initiative rivaled that of the most remarkable Jesuits of earlier times. The mystique of the Jesuits, it seems, could not be completely extinguished by the restored Society's hardships and failures.

While we have noted the significant number of scholarly and scientific works that were composed by Jesuits in the Western Hemisphere before their expulsion, there remain a number of unpublished manuscripts the study of which will undoubtedly add to our understanding of the period immediately before the suppression. Representative of this literature is the Historia natural del Orinoco (Natural history of the Orinoco) of Antonio Salillas (1717-90), which remains in a Madrid archive. ${ }^{371}$ In India, Fr. Joseph Tieffenthaler (1710-85) had composed more than forty short works, none of which has ever been located. Also unaccounted for are manuscripts of the English-born Jesuit surgeon Thomas Falkner, who spent thirty-eight years in South America and published a description of Patagonia. ${ }^{372}$ The manuscripts of Pierre-Phillipe Potier, whom we have already met, dealing with the Huron language have been identified but have yet to be edited or published. Likewise, Historiae domus (History of

370 Grendler, Jesuits and Italian Universities, 444.

371 José del Rey Fajardo, Los jesuitas en Venezuela: Las misiones germen de la nacionalidad (Caracas: Universidad Católica Andrés Bello, 2007), 471.

372 Thomas Falkner, A Description of Patagonia, and the Adjoining Parts of South America (Hereford: C. Pugh, 1774). This book is a compilation made by William Combe (1742-1823) of Falkner's writings. 
the [Jesuit] house), Diaria (Diaries), and other "internal documents" of communities of the pre-1773 Society have yet to be analyzed for clues they could provide about the years of suppression, as are as of yet undiscovered letters by former Jesuits.

When considered individually, the careers of ex-Jesuits show the importance of networks and relationships established long before 1773, but also the capacity of some of these men to function effectively with seemingly very little support. The origins of both these traits can be found in the old Society, where lines of communication and authority were firm but where individual initiative, flexibility, and persistence were likewise essential for survival. The remarkable endurance of ex-Jesuits in India and China is due in part to the self-selection process by which men who had "sought the Indies" eventually arrived at these distant and challenging assignments. Indeed, research into the post-suppression Society has revealed both patterns and continuities among individuals and groups, but also strikingly diverse paths in the cases of some of these men. And had Jesuits not been expelled from South America, this survey might have included accounts of equally exceptional post-1773 careers of former Jesuits on that continent as well.

Surveying the lives of Jesuits still in their prime at the moment of expulsion or suppression, one is struck by the number of priests, including those who had held important posts, who simply vanished from sight, although they lived on for many years. Joseph Ernst Mayer (1752-1814), who became the director of the Philosophical Faculty of the University of Vienna in 1786, disappears from the record during the turbulent period following the defeat of the Austrians by Napoleon in $1809 .{ }^{373}$ Iberian Jesuits tended to fare worse than their Habsburg or Polish counterparts, with those who labored in the Western Hemisphere facing the worst fates. José Sánchez Labrador (1717-98), expelled from Paraguay in 1767 after a distinguished career as a naturalist and explorer, lived in Ravenna for the next quarter century but almost nothing is known of these years. ${ }^{374}$

The role and prominence of temporal coadjutors in the restored Society also reflected changing times. While devout men continued after 1814 to choose the vocation of lay brother, the function of these Jesuits as intermediaries between Jesuit priests and the communities in which they worked was reduced in importance. The Society now owned far fewer large tracts of land and less frequently supervised the running of large metropolitan churches, two settings

373 Born in 1751, Mayer does not appear in a list of scholars who died between 1800 and 1810 and is never heard from subsequently. Constant von Wurzbach, Biographisches Lexikon des Kaiserthums Oesterreich, 61 vols. (Vienna: Zamarski, 1868), 18:147. 
in which temporal coadjutors had served as bookkeepers, pharmacists, musicians, and furniture-makers, among other functions. Jesuit brothers had also provided much of spiritual bedrock of the old Society, but it is less clear whether this was also their role in the nineteenth century. The emergence of the bourgeoisie in nineteenth-century Europe meant that the late feudal social arrangements that had obtained when the first Jesuit brothers had joined the Society were no longer universally dominant, a change that surely affected vocations. Much work remains to be done on the lives of these men after $1773 .{ }^{375}$ In a similar vein, the experiences of spiritual coadjutors (coadjutores spirituales), Jesuit priests whose responsibility had been the "care of souls" rather than scholarly or scientific achievement, have been underreported in accounts of the suppression that have been dominated by published sources focusing on the achievements of Jesuits "of the fourth vow."

While the expulsions and suppression of the Society were acts initiated in Europe, the worldwide context in which events played out is now being explored from a perspective less consciously Euro-centric, a trend that reflects a worldwide tendency in our understanding of ecclesiastical history. The suppression of a religious order that has been called the "world's first multinational corporation"376 triggered a series of events that could not have been foreseen by any of the players. The case of Lorenzo Hervás y Panduro (1735-1809), as a chronicler of the fortunes of ex-Jesuits, is a case in point. ${ }^{377}$ Born in Spain, Hervás y Panduro arrived in Italy with his exiled brethren in 1767 and remained there for thirty-eight of the remaining forty-two years of his life. Among the works he completed during this sojourn was a monumental study of the languages of the world from which he intended to construct an overarching theory of ethnology. The conclusions that Hervás y Panduro drew concerning, for example, Romany are not regarded as correct today. However, his undertaking represents a carefully documented attempt to draw together data on languages as diverse as Kurdish and Vietnamese and as such is an example of how Jesuit baroque universalist ideology persisted as well as an instance of painstaking data collection, collation, and comparison for which the pre-suppression

375 See Hermann Haberzettl, Die Stellung der Exjesuiten in Politik und Kulturleben Österreichs zu Ende des 18. Jahrhunderts (Vienna: Verband der Wissenschaftlichen Gesellschaften Österreichs, 1973), 133; Paul Shore, The Eagle and the Cross: Jesuits in Late Baroque Prague (St. Louis, MO: Institute of Jesuit Sources, 2002), 229. For the fates of two English temporal coadjutors stranded in Bruges, see Whitehead, English Jesuit Education, 102.

376 Charles Ralph Boxer (1904-2000), cited in Fred Vermote, "Finances of the Missions," in A Companion to Early Modern Catholic Global Missions, ed. Ronnie Po-chia Hsia (Leiden: Brill, 2018), 367-400, here 368 .

377 Caruana, "Legacies," in Burson and Wright, Jesuit Suppression, 271. 
Society was so renowned. But Hervás y Panduro's project was in some ways a throwback and one of the last of its kind ever attempted by a Jesuit.

The significance of the suppression and the years that followed is highlighted in some readily identified differences between the eighteenth- and nineteenth-century Societies. The restored Society was made up almost entirely by a new generation of Jesuits, many of whom had grown up in the difficult years of Napoleonic domination of Europe. Added to this, the restored Society found itself in a political setting unlike the one it had previously known. The emerging nation states of Germany and Italy-and the nationalistic passions that accompanied their emergence - the expansion of a new wave of European colonialism, the reconstitution of the Habsburg monarchy on a non-sacramental basis, and the firm and final rejection by the Orthodox world of any further unions with Rome all placed Jesuit educational and missionary efforts in a far less certain position than before. During the French Revolution and Napoleonic era, Europe had endured a prolonged period of uncertainty that raised expectations among some for even greater change while producing fear and anxiety for others. One of the first acts of liberal nineteenth-century revolutions was the expulsion of the Society.

The colonial powers Spain and Portugal, always centers of Jesuit activity, were now greatly diminished. Moreover, the arguments that had sustained Jansenism for several centuries in its attacks on the Society were now retooled for the quarrel between Ultramontane and Gallican views of the church, a battle fought in a very different context. ${ }^{378}$ Each of these factors drew some exJesuits in new directions from those of Jesuits of the previous centuries.

Perhaps most importantly, the reactionary and at times fearful posture of a beleaguered Holy See to which the Society continued to offer its obedience put the Jesuits, in the view of many Catholics and non-Catholics, on the side of forces holding back progress. Yet through all this Jesuit institutional memory preserved a sense (at times mythologized) of the pre-suppression Society and provided a sense of continuity through a difficult period that has been called the time of the "second Society of Jesus." While it may be easy to draw a distinction between the "new" and "old" Societies, the experiences of individual ex-Jesuits varied greatly and included those who never lost hope in the restoration of the Society and understood the suppression as a time of trial that would be successfully endured.

378 Thomas Worcester, "Pius VII: Moderation in an Age of Revolution and Reaction," in The Papacy since 1500: From Italian Prince to Universal Pastor, ed. James Corkery and Thomas Worcester (Cambridge: Cambridge University Press, 2010), 107-24, here 113. 
One outcome of the years of suppression was the almost complete extinction of the baroque aesthetic (including its manifestations in homiletics), and its predilections for the eclectic, emotional, and exotic that had lingered in many corners of the Jesuit world until a little past $1773 .{ }^{379}$ While this aesthetic had passed out of fashion in Western and Central Europe many years earlier and its demise may be regarded as inevitable, the suppression, and the destruction and dispersion of libraries and art collections that followed, produced a clear break with the baroque, and the years that followed imposed a distance that made any return unlikely. ${ }^{380}$ In Brazil, the tropical climate triggered the accelerated physical decay of books from Jesuit libraries, which became another factor hastening the loss of examples of this baroque aesthetic, and perhaps with it a baroque spirituality. ${ }^{381}$ Nineteenth-century opinion at first saw these developments as no loss at all, as it regarded the baroque as debased, and often blamed the Jesuits for this debasement, an assessment that was only challenged effectively in the twentieth.

Unlike its predecessor, the restored Society proved to be champion of no readily discernible artistic or dramatic style nor of an identifiable approach to library science, poetry, music, or historical methodology, facts that remain true today. Likewise, the restored Society was less daring and innovative in its exploration of the spiritual. The relative poverty of the nineteenth-century Society may have contributed to these deficits, but a much greater factor was the gap in institutional memory brought on by the Suppression. Many of the day-to-day records of the old Society had been either destroyed or scattered, and thus were inaccessible to the men trying to reconstruct the order after 1814. The loss of these records contributed to the formalism we have already mentioned, since the lived experience of earlier Jesuits was not always visible in the formulaic published hagiographies and "annual letters" to which the restored Society had to turn for models. Yet in the former Spanish colonies of the Western Hemisphere, Jesuit baroque historiography proved adaptable,

379 Traces of the baroque lingered in the more remote corners of what had been the Jesuit universal enterprise: a map of southern Chile accompanying the description by ex-Jesuit Bernhard Havestadt (1714-81) of missions of that region includes an asymmetrical cartouche, a tabernacle over an altar, and other baroque details. Chilidúgǵú, sive Res Chilienses [...] opera [...] Bernardi Havestadt [...] (Münster: Typis Aschendorfianis, 1777).

380 A few structures designed by Polish ex-Jesuits in the by now very old-fashioned baroque style were completed shortly before 1780 . Paul Shore, "Ex-Jesuits in the East Habsburg Lands, Silesia, and Poland," in Burson and Wright, Jesuit Suppression, 229-47, here 244.

381 Mark L. Grover, "The Book and the Conquest: Jesuit Libraries in Colonial Brazil," Libraries \& Culture 28 , no. 3 (1993): $266-83$, here 279 . 
transforming itself into "the critical idiom of enlightened natural philosophy,"382 which was employed to defend the South American continent and its peoples from the unflattering portrayal given them by some European authors. 383

Among the ex-Jesuits who remained active after 1773 were hydraulic engineers, ${ }^{384}$ architects, horticulturists, ${ }^{385}$ fortification designers, and even educators in maritime studies. ${ }^{386}$ The post-1814 Society was not entirely without such talent, but there was no emphasis in Jesuit schools on applied mechanical training, nor did Jesuits parley their skills in these areas into positions of influence in government or education. While this shift was not much remarked upon at the time, it now appears as a significant development in the history of the Society, not least because it illustrated yet another retreat from an earlier engagement with quantitative studies and practical application of knowledge. Although earlier Jesuits such as Athanasius Kircher (1602-80) had speculated about the inner structure of the earth, ${ }^{387}$ Jesuits and ex-Jesuits played no role in the revolution in geology that commenced in the early nineteenth century. Perhaps most significantly, given the old Society's long engagement with drama, the golden age of German Romantic drama could claim no successors to Anton von Klein (1746-1810), who spent decades after the suppression

382 Andrés I. Prieto, "Jesuit Tradition and the Rise of South American Nationalism," in Maryks and Wright, Jesuit Survival, 399-414, here 414.

383 Representative of this genre is the Essay on the Natural History of the Gran Chaco ... (1789) by Giuseppe Jolis (1728-90). See Antonello Gerbi, The Dispute of the New World: The History of a Polemic, 1750-190o, trans. Jeremy Moyle (Pittsburgh: University of Pittsburgh Press, 1973), 218. See also Francisco Javier Clavijero, Historia de la Antigua o Baja California, trans. Nicolás García de San Vicente (México: Porrúa, 1970); and Giovanni Antonio Coleti, Dizionario storico-geografico dell'America Meridionale (Venice: Stamperia Coleti, 1771), which in organization and tone owes something to the Encyclopédie of Denis Diderot (1713-84).

384 Among these was Michel Benoît (1715-74), who had designed a fountain for the Imperial Chinese Summer Palace and died weeks before word of the Society's suppression reached China. Stefan Halikowski Smith, Creolization and Diaspora in the Portuguese Indies: The Social World of Ayutthaya, 1640-1720 (Leiden: Brill, 2011), 159.

385 Franz von Paula Schrank (1747-1835) wrote dozens of works on natural history and in 1809 became director of the Munich Botanical Gardens. Jonathan Wright, "From Immolation to Restoration: The Jesuits, 1773-1814," Theological Studies 75, no. 4 (2014): 729-45, here 735 .

386 Francis Xavier Orlando, a native of Rijeka (d.1784), founded a School of Nautical Studies in the city that he directed until his death. "The Library of Jesuit College in University Library Rijeka”; https://svkri.uniri.hr/digitalno/files/original/Izlo_ba_plakata_na_Korzu/ Plakati.pdf (accessed July 2, 2019).

387 Mark A. Waddell, Jesuit Science and the End of Nature's Secrets (New York: Routledge, 2016), 245 . 
producing plays in the vernacular. ${ }^{388}$ Taken together with the rearguard actions some Jesuits would fight on behalf a papacy resisting social change, this withdrawal from the natural and applied sciences marks an important break between the cultures of the pre-1773 and the restored Societies.

Some commentators have suggested that the years of suppression liberated Jesuits from the structures of approval and promotion that had characterized the Society in its heyday. Such claims are not easily tested, but viewed through the prism of Christian theology, this notion can shed light on the subsequent evolution of Jesuit spirituality and even on the Society that emerged in the mid-twentieth century, with its "preferential option for the poor" and its engagement with liberation theology. Pope Francis (1936-, r.2013-), himself a Jesuit, has gone further, suggesting that Lorenzo Ricci's attitude toward the suppression, as emulated by other Jesuits, "led the Jesuits to experience the death and resurrection of the Lord." ${ }^{389}$ Certainly the four decades of suppression added to the lore of a religious order that has always celebrated stories of its trials and martyrs.

The suppression compelled Jesuits to reflect on their mission and identity, both collective and individual. For some, obedience to the papacy to the point of accepting the destruction of their corporate (and in many cases, personal) identity was evidence of their own piety ${ }^{390}$ while others privately- or not so privately — criticized ${ }^{391}$ Clement XIV. The loss of a centralized and universally recognized hierarchy for the Society outside of the White Russian communities meant that expressions of "Jesuit spirituality" might take various and even

388 Von Klein produced German drama and poetry and translated a work by Pietro Metastasio (Antonio Domenico Trapassi [1698-1782]) into German. He was ennobled in 179o. Karl Krükl, Leben und Werke des elsässischen Schriftstellers Anton von Klein (Paderborn: Salzwasser Verlag, 2015).

389 James Martin, "Pope Francis' Address to the Jesuits on the Anniversary of Their Restoration," America (September 27, 2014); https://www.americamagazine.org/faith/2014/09/27/ pope-francis-address-jesuits-anniversary-their-restoration (accessed July 2, 2019).

390 The last pre-suppression superior general, Lorenzo Ricci, was imprisoned in the Castel Sant'Angelo, where he died in 1775. Ricci's steadfastness and suffering earned him the reputation of martyr among supporters of the Society. Campbell, Jesuits, 583 .

391 Former Jesuits supervised the publication in Rome of Gazzetta ecclesiastica, which made insinuations regarding Clement's character and actions. Samuel J. Miller, Portugal and Rome c.1748-1830: An Aspect of the Catholic Enlightenment (Rome: Università Gregoriana Editrice, 1978), 303. Giuseppe Maria Carafa (1717-86), the bishop of Trivento, responded with an anonymous refutation of the Gazzetta in his Confutazione della Gazzetta ecclesiastica francese: Circa un' operetta stampata in Roma (Livorno, 1781). Clemente Bondi (1742-1821) composed a poetic attack on the pope that attracted considerable attention. [Vincenzo Gioberti], Vita di Fra Lorenzo Ganganelli, Papa Clemente XIV: Nuova edizione (Italia [sic], 1847), 262. 
competing forms. A few ex-Jesuits turned to prophecies of, for example, the return of the Society to Spain.

Geography, ethnicity, great power politics, and occasionally chance resulted in vastly different experiences for various communities of ex-Jesuits. Those of the Portuguese Empire probably fared worst of all, lacking champions and subject to an especially repressive and vindictive regime. The experience of Jesuits in Russia was colored by the fact that virtually all were non-Russians and remained representatives of a religion not associated with a dominant or even sizeable ethnic group or language. By contrast, the native-born ex-Jesuits of Hungary, Bohemia, Austria, and Poland became journalists, curriculum reformers, and parish priests. Jesuits in India seem to have endured through their faith, their wits, and their frequently highly homed linguistic skills. In addition to the spiritual aspects of the divisive Paccanari episode, former Jesuits sought to perpetuate a distinctly Jesuit spiritual life in other ways, although in a few instances, the paths they followed were far from those that had been set out by Ignatius. ${ }^{392}$ The pre-suppression Society had always included men who tested the limits of obedience and who could be largely solitary and even contrarian figures. The suppression years accentuated these tendencies as exJesuits searched for paths to follow in an unfamiliar and often hostile environment. Even allowing for their advanced age, that so few former Jesuits from the European continent joined the restored order after 1814, or engaged with it in any way, is a notable fact that merits more investigation. ${ }^{393}$

The restored Society was not compelled to start over completely from scratch, but its growth was slow and cautious, and after half a century it had only reached a third of the size it had been in 1773, with far fewer resources and political connections at its disposal. Thus, although the suppression ended in 1814, its impact continued, with the students of Jesuits who taught during these first "lean years" carrying the sensibilities of the immediately post-suppression Society far into the nineteenth century - and in some quarters, even further. Two hundred years later, the institutional memory of the Society retains a recollection of the hardships, and in the view of many Jesuits, injustices experienced in the years after 1773 .

392 Brian O'Leary, "Jesuit Spirituality before and after the Suppression," Studies: An Irish Quarterly Review 103, no. 412 (2014/15): 586-97. Not enough is yet known about the role of the Spiritual Exercises in the devotional lives of many ex-Jesuits.

393 The situation was different in both the English province and in Maryland. See Geoffrey Holt, "The English Province: The Ex-Jesuits and the Restoration," and "The English ExJesuits and Jesuits and the Missions 1773-1814," in McCoog, Promising Hope, 219-58, here 254-55, and 177-90. 
William Clark observes that Jesuits of the pre-1773 Society (perhaps including Father Luengo Rodríguez, whom we have already met) had no private life, in the modern bourgeois sense of the word, as they gave themselves entirely to the Society. ${ }^{394}$ It is less clear that the men of the restored Society always constructed their identities in the same fashion. Obedient to a papacy frequently on the defensive and facing an environment where they could be frequently expelled from countries on short notice, some of the survivors of the suppression turned to their corporate identity at a point when that identity was being reconfigured or in doubt. Simultaneously, they could be drawn into polemics and politics in which their identities, both as Jesuits and as individuals, might be the object of public ridicule or contempt. ${ }^{395}$ In the nineteenth century, no immensely powerful Society stood at their back to defend and protect these men. The tensions set loose by this process moved some Jesuits toward a reactionary view of post-1814 (or even post-1789) politics and society, a trend that can be called a secondary effect of the suppression. With such facts in view, the question of essential continuity between the pre- and post-suppression Societies can be raised.

Without wading too far into the shoals of alternative history, we can see the impact that the suppression had on world history more generally. Dominus ac redemptor eliminated the most conspicuous target of those seeking to replace the Catholic theological ideologies as articulated in the struggles of the seventeenth century with a rationalist, mechanical, and materialist worldview. But the suppression of the Society did not destroy the desire in many quarters to turn to the miraculous and transcendent symbols and experiences of baroque Catholicism to cope with change and modernity. The nineteenth-century fusions of national and ethnic passions with traditional Catholic belief, from the movement of Andreas Hofer (1767-1810) in the Tyrol to the rebellion of Louis Riel (1844-85) on the Canadian prairies, are evidence of this persisting desire. The factors that shaped world Catholicism in the nineteenth and twentieth centuries were in fact transformed by neither the Society's suppression nor by its restoration. It should also be recalled that the downfall and suppression of the Jesuits took place as other Catholic orders, including their rivals the Dominicans, were also in significant decline, a process that the Napoleonic era

394 William Clark, "The Pursuit of the Prosopography of Science," in The Cambridge History of Science, vol. 4, Eighteenth-Century Science, ed. Roy Porter (Cambridge: Cambridge University Press, 2003), 211-37, here 218.

395 Geoffrey Cubitt, The Jesuit Myth: Conspiracy Theory and Politics in Nineteenth-Century France (Oxford: Clarendon Press, 1993), 59. 
would accelerate. ${ }^{396}$ Thus in many of its most dramatic aspects the suppression was more a part of than at odds with broader developments in Catholicism.

The break between advancing empirical science and the activities of the Society likewise was probably inevitable, even if the suppression had not taken place. The resources required for scientific research were increasingly beyond the means of a Society simultaneously committed to recovery and to missionary and educational projects. The growing antipathy of some Western scientists toward a theistic worldview was increasingly a feature of nineteenthcentury intellectual life, whether or not Jesuits were part of the conversation. Jesuit obedience to a papacy that had not yet acknowledged Galileo's contributions, let alone subsequent scientific advances, remained a huge stumbling block. The parting of the ways between the Society and the major universities of Europe and the Jesuits' initial lack of strong connection to emerging research universities in the United States sealed the deal. All the same, seen from a distance of two centuries, it is clear that the interruption in the lives and careers of many Jesuit scientists deprived many fields of study of needed talent.

The story is different in the field of pre-university schooling. The reestablishment of Stonyhurst College in 1794, by ex-Jesuits fleeing from Liège, is representative of the most successful secondary programs developed by the restored Society. ${ }^{397}$ The removal of Jesuits from many universities, a process that began before 1773, occurred simultaneously with the reform of many European universities, a process not limited to Catholic ones. ${ }^{398}$ The Society had always been concerned with what would later be known as secondary education, but in the years after 1814 the distinction between secondary and higher education became much greater in many Western countries, and Jesuits responded to these circumstances by focusing their energies on the training of adolescent boys. The result was the development of an outstanding network of secondary schools that helped secure the Society's reputation at a point when its presence in European and American universities and research centers was at a low

396 Between 1700 and 1780 , owing to both a general decline in vocations and the suppression of the order in many countries, the Dominicans lost one-third of their numbers. Bertrand M. Roehner, "Jesuits and the State: A Comparative Study of their Expulsions (1590-1990)," Religion 27, no 2 (1997): 165-182, here 168; doi: 10.1006/reli.1996.0048 (accessed July 2, 2019).

397 Whitehead, English Jesuit Education, 1.

398 Willis Rudy, The Universities of Europe, 1100-1914: A History (Rutherford, NJ: Fairleigh Dickinson University Press, 1984), 79-99. 
ebb. Since the Society's first school had educated young boys in Renaissance Messina, ${ }^{399}$ a significant element of Jesuit education had now come full circle.

For many years after 1773, hostile commentators saw the suppression as part of an inevitable and salutary process of decline for the Catholic Church, and perhaps for all organized religion. Many of those sympathetic to the Society saw its restoration as a reaffirmation of the superior values of the ancien régime: order, deference, and tradition. While both interpretations are too simplistic, the relationship between the travails of the Jesuits from the 1760 s into the 1810 s and the rise in the West of non-religious, or even anti-religious views of the world must still be addressed in any assessment of the suppression. This relationship is not straightforward. The data collection achieved by the old Society undoubtedly if unintentionally provided ammunition to those developing models of the universe that left no room for the supernatural or that at least assumed a deist position. And the varied post-1773 careers of ex-Jesuits suggest how diverse, secularized (or, depending on one's view, spiritually weakened), and individualistic the Jesuit experience had already become for some before the suppression had even arrived, and how the old Society was already engaged with and contributing to a secularized world it would later seem often to oppose. Jesuits both inadvertently added to and were carried along by the rejection of a theocentric worldview that characterized late eighteenth- and nineteenth-century European, and increasingly, North American thought. The restored Society's growth outside Europe is thus no accident.

The years of suppression and restoration, although they have received extensive attention during the past decade, continue to intrigue historians, and many questions remain unanswered. What, for instance, motivated young men to join the Society in the years immediately before its suppression, given the rapidly dimming prospects of the order? How might these motivations differ from those of men who had chosen similar paths a century earlier? What were the fates of the thousands of temporal coadjutors after 1773 ? How extensive and coordinated was the network of communication among former Jesuits? How was the next generation of Jesuits who led the Society after 1814 shaped by the experience of growing up without an institutional framework of Jesuit schools and mentors to shape them? How did former Jesuits fare in places such as Greece, where some stayed on but were isolated within the Ottoman realms? The experiences of Jesuits of non-European backgrounds, such as native-born Vietnamese and Chinese Jesuits, after 1773 likewise merits more study.

399 John W. O'Malley, "How the First Jesuits Became Involved in Education," in The Jesuit Ratio studiorum: 4ooth Anniversary Perspectives, ed. Vincent J. Duminico (New York: Fordham University Press, 2000), 56-79. 
The old Society for more than two centuries provided a clear avenue of advancement for young men whose interests were literary, artistic, or scientific yet compatible with a religious commitment - the restored Society, less obviously so. To cite one example of this shift, although missionary work continued to have some importance in the post-1814 Society, it seldom resulted in ethnographical works such as those by Éder or Baegert. Nor did the zoological reports of men like Eckart find many echoes after 1814. Likewise, Jesuit scholar-poets in the mold of Cordara and brothers who designed and decorated buildings are rare among the ranks of the nineteenth-century Jesuits. Jesuit astronomers persisted in a few locations, but their significance was a fraction of those of the old Society and waned further as the costs of producing state-of-the-art telescopes grew beyond the Society's means. Broader cultural forces drove some of these changes, but the modified goals, resources, and vision of the restored Society were also decisive, as were the personalities and talents of men who were now choosing to enter this new Society.

A reader of the literature dealing with the period of Jesuit history just covered will also be struck by the passionate hatred the Society inspired in some quarters. The history of Christianity has from its earliest days been marked by faction and bitter conflict, but the quality and quantity of the eighteenthcentury enemies of the Jesuits and the delight the Society's downfall produced are nonetheless striking. ${ }^{400}$ More than any other Catholic religious order, the Jesuits have been identified with a cluster of negative stereotypes that at times were as influential in shaping policy during the years of suppression as were any of the deeds of actual Jesuits. Strong emotions and vivid imaginations were moreover not the sole preserve of anti-Jesuits: more research needs to be done on the emotions the Jesuits themselves experienced and how these emotions shaped their perceptions and actions.

The exploration of these and other questions will further refine our picture of these key years, as well as help us to understand better the Society of Jesus as it exists today.

400 Sabina Pavone has identified four currents of anti-Jesuitism apparent before 1773. One of these currents, which Pavone calls "ecclesiastical anti-Jesuitism," was in her view fed by an unsympathetic reading of the voluminous Lettres édifiantes et curieuses, which detailed the Society's missionary activities. European Jesuits can hardly have been unaware of such an unsympathetic reading, and yet the Lettres continued to be published right up until—and after — the issuance of Dominus ac redemptor. Sabina Pavone, "The History of Anti-Jesuitism: National and Global Dimensions," in Banchoff and Casanova, Jesuits and Globalization, 111-30, here 119 . 


\section{Bibliography}

\section{Primary Sources}

Archivo Histórico Nacional, Inquisición, 3730, Exp. 149, 1770. http://pares.mcu.es/ ParesBusquedas/servlets/Control_servlet?accion=3\&\&txt_tipo_busqueda $=$ dl\&txt _busqueda=\&txt_correo=S\&txt_id_desc_ud=3741148 (accessed July 23, 2019).

The National Archives, Kew, Richmond, Surrey. http://discovery.nationalarchives.gov .uk/details/r/D338559 (accessed July 23, 2019).

\section{Secondary Sources}

Abreu, António Graça de. "Os bens dos últimos jesuítas portugueses em Pequim." Revista de cultura 37 (1988): 55-62.

Afinogenov, Gregory. "Jesuit Conspirators and Russia's East Asian Fur Trade, 1791-1807." Journal of Jesuit Studies 1, no. 2 (2015): 56-76.

Agarwal, Ravi P., and Syamal K. Sen. Creators of Mathematical and Computational Sciences. Cham: Springer, 2014.

Agnew, Hugh LeCaine. Origins of the Czech National Renascence. Pittsburgh: University of Pittsburgh Press, 1993.

Alden, Dauril. "Late Colonial Brazil, 1750-1808." In Colonial Brazil, edited by Leslie Bethell, 284-343. Cambridge: Cambridge University Press, 1987.

Alden, Dauril. The Making of an Enterprise: The Society of Jesus in Portugal, Its Empire, and Beyond. Stanford: Stanford University Press, 1996.

Altschul, Nadia R. Geographies of Philological Knowledge: Postcoloniality and the Transatlantic National Epic. Chicago: University of Chicago Press, 2012.

Analogías menos observadas de los tres reinos de la naturaleza. http://www.memori achilena.cl/602/w3-article-70971.html (accessed July 22, 2019).

Anichini, Pompeo. An Analytical and Historical View of the Catholic Religion. London: Bentley, 1826.

“Antiquariat Daša Pahor." https://www.pahor.de/maps-and-prints/asia/asia-asie.html (accessed July 22, 2019).

[Arouet, François-Marie]. Sermon du rabbin Akib, sur le dernier auto-da-fe de Lisbonne. Amsterdam: Veuve J. F. Jolly, 1762.

Assmann, Jan. Moses the Egyptian. Cambridge, MA: Harvard University Press, 1997.

Asúa, Miguel de. Science in the Vanished Arcadia: Knowledge of Nature in the Jesuit Missions of Paraguay and Río de la Plata. Leiden: Brill, 2014.

Baegert, Jacob. Nachrichten von der Amerikanischen Halbinsel Californien mit einem zweyfachen Anhand falscher Nachrichten. Mannheim: Churfürstl. Hof- und Academie-Buchdruckerey, 1773 . 
Bailey, Charles R. "French Secondary Education, 1763-1790: The Secularization of ExJesuit Collèges." Transactions of the American Philosophical Society 68, no. 6 (1978): $1-124$.

Bangert, William V. A History of the Society of Jesus. St. Louis, MO: Institute of Jesuit Sources, 1986.

Barnett, S. J. The Enlightenment and Religion: The Myths of Modernity. Oxford: Oxford University Press, 2003.

Bartusz-Dobosi, László. Jezsuiták és conquistadorok harca az indiánokért a XVII-XVIII. században. Budapest: Szent Gellért Kiadó, 2001.

Baur, Ferdinand. Church and Theology in the Nineteenth Century. Edited by Peter C. Hodgson, translated by Robert F. Brown and Peter C. Hodgson. Eugene, OR: Cascade Books, 2018.

Bayer, Wolfgang. Reise nach Peru. Edited by C. G. [Christoph Gottlieb] von Murr. Nuremberg: Bey Johann Eberhard Zeh, 1776.

Beales, Derek. Enlightenment and Reform in Eighteenth-Century Europe. London: I. B. Tauris, 2005 .

Beales, Derek. "The False Joseph II." Historical Journal 18 (1975): 467-95.

Beales, Derek. Prosperity and Plunder: European Catholic Monasteries in the Age of Revolution, 1650-1815. Cambridge: Cambridge University Press, 2003.

Beauvois, Daniel. "Les jésuites dans l'Empire russe (1772-1820)." Dix-huitième siècle 8 (1976): $257-72$.

Becker-Cantarino, Barbara. Aloys Blumauer and the Literature of the Austrian Enlightenment. Bern: Herbert Lang, 1973.

Bérenger, Jean. The Habsburg Empire, 1700-1918. Translated by C. A. Simpson. London: Longman, 1997.

Berger, Patricia. Empire of Emptiness: Buddhist Art and Political Authority in Qing China. Honolulu: University of Hawai'i Press, 2003.

Bernard, Howard Clive. The French Tradition in Education: Ramus to Mme. Necker de Saussure. Cambridge: Cambridge University Press, 1922.

Beschreibung der Landschaft Sonora samt andern merkwürdigen Nachrichten von den inneren Theilen Neu-Spaniens und Reise aus Amerika bis in Deutschland [...] von Ignaz Pfefferkorn. [Cologne]: Lang, 1794.

Biever, Albert Hubert. The Jesuits in New Orleans and the Mississippi Valley: Jubilee Memorial. New Orleans: n.p., 1924.

Binzley, Ronald A. "Ganganelli's Disaffected Children: The Ex-Jesuits and the Shaping of Early American Catholicism, 1773-179o." American Catholic Historian 26 (2008): 47-77.

Biographie universelle, ancienne et moderne. 85 Vols. Paris: Michaud, 1815.

Blin, Nicolas. Les martyrs de la révolution dans le diocèse de Séez. 3 Vols. Bar-le-Duc: Typographie des Célestines, 1876 . 
Blum, Jerome. The End of the Old Order in Rural Europe. Princeton: Princeton University Press, 1978.

Bolton, Charles A. Church Reform in 18th-Century Italy (the Synod of Pistoia 1786). The Hague: Martinus Nijhoff, 1969.

Boni, Onofrio. Elogio dell'abate Don Luigi Lanzi, tratto dalle sue opera. Pisa: Presso Niccolò Capurro, 1816.

Borao, José Eugenio. "Macao as the Non-entry Point to China: The Case of the Spanish Dominican Missionaries (1587-1632)." Paper presented at the International Conference "Role and Status of Macao in the Propagation of Catholicism in the East," Macao, November 3-5, 2009.

Borges, Charles J. The Economics of the Goa Jesuits, 1542-1759: An Explanation of Their Rise and Fall. New Delhi: Concept Publishing, 1994.

Borges, Charles J. "Racial Tensions of the Society of Jesus in India before 1759." In Jesuits in India: In Historical Perspective, edited by Teotónio R. de Souza and Charles Borges, 61-71. Macao: Instituto Cultural de Macau, 1992.

Borgo, Carlo. Analisi ed esame ragionato dell'arte della fortificazione e difesa delle Piazze. Venice: Antonio Zatta, 1777 .

Borja González, Galaxis. Die Jesuitische Berichterstattung über die Neue Welt. Göttingen: Vandenhoeck \& Ruprecht, 2011.

Bouchard, Norma, and Valerio Ferme. Italy and the Mediterranean: Words, Sounds, and Images of the Post-Cold War Era. Basingstoke: Palgrave Macmillan, 2013.

Bouffier, Gabriel. La vie du vénérable serviteur de Dieu, le père Joseph-Marie Pignatelli. Paris: Lecoffre, 1868.

Bowman, William David. Priest and Parish in Vienna: 1780 to 1880 . Boston: Humanities Press, 1999 .

Brading, D. [David] A. Church and State in Bourbon Mexico. Cambridge: Cambridge University Press, 1994.

Brnardić, Teodora Shek. "From Acceptance to Animosity: Trajectories of Croatian Jesuit Historiography.” https://bib.irb.hr/datoteka/935258.Shek_-_Croatian_Jesuit _Historiography.pdf (accessed July 22, 2019).

Bulle sollicitudo omnium ecclesiarum du o7 Août 1814 Pie VII. Lyon: M.-P. Rusand, 1814.

Il buon raziocinio dimostrato in due scritti, o siano saggi critico-apologetici sul famoso processo, e tragico fine del fu p. Gabriele Malagrida. Lugano, 1794.

Burnichon, Joseph. La Compagnie de Jésus en France 1814-1914. 4 Vols. Paris: Beauchesne, 1914-22.

Burrus, Ernest J. A Diary of Exiled Philippine Jesuits (1769-1770). Rome: Tip. Editrice Michele Pisani, 1951.

Burson, Jeffrey. "Distinctive Contours of Jesuit Enlightenment in France." In Exploring Jesuit Distinctiveness: Interdisciplinary Perspectives on Ways of Proceeding within the Society of Jesus, edited by Robert A. Maryks, 212-34. Leiden: Brill, 2016. 
Butterwick, Richard. "Catholicism and Enlightenment in Poland-Lithuania." In $A$ Companion to the Catholic Enlightenment in Europe, edited by Ulrich L. Lehner and Michael Printy, 297-358. Leiden: Brill, 2010.

Butterwick, Richard. The Polish Revolution and the Catholic Church, 1788-1792: A Political History. Oxford: Oxford University Press, 2012.

Byrnes, Joseph F. Priests of the French Revolution: Saints and Renegades in a New Political Era. University Park, PA: Pennsylvania State University Press, 2014.

Campbell, Thomas J. The Jesuits, 1534-1921: A History of the Society of Jesus from Its Foundation to the Present Time. New York: Encyclopedia Press, 1921.

Cannon, Thomas B. "History of the Jesuits in the Philippines: A Brief Sketch." Part 1. Woodstock Letters 66, no. 3 (1937): 364-86.

[Carafa, Giuseppe Maria]. Confutazione della Gazzetta ecclesiastica francese: Circa un' operetta stampata in Roma. Livorno, 1781.

Carte generale du cours du Gange et du Gagra, dressee sur les cartes particulieres $d u$ P. Tiefentaller, J. missionnaire apostolique dans l'Inde. Paris, 1784.

Caruana, Louis, S.J. "The Legacies of Suppression: Jesuit Culture and Science; What Was Lost? What Was Gained?" In The Jesuit Suppression in Global Context: Causes, Events, and Consequences, edited by Jeffrey D. Burson and Jonathan Wright, 262-77. Cambridge: Cambridge University Press, 2015.

Causa jesuitica de Portugal o documentos autenticos [...]. Madrid: En la imprenta Real de la Gazeta, 1768.

Chadwick, Owen. The Popes and European Revolution. Oxford: Clarendon Press, 1981.

Chan, Albert. Chinese Materials in the Jesuit Archives in Rome, 14th-2oth Centuries: A Descriptive Catalogue. Abingdon: Routledge, 2015.

Chapman, Charles E. “The Jesuits in Baja California (1697-1768)." Catholic Historical Review 6, no. 1 (1920): 46-58.

Chilidúgu, sive res Chilenses, vel descriptio status tum naturalis, tum civilis, cum moralis regni populique Chilensis, inserta suis locis perfectee ad Chilensem linguam manuductioni, [...] opera [...] Bernardi Havestadt [...]. Münster: Typis Aschendorfianis, 1777.

Chiu, Che-Bing. "Vegetal Travel:Western European Plants in the Garden of the Emperor of China." In Qing Encounters: Artistic Exchanges between China and the West, edited by Petra ten-Doesschate Chu and Ning Ding, 95-110. Los Angeles: Getty Research Institute Publications, 2015.

Clark, Jeremy. "From Kaifeng to Shanghai via Rome and Paris: Jesuits and the History of Judaism in China." In "The Tragic Couple”: Encounters between Jews and Jesuits, edited by James Bernauer and Robert A. Maryks, 125-44. Leiden: Brill, 2014.

Clark, William. "The Pursuit of the Prosopography of Science." In The Cambridge History of Science, vol. 4, Eighteenth-Century Science, edited by Roy Porter, 211-37. Cambridge: Cambridge University Press, 2003. 
Classen, Albrecht. Early History of the Southwest through the Eyes of German-Speaking Jesuit Missionaries. Lanham, MD: Lexington Books, 2013.

Clavijero, Francisco Javier. Historia de la Antigua o Baja California. Translated by Nicolás García de San Vicente. México: Porrúa, 1970.

Clay, Richard. "The Expulsion of the Jesuits and the Treatment of Catholic Representational Objects during the French Revolution." In The Jesuits II: Cultures, Sciences, and the Arts, 1540-1773, edited by John W. O'Malley, Gauvin Alexander Bailey, Steven J. Harris, and T. Frank Kennedy, 691-706. Toronto: University of Toronto Press, 2006.

Clossey, Luke. Salvation and Globalization in the Early Jesuit Missions. Cambridge: Cambridge University Press, 2008.

Coleti, Giovanni Antonio. Dizionario storico-geografico dell'America Meridionale. Venice: Stamperia Coleti, 1771.

Colombo, Emanuele. “Jesuit at Heart: Luigi Mozzi de' Capitani (1746-1813) between Suppression and Restoration." In Jesuit Survival and Restoration: A Global History, 1773-190o, edited by Robert A. Maryks and Jonathan Wright, 212-28. Leiden: Brill, 2014.

Compendio storico di memorie cronologiche concernenti la religione e la morale della nazione armena suddita dell'Impero ottomano, opera divisa in sei libri [...] dal marchese Giovanni de Serpos. Venice: Stamp. di C. Palese, 1786.

Conrads, Norbert, ed. Die tolerierte Universität: зоo Jahre Universität Breslau 1702 bis 2002. Wiesbaden: Franz Steiner, 2002.

Cordara, Giulio Cesare. Capitoli sulla parrucca del P. Ruggiero Boschovik [sic] e due egloghe militari. Osimo: Domenicantonio Quercetti, 1792.

Čornejová, Ivana. "Správní a institucionální vývoj pražské univerzity (Vztah univerzity k panovníkovi, správním a zemským orgánům)." In Karel Beránek et al., Dějiny Univerzity Karlovy II, 1622-1802, 23-56. Prague: Univerzita Karlova, 1996.

Čornejová, Ivana, and Anna Fechtnerová. Životopisný Slovník Pražské Univerzity: Filozofická a teologická fakulta 1654-1773. Prague: Univerzita Karlova, 1986.

Cowgill, Rachel. "New Light and the Man of Might: Revisiting Early Interpretations of Die Zauberflöte." In Art and Ideology in European Opera: Essays in Honour of Julian Rushton, edited by Rachel Cowgill, David Cooper, and Clive Brown, 194-201. Woodbridge: Boydell Press, 2010.

Crétineau-Joly, Jacques-Augustin-Marie. Histoire religieuse, politique et littéraire de la Compagnie de Jésus. 3rd ed. 6 Vols. Paris: Lecoffre, 1859.

Cubitt, Geoffrey. The Jesuit Myth: Conspiracy Theory and Politics in Nineteenth-Century France. Oxford: Clarendon Press, 1993.

Cullum, Leo A. "Review of Philippine Jesuits in Exile, by Nicholas P. Cushner." Philippine Studies 13, no. 2 (1965): 391-93. 
Curran, Robert Emmett. A History of Georgetown University. 3 Vols. Washington, DC: Georgetown University Press, 2010.

Cushner, Nicholas P. Jesuit Ranches and the Agrarian Development of Colonial Argentina, 1650-1767. Albany: State University of New York Press, 1983.

D'Addio, Mario. The Galileo Case: Trial, Science, Truth. Translated by Brian Williams. Leominster and Rome: Gracewing and Nova Millennium, 2004.

Daniel-Rops, Henri. History of the Church of Christ, vol. 8, The Church in the Age of Revolution. Translated by John Warrington. New York: Dutton, 1965 .

Danova, Penka. “Franjo Ksaver Pejačević a-t-il écrit une histoire des bulgares?" Études balkaniques 54, no. 2 (2018): 205-30.

De la Brosse, Jean-Baptiste. À la recherche d'un signe perdu:Jean-Baptiste de la Brosse, S.J., Éléments de langue montagnaise (1768). Edited by Jean-François Cottier and Renée Lambert-Brétière. Neuville sur Saône: Chartae Neolatinae, 2018.

De la Fontaine, François Leopold. Chirurgisch-medicinische Abhandlungen verschiedenen Inhalts Polen betreffend. Breslau and Leipzig: Wilhelm Gottlieb Korn, 1792.

De Lucca, Dennis. Jesuits and Fortifications: The Contribution of the Jesuits to Military Architecture in the Baroque Age. Leiden: Brill, 2012.

Del Rey Fajardo, José. Los jesuitas en Venezuela: Las misiones germen de la nacionalidad. Caracas and Bogotá: Universidad Católica Andrés Bello, 2007.

Delahaye, Hippolyte. The Work of the Bollandists through Three Centuries, 1615-1915. Princeton: Princeton University Press, 1922.

Denoth, Armin. "Professor Matheseos Dr. phil. Ignaz von Weinhart, S.J. ${ }^{1705-1787}$ zum 300. Geburtstag des Gründers der Experimentalphysik an der Universität in Innsbruck." Berichte des Naturwissenschaftlich-medizinischer Vereins in Innsbruck 92 (2005): 351-61.

Dimitz, August. History of Carniola: From Ancient Times to the Year 1813. Translated by Andrew J. Witter. 4 Vols. [Bonita Springs, FL]: Slovenian Genealogy Society International, 2013.

Dobrowsky, Josef. "Streitschriften über die Existenz des heil. Johann von Nepomuk." Literarisches Magazin für Böhmen und Mähren 3 (1787): 101-26.

"Dominus ac redemptor noster Bull of Pope Clement XIV Permanently Suppressing the Jesuit Order." http://www.reformation.org/jesuit-suppression-bull.html (accessed July 24, 2019).

Dooley, Brendan. "The Storia letteraria d'Italia and the Rehabilitation of Jesuit Science." In Jesuit Science and the Republic of Letters, edited by Mordechai Feingold, 433-73. Cambridge, MA: MIт Press, 2003.

Drolet, Antonio. "La bibliothèque du Collège des Jésuites." Revue d'histoire de l'Amérique française 14 , no. 4 (1961): 487-544. 
Duller, Eduard. Die Jesuiten wie sie waren und wie sie sind. Berlin: Carl Klemann, 1845. Duteil, Jean-Pierre. Le mandat du ciel: Le rôle des jésuites en Chine. Paris: Editions arguments, 1994 .

Dutton, George. A Vietnamese Moses: Philiphê Binh and the Geographies of Early Modern Catholicism. Berkeley: University of California Press, 2017.

Echeverria, Javier, Andoni Ibarra, and Thomas Mormann. "The Long and Winding Road to the Philosophy of Science in Spain." In Representations of Scientific Rationality: Contemporary Formal Philosophy of Science in Spain, edited by Andoni Ibarra and Thomas Mormann, 11-56. Amsterdam: Rodopi, 1997.

Eckhel, Joseph Hilarius. Kurzgefaßte Anfangsgründe zur alten Numismatik. Vienna: Kurzbeck, [1786?].

Eder, Franciscus Javier. Descriptio provinciae Moxitarum in Regno Peruano. Edited by Pál Makó de Kerek. Buda: Typis Universitatis, 1791.

Edmundson, George. "Spain and Portugal (1746-1794)." In The Cambridge Modern History, vol. 6, The Eighteenth Century, edited by A. W. [Adolphus William] Ward, George W. Prothero, and Stanley Leathes, 361-88. Cambridge: Cambridge University Press, 1909.

Egido, Teófanes. "El siglo XVIII: Del poder a la extinción." In Los jesuitas en España y en el mundo hispánico, edited by Teófanes Egido López, Teófanes Egido, Javier Burrieza Sánchez, and Manuel Revuelta González, 225-78. Madrid: Fundación Carolina Centro de Estudios hispánicos e iberoamericanos and Marcial Pons, 2004.

Egiguren Iraola, Antton. True Confucians, Bold Christians: Korean Missionary Experience, a Model for the Third Millennium. Amsterdam; Rodopi, 2007.

Elementa calculi differentialis et integralis conscripta a Stanislao Wydra. Prague and Vienna: Apud Ioan. Ferd. Nob. a Schönfeld, 1783.

Elman, Benjamin A. “The Jesuit Role as 'Experts' in High Qing Cartography and Technology." Taida lishi xuebao 31 (2003): 223-50.

Ennes, Ernesto. "Teresa Margarida da Silva e Orta, a Brazilian Collaborator in the AntiJesuit Propaganda of Pombal." Americas 2, no. 4 (1946): 423-30.

Epstein, Klaus. The Genesis of German Conservatism. Princeton: Princeton University Press, 1966.

Escoto, Salvador P. "Governor Anda and the Liquidation of the Jesuit Temporalities in the Philippines, 1770-1776." Philippine Studies 23, no. 3 (1975): 293-319.

Espíndola, Walter Hanisch. Itinerario y pensamiento de los jesuitas expulsos de Chile. Santiago de Chile: Andrés Bello, 1972.

Falkner, Thomas. A Description of Patagonia, and the Adjoining Parts of South America. Edited by William Combe. Hereford: C. Pugh, 1774. 
Fernández Arrillaga, Inmaculada. El destierro de los jesuitas castellanos (1767-1815). [Valladolid]: Junta de Castilla y Léon, 2004.

Fernández Arrillaga, Inmaculada, and Niccolò Guasti. "The Exiled Spanish Jesuits and the Restoration of the Society of Jesus." In Jesuit Survival and Restoration: A Global History, 1773-19oo, edited by Robert A. Maryks and Jonathan Wright, 178-96. Leiden: Brill, 2014.

Ferrer Benimeli, José A. José Pignatelli, S.J. (1737-1811): La cara humana de un santo. Bilbao: Mensajero D.L., 2011.

Florovskij, Anton V. Ceští Jesuité na Rusi: Jesuité ceské provincie a slovensky vychod. Prague: Vyšehrad, 1941.

Florovskij, Anton V. "Pervy Iezuit iz moskovskikh dvoryan." Acta Academiae Velehradensis 19 (1948): 249-56.

Florovsky, Georges. Ways of Russian Theology. Translated by Robert L. Nichols. Belmont, MA: Nordland, 1979.

Flynn, James T. "The Role of the Jesuits in the Politics of Russian Education, 1801-1820." Catholic Historical Review 56, no. 2 (1970): 249-65.

Flynn, Thomas O. The Western Christian Presence in the Russias and Qājār Persia, c.176o-c.1870. Leiden: Brill, 2017.

Foley, Henry. Records of the English Province of the Society of Jesus. 7 Vols. London: Burns \& Oates, $1877-83$.

Fontana Castelli, Eva. "Profezie apocalittiche e identità gesuitica: Niccolò Paccanari e i padri della fede nella Roma di fine Settecento." Dimensioni e problemi della ricerca storica: Rivista del Dipartimento di Storia Moderna e Contemporanea dell'Università degli Studi di Roma "La Sapienza" 1 (2003): 111-30.

Fontana Castelli, Eva. "The Society of Jesus under another Name: The Paccanarists in the Restored Society of Jesus." In Jesuit Survival and Restoration: A Global History, 1773-1900, edited by Robert A. Maryks and Jonathan Wright, 197-211. Leiden: Brill, 2014.

Fortsetzung und Ergänzungen zu Christian Gottlieb Jöchers allgemeinem GelehrtenLexico [sic] [...] Dritter Band. Delmenhorst: Georg Jöntz, 1810.

Frazee, Charles A. Catholics and Sultans: The Church and the Ottoman Empire 1453-1923. Cambridge: Cambridge University Press, 1983.

Frykenberg, Robert Eric. Christianity in India: From Beginnings to the Present. Oxford: Oxford University Press, 2008.

Gagarin, J. [Jean]. Les jésuites de Russie. Paris: Victor Palmé, 1872.

Gagarin, J. [Jean]. "Review of Lettres et documents inédits, by Auguste Carayon." Études religieuses historiques et littéraires 4, no. 4 (1869): 459-69.

Galasi, Francis B. "Jesuits in the Philippines: Politics and Missionary Work in the Colonial Setting." MA thesis, CUNY City College of New York, 2014. https://aca demicworks.cuny.edu/cc_etds_theses/539/ (accessed July 24, 2019). 
Ganson, Barbara Anne. The Guaraní under Spanish Rule in the Río de la Plata. Stanford: Stanford University Press, 2003.

Gao, Jie. "The Influence of Chinese Musical Instruments on the Violin: A Practice Guide of Three Musical Techniques." DMA diss., University of North Texas, 2017. https://digital.library.unt.edu/ark:/67531/metadc1011757/m2/1/high_res_d/GAO -DISSERTATION-2017.pdf (accessed July 26, 2019).

Garfinkle, Robert A. "Triesnecker, Franz (Francis) de Paula." In Biographical Encyclopedia of Astronomers, edited by Thomas Hockey, Virginia Trimble, Thomas R. Williams, Katherine Bracher, Richard A. Jarrell, Jordan D. Marchéll, JoAnn Palmieri, and Daniel W. E. Green, 1:1149. 2 Vols. New York: Springer Reference, 2014.

Gerbi, Antonello. The Dispute of the New World: The History of a Polemic, 1750-190o. Translated by Jeremy Moyle. Pittsburgh: University of Pittsburgh Press, 1973.

[Gioberti, Vincenzo]. Vita di Fra Lorenzo Ganganelli, Papa Clemente XIV: Nuova edizione. n.p., 1847.

Glüsenkamp, Uwe. Das Schicksal der Jesuiten aus der Oberdeutschen und den beiden rheinischen Ordensprovinzen nach ihrer Vertreibung aus den Missionsgebieten des portugiesischen und spanischen Patronats (1755-1809). Münster: Aschendorff, 2008.

Göttingische Anzeigen von gelehrten Sachen. Göttingen: Johann Christian Dieterich, 1778.

Goss, Robert E. "The First Meeting of Catholic Scholasticism with dGe lugs pa Scholasticism." In Scholasticism: Cross-Cultural and Comparative Perspectives, edited by José Ignacio Cabezón, 65-90. Albany: State University of New York Press, 1998.

Gramoza, José Pedro Ferrás. Successos de Portugal: Memorias historicas, politicas e civis. Lisbon: Typographia do Diário da Manhã, 1882.

Grendler, Paul F. The Jesuits and Italian Universities, 1548-1773. Washington, DC: Catholic University of America Press, 2017.

Grover, Mark L. "The Book and the Conquest: Jesuit Libraries in Colonial Brazil." Libraries \& Culture 28, no. 3 (1993): 266-83.

Guasti, Niccolò. "Catholic Civilization and the Evil Savage: Juan Nuix Facing the Spanish Conquista of the New World." In Encountering Otherness: Diversities and Transcultural Experiences in Early Modern Europe, edited by Guido Abbatista, 285-302. Trieste: Università di Trieste, 2011.

Guasti, Niccolò. "The Exile of Spanish Jesuits in Italy (1767-1815)." In The Jesuit Suppression in Global Context: Causes, Events, and Consequences, edited by Jeffrey D. Burson and Jonathan Wright, 248-61. Cambridge: Cambridge University Press, 2015.

Gunn, Geoffrey C. First Globalization: The Eurasian Exchange, 1500 to 1800 . Lanham, MD: Rowman \& Littlefield, 2003. 
Gusti, Francesco. Historya kościoła ruskiego. Translated by Jan Ławrowski. 2 Vols. Kraków: Nakł. i czcionkami Karola Budweisera, 1857-58.

H. L. R. "The Suppression of the Jesuits by Pope Clement XIV." American Catholic Quarterly Review 13, no. $5^{2}$ (1888): 696-706.

Haberzettl, Hermann. Die Stellung der Exjesuiten in Politik und Kulturleben Österreichs zuEnde des 18.Jahrhunderts. Vienna:Verband derWissenschaftlichen Gesellschaften Österreichs, 1973 .

Halliwell, Ruth. The Mozart Family: Four Lives in a Social Context. Oxford: Clarendon Press, 1998.

Hartley, Janet M. Russia, 1762-1825: Military Power, the State, and the People. Westport: Praeger, 2008.

Haskell, Yasmin. Loyola's Bees: Ideology and Industry in Jesuit Latin Didactic Poetry. Oxford: Oxford University Press, 2003.

Haskell, Yasmin. "Suppressed Emotions: The Heroic Tristia of Portuguese (Ex-)Jesuit, Emanuel de Azevedo." Journal of Jesuit Studies 3, no. 1 (2016): 42-6o.

Hawkes-Teeples, Steven. "Russia." In The Cambridge Encyclopedia of the Jesuits, edited by Thomas Worcester, 702-4. Cambridge: Cambridge University Press, 2017.

Hazard, Paul. European Thought in the Eighteenth Century. Translated by J. [James] Lewis May. London: Hollis and May, 1954.

Healy, Roísin. The Jesuit Specter in Imperial Germany. Boston: Brill, 2003.

Hechenberger, Daniel. "The Jesuits: History and Impact; From Their Origins prior to the Baroque Crisis to Their Role in the Illinois Country." Journal of the Illinois State Historical Society 100, no. 2 (2007): 85-109.

Heilbron, John L. "Boscovich in Britain." In Relocating the History of Science: Essays in Honor of Kostas Gavroglu, edited by Theodore Arabatzis, Jürgen Renn, and Ana Simões, 99-116. Cham: Springer, 2015.

Heimbucher, Max. Die Orden und Kongregationen der katholischen Kirche. Paderborn: Schöningh, 1908.

Henry, Gilles. "Letter from Mozdok, March 18, 1812." Translated by C. [Conrad] M. Widman. Woodstock Letters 1, no. 1 (1900): 56-6o.

Herr, Richard. The Eighteenth-Century Revolution in Spain. Princeton: Princeton University Press, 1958.

[Holland, Henry Richard Vassall, Baron (?)]. An Account of the Suppression of the Jesuits in Spain: Extracted from a Letter of Lord Holland. [London]: [S. \& R. Bentley], [between 1800 and 1899].

Holt, Geoffrey. "The English Ex-Jesuits and Jesuits and the Missions 1773-1814." In Promising Hope: The Suppression and Restoration of the English Province of the Society of Jesus, edited by Thomas McCoog, 177-90. Rome: Institutum Historicum Societatis Iesu, 2003. 
Holt, Geoffrey. "The English Province: The Ex-Jesuits and the Restoration." In Promising Hope: The Suppression and Restoration of the English Province of the Society ofJesus, edited by Thomas McCoog, 219-58. Rome: Institutum Historicum Societatis Iesu, 2003. Holt, Geoffrey. "The Letters from Rome of John Thorpe, S.J., to Charles Plowden, S.J., 1784-92." Recusant History 28, no. 3 (2007): 434-57.

Horvath, Joannes Baptista. Declaratio infirmitatis fundamentorum operis Kantiani Critik der reinen Vernunft. Buda: Typ. Regiæ Universitatis Pestiensis, 1797.

Hoxby, Blair. "The Baroque Tragedy of the Roman Jesuits: Flavia and Beyond." In Politics and Aesthetics in European Baroque and Classicist Tragedy, edited by Jan Bloemendal and Nigel Smith, 182-218. Leiden: Brill, 2016.

Hsia, Ronnie Po-chia. The World of Catholic Renewal 1540-1770. 2nd ed. Cambridge: Cambridge University Press, 2005.

Hughes, Thomas. History of the Society of Jesus in North America Colonial and Federal Documents: Volume I, Part II; Nos. 141-224 (1605-1838). London: Longmans, Green \& Co., 1910.

Imposturce CCXVIII. in dissertatione B. Cetto [...] de Sinensium imposturis detectce et convulsæ: Accedunt epistole anecdotce R. P. Augustini e comitibus Hallerstein ex China scriptae. Buda: Typis Regiae Universitatis, 1781.

Inglot, Marek. La Compagnia di Gesù nell'Impero Russo (1772-1820) e la sua parte nella restaurazione generale della Compagnia. Rome: Editrice Pontificia Università Gregoriana, 1997.

Inglot, Marek. "Le missioni della Compagnia di Gesù di Russia Bianca." Studia missionalia 60 (2011): 319-54.

Inglot, Marek. "The Society of Jesus in the Russian Empire (1772-1820) and the Restoration of the Order." In Jesuit Survival and Restoration: A Global History, 1773190o, edited by Robert A. Maryks and Jonathan Wright, 67-82. Leiden: Brill, 2014.

Instructio privata seu typus cursus annui pro sex humanioribus classibus in usum magistrorum Societatis Jesu editus. Prague: Typis Universitatis Carlo-Ferd., 1735.

Israel, Jonathan. Democratic Enlightenment: Philosophy, Revolution, and Human Rights 1750-179o. Oxford: Oxford University Press, 2011.

James, William A. "The Jesuits' Role in Founding Schools in Late Tsarist Russia." In Religious and Secular Forces in Late Tsarist Russia: Essays in Honor of Donald W. Treadgold, edited by Charles E. Timberlake, 48-64. Seattle: University of Washington Press, 1992.

"Jesuit Restoration 1814." http://www.sj2014.net/blog/category/italy (accessed July 25, 2019).

Južnič, Stanislav. "Central European Jesuit Scientists in China and Their Impact on Chinese Science." Asian Studies 2, no. 3 (2015): 89-118. DoI: 10.4312/as.2015·3.2.89-118 (accessed July 26, 2019). 
Južnič, Stanislav. "Euler and the Jesuits in Russia." Quaderns d'història de l'enginyeria 9 (2008): 219-47.

Južnič, Stanislav. “Theodor Kravina Cronstain i njegove veze s isusovačkim kolegijem u Varaždinu (obljetnica četvrtine tisućljeća imenovanja varaždinskog profesora Cronstaina rektorom Theresianuma u Beču)." Radovi Zavoda za znanstveni rad HAZU Varaždin 28 (2017): 353-66.

Kadulska, Irena. "The Połock Academy (1812-1820): An Example of the Society of Jesus's Endurance." In The Jesuit Suppression in Global Context: Causes, Events, and Consequences, edited by Jeffrey D. Burson and Jonathan Wright, 83-98. Cambridge: Cambridge University Press, 2015.

[Katona, István]. Orationes Stephani Katona [...] quas triduo exercitiorum spiritualium in hebdomada maiore. Pest: Matthiae Trattner, 1813.

Kennedy, J. H. [John Hopkins]. Jesuit and Savage in New France. New Haven: Yale University Press, $195^{\circ}$.

Kerson, Arnold J. “Diego José Abad, Dissertatio Ludicro-seria." Humanistica Lovaniensia 40 (1991): 357-74.

Kilroy, Phil. Madeleine Sophie Barat, 1779-1865: A Life. New York: Paulist Press, 2000.

Kladky, William P. "Jesuits." In Encyclopedia of the Atlantic World, 140o-19oo: Europe, Africa, and the Americas in an Age of Exploration, Trade, and Empires, edited by David Head, 337-40. Santa Barbara: ABC-CLIO, 2018.

Kochhar, R. [Rajesh] K. "Secondary Tools of Empire." In Discoveries, Missionary Expansion, and Asian Cultures, edited by Teotónio R. de Souza, 175-83. New Delhi: Concept Publishing, 1994.

Krahl, Joseph. China Missions in Crisis: Bishop Laimbeckhoven and His Times, 1738-1787. Rome: Gregorian University Press, 1964.

Krükl, Karl. Leben und Werke des elsässischen Schriftstellers Anton von Klein. Paderborn: Salzwasser Verlag, 2015.

Kuzniewski, Anthony J. "Francis Dzierozynski and the Jesuit Restoration in the United States." Catholic Historical Review 78, no. 1 (1992): 51-73.

Laamann, Lars Peter. Christian Heretics in Late Imperial China. Abingdon: Routledge, 2006.

Lambert, John. Travels through Canada and the United States of North America in the Years 1806, 1807, and 1808. 2 Vols. London: Cradock and Joy, 1813.

"Language-Learning in the 18th-Century Russian Empire." http://quellen-perspectivia .net/en/langlearninginruss/Angiolini (accessed July 26, 2019).

Lanska, Douglas J., and Joseph T. Lanska. "Franz Anton Mesmer and the Rise and Fall of Animal Magnetism: Dramatic Cures, Controversy, and Ultimately a Triumph for the Scientific Method." In Brain, Mind, and Medicine: Essays in Eighteenth-Century Neuroscience, edited by Harry Whitaker, C. U. M. [Christopher Upham Murray] Smith, and Stanley Finger, 307-20. New York: Springer, 2007. 
Lapomarda, Vincent A. The Jesuit Heritage in New England. Worcester, MA: Jesuits of Holy Cross College, 1977.

Lazouski, Yahor, Aliaksandr Paprauka, Dzmistry Lazouski, and Aliaksandr Bakatovich. "Characterisation and Rehabilitation of One of the Historical Buildings of the Polotsk Campus of the Polotsk State University." In Nondestructive Techniques for the Assessment and Preservation of Historic Structures, edited by Luisa Maria da Silva Gonçalves, Hugo Rodrigues, and Florindo Gaspar, 140-50. Boca Raton: CRC Press, 2018.

Lec, Zdzislaw. Jezuici we Wroctawiu (1581-1776). Wrocław: PWT, 1995.

Lécrivain, Philippe. "Une prosopographie des ex-jésuites 'parisiens' (1762-1848)." Mélanges de l'École française de Rome: Italie et Méditerranée modernes et contemporaines 126, no. 1 (2014). https://journals.openedition.org/mefrim/1670\#toctoin2 (accessed July 26, 2019).

Lehmann, Max. Preussen und die katholische Kirche seit 1640: Fünfter Teil; Von 1775 bis 1786. Leipzig: Hirzel, 1885 .

Lehner, Ulrich L. Enlightened Monks: The German Benedictines 1740-1803. Oxford: Oxford University Press, 2011.

Lehner, Ulrich L. "Introduction: The Many Faces of Catholic Enlightenment." In $A$ Companion to the Catholic Enlightenment in Europe, edited by Ulrich L. Lehner and Michael Printy, 1-61. Leiden: Brill, 2010.

Leite, Serafim. Artes e ofícios dos jesuitas no Brasil (1549-1760). Lisbon: Edições Brotéria, 1953.

Lettre aux Espagnols américains: Par un de leurs compatriotes. Philadelphie [London], 1799.

Liber saecularis historiae Societatis Jesu ab anno 1814 usque ad annum 1914. Rome: Typis Polyglottis Vaticanis, 1914.

Libois, Charles, ed. Monumenta Proximi Orientis, VI Égypte (1700-1773). Rome: Institutum Historicum Societatis Iesu, 2003.

"The Library of Jesuit College in University Library Rijeka." https://svkri.uniri.hr/digi talno/files/original/Izlo_ba_plakata_na_Korzu/Plakati.pdf (accessed July 26, 2019).

Lichocka, Halina. "Miesięcznik połocki' (1818-1820): Kontekst historyczny i bibliografia zawartości." In Wkład jezuitów do nauki i kultury w Rzeczypospolitej Obojga Narodów i pod zaborami, edited by Irena Stasiewicz-Jasiukowa, 631-62. Kraków: Wydaw. WAM, 2004.

Lipowsky, Felix Joseph. Geschichte der Jesuiten in Tirol. Munich: Jakob Giel, 1822.

Ljubičić, Ivan. "Podrijetlo Hrvata Tragom Hrvatskoga Imena." PhD diss., University of Zagreb, 2012. http://darhiv.ffzg.unizg.hr/id/eprint/2420/2/DIPLOMSKI-Ljubicic _Ivan.pdf (accessed July 26, 2019).

Lucci, Diego. "The Suppression of the Jesuits and the Enlightenment Discourse of Jewish Emancipation: Two Parallel Historical Phenomena." In "The Tragic Couple": 
Encounters between Jews and Jesuits, edited by James Bernauer and Robert A. Maryks, 87-102. Leiden: Brill, 2014.

Lüsebrink, Hans-Jürgen. "Between Ethnology and Romantic Discourse: Martin Dobrizhoffer's History of the Apibones in a (Post)modern Perspective." In Jesuit Accounts of the Colonial Americas: Intercultural Transfers, Intellectual Disputes, and Textualities, edited by Marc André Bernier, Clorinda Donato, and Hans-Jürgen Lüsebrink, 127-43. Toronto: University of Toronto Press, 2014.

Maas, Robin, and Gabriel O'Donnell. Spiritual Traditions for the Contemporary Church. Nashville: Abingdon, 1990.

MacGill, Thomas. A Hand Book, or Guide, for Strangers Visiting Malta. Malta: Luigi Tonna, 1839 .

Mädler, Johann Heinrich. Geschichte der Himmelskunde. 2 Vols. Braunschweig: George Westermann, 1873 .

Madzsar, Imre. “A budai jezsuita akadémia története." Magyar pedagógia: A Magyar Tudományos Akadémia Pedagógiai Bizottságának folyóirata 35 (1926):1-12.

Malagrida, Gabriele. Juizo da verdadeira causa do terremoto, que padeceo a corte de Lisboa, no primeiro de novembro de 1755. Lisbon: Na Regia Officina Typografica, 1774. Manchaca, Roque, ed. Epistolae Sancti Ignatii Loyolae. Bologna: Typis Gasparis de Franciscis, 1804.

Manchado, Marta María. Consecuencias de la expulsión de los jesuitas: Filipinas. Madrid: Fundación Ignacio Larramendi, $c .2005$.

Maréchal, Pierre-Sylvain [?]. Almanach des honnêtes gens, contenant les prophéties pour chaque mois de l'année 1793 [...]. Paris, 1793.

Marin, Catherine. "La mission française de Pékin après la suppression de la Compagnie de Jésus en 1773." Transversalités 107 (2007). DOI:10.3917/trans.107.0009 (accessed July 26, 2019).

Martin, James. "Pope Francis' Address to the Jesuits on the Anniversary of Their Restoration." America (September 27, 2014). https://www.americamagazine.org/ faith/2014/09/27/pope-francis-address-jesuits-anniversary-their-restoration (accessed July 26, 2019).

Martonfi, Antonius. Initia astronomica speculae Batthyanianae Albensis in Transilvania. Alba Iulia: Typis Episcopalibus, 1798.

Mascarenhas, Mira. "The Church in Eighteenth-Century Goa." In Essays in Goan History, edited by Teotónio R. de Souza, 81-101. New Delhi: Concept Publishing, 1989.

Mateos, Fernando, S.J. Suppression and Restoration of the Society of Jesus in China. http://www.riccimac.org/doc/monographs/1/suppression_and_restoration_of_the _society_of_jesus_in_china.pdf (accessed July 29, 2019).

Maxwell, Kenneth. "The Spark: Pombal, the Amazon, and the Jesuits." Portuguese Studies 17 (2001): 168-83. 
McCoog, Thomas M. "Est et non est': Jesuit Corporate Survival in England after the Suppression." In Jesuit Survival and Restoration: A Global History, 1773-19oo, edited by Robert A. Maryks and Jonathan Wright, 162-77. Leiden: Brill, 2014.

McCoog, Thomas M. "Libera nos Domine?' The Vicars Apostolic and the Suppressed/ Restored English Province of the Society of Jesus." In Early Modern English Catholicism: Identity, Memory, and Counter-Reformation, edited by James E. Kelly and Susan Royal, 81-101. Leiden: Brill, 2017.

McCoog, Thomas M., ed. Promising Hope: The Suppression and Restoration of the English Province of the Society of Jesus. Rome: Institutum Historicum Societatis Iesu, 2003.

McGreevy, John T. "Restored Jesuits: Notes toward a Global History." In The Jesuits and Globalization: Historical Legacies and Contemporary Challenges, edited by Thomas Banchoff and José Casanova, 131-46. Washington, DC: Georgetown University Press, 2016.

McGucken, William J. The Jesuits and Education: The Society's Teaching Principles and Practice, Especially in Secondary Education in the United States. Eugene, OR: Wipf and Stock, 2008.

McIntosh, Christopher. The Rose Cross and the Age of Reason: Eighteenth-Century Rosicrucianism in Central Europe and Its Relation to the Enlightenment. Leiden: Brill, 2011.

Meehan, John, and Jacques Monet. "The Restoration in Canada: An Enduring Patrimony." In Jesuit Survival and Restoration: A Global History, 1773-19oo, edited by Robert A. Maryks and Jonathan Wright, 386-98. Leiden: Brill, 2014.

Melvin, Karen. Building Colonial Cities of God: Mendicant Orders and Urban Culture in New Spain. Stanford: Stanford University Press, 2012.

Menyhárt, Ágnes. "Magyar jezsuiták Brazíliában, 1753-176o." Világtörténet 38, no. 2 (2016): 219-322.

Merino, Olga, and Linda A. Newson. "Jesuit Missions in Spanish America: The Aftermath of the Expulsion." Revista de historia de América 118 (1994): 7-32.

Merrick, Jeffrey. "Claude Amable de Cohade de La Garderie: Family Conflict and Political Conspiracy under Louis XV." Journal of Canadian History 52, no. 1 (2017): 1-28.

Midelfort, H. C. [Hans Christian] Erik. Exorcism and Enlightenment: Johann Joseph Gassner and the Demons of Eighteenth-Century Germany. New Haven: Yale University Press, 2005.

Mijailović, Jasna. "The Origin and Role of the Emblem in the Serbian Orthodox Church of the 18th Century on the Territory of the Habsburg Monarchy." Lecture, Tenth International Conference Society for Emblem Studies, Christian-AlbrechtsUniversität zu Kiel, July 28, 2014. http://arkyves.org/static/misc/kiel_mijailovic.pdf (accessed July 29, 2019). 
Miller, James Rodger. Equal Rights: The Jesuits Estates Act Controversy. Montreal: McGill-Queen's University Press, 1979.

Miller, Samuel J. Portugal and Rome c.1748-1830: An Aspect of the Catholic Enlightenment. Rome: Università Gregoriana Editrice, 1978.

Mörner, Magnus. "The Expulsion of the Jesuits from Spain and Spanish America in 1767 in Light of Eighteenth-Century Regalism." Americas 23, no. 2 (1966): 156-64.

Morris, John. Catholic England in Modern Times. London: Burns \& Oates, 1892.

Morrissey, Thomas J. Peter Kenney, S.J., 1779-1841: The Restoration of the Jesuits in Ireland, England, Sicily, and North America. Washington, DC: Catholic University of America Press, 2014.

Murphy, Thomas. Jesuit Slaveholding in Maryland, 1717-1838. New York: Routledge, 2001. Musillo, Marco. The Shining Inheritance: Italian Painters at the Qing Court, 1699-1812. Los Angeles: Getty Research Institute, 2016.

Neill, Stephen. A History of Christianity in India: 1707-1858. Cambridge: Cambridge University Press, 1985.

Nelson, Eric. The Jesuits and the Monarchy: Catholic Reform and Political Authority in France (1590-1615). [London?]: Routledge, 2017.

Newitt, Malyn. A History of Mozambique. Bloomington, IN: Indiana University Press, 1995 .

Nianzu, Dai. "The Development of Modern Physics in China: The 5oth Anniversary of the Chinese Physical Society." In Chinese Studies in the History and Philosophy of Science and Technology, edited by Fan Dainian and Robert S. Cohen, 207-18. Dordrecht: Kluwer, 1996.

Nicodemos of Holy Mountain. Nicodemos of the Holy Mountain: A Handbook of Spiritual Counsel. Translated by Peter A. Chamberas. New York: Paulist Press, 1989.

Nicolai, Friedrich. Beschreibung einer Reise durch Deutschland und die Schweiz im Jahre 1781. 12 Vols. Berlin and Stettin: [Selbstverl.], 1781-96.

Nii, Yoko. "The Jesuit Jean-Joseph-Marie Amiot and Chinese Music in the Eighteenth Century." In Europe and China: Science and Arts in the 17th and 18th Centuries, edited by Luis Saravia, 81-92. Hackensack: World Scientific, 2012.

A Note, in Addition to That of 1845: On the Jesuits' Estates [...]. Quebec: Fréchette et Frères, 1847 .

Obituaries. Wigan: Catholic Record Society, 1913.

O'Brien, G. "The Survival of the Jesuits in White Russia." Irish Monthly 42, no. 497 (1914): $597-607$.

Okenfuss, Max Joseph. The Rise and Fall of Latin Humanism in Early Modern Russia: Pagan Authors, Ukrainians, and the Resiliency of Moscow. Leiden: Brill, 1995.

O'Leary, Brian. "Jesuit Spirituality before and after the Suppression." Studies: An Irish Quarterly Review 103, no. 412 (2014/15): 586-97. 
Oliver, George. Collections, Illustrating the History of the Catholic Religion in the Counties of Cornwall, Devon, Dorset, Somerset, Wilts, and Gloucester. London: Charles Dolman, 1857 .

Olson, Richard G. Science and Religion, 1450-19oo: From Copernicus to Darwin. Westport: Greenwood Press, 2004.

O’Malley, John W. "How the First Jesuits Became Involved in Education." In The Jesuit Ratio studiorum: 4ooth Anniversary Perspectives, edited by Vincent J. Duminico, 56-79. New York: Fordham University Press, 2000.

O'Malley, John W. "How Humanistic Is the Jesuit Tradition? From the 1599 Ratio studiorum to Now." In Jesuit Education 21: Conference Proceedings on the Future of Jesuit Higher Education 25-29 June 1999, edited by Martin R. Tripole, 189-201. Philadelphia: St. Joseph's University Press, 2000.

O'Malley, John W. The Jesuits: A History from Ignatius to the Present. Lanham, MD: Rowman \& Littlefield, 2014.

“Oriental Manuscripts, Mainly Hebrew, Collected by Matteo Luigi Canonici.” https:// archiveshub.jisc.ac.uk/search/archives/cefcc137-50e5-3441-b784-adcd718c6f57 (accessed July 29, 2019).

Padberg, John W. Colleges in Controversy: The Jesuit Schools in France from Revival to Suppression (1815-1880). Cambridge, MA: Harvard University Press, 1969.

Pagani, Catherine. "Eastern Magnificence and European Ingenuity": Clocks of Late Imperial China. Ann Arbor: University of Michigan Press, 2001.

Papmehl, K. A. Freedom of Expression in Eighteenth-Century Russia. The Hague: Martinus Nijhoff, 1971.

[Pauli, Andreas Alois di]. "Lebensgeschichte des Landmessers Blasius Hueber: Mit unständlichen Nachrichten von den Arbeiten des Geodeten von Oberperfus." Part 3. Archiv für Geographie, Historie, Staats- und Kriegskunst 7 (1816): 267-72.

Pavone, Sabina. "Banishment, Exile, and Opposition: Jesuit Crises before the 176os." Lusitania sacra 32 (2015): 105-19.

Pavone, Sabina. "The History of Anti-Jesuitism: National and Global Dimensions" In The Jesuits and Globalization: Historical Legacies and Contemporary Challenges, edited by Thomas Banchoff and José Casanova, 111-30. Washington, DC: Georgetown University Press, 2016.

Peck, Anna. "Between Russian Reality and Chinese Dream: The Jesuit Mission in Siberia, 1812-1820." Catholic Historical Review 87, no. 1 (2001): 17-33.

Pelczar, Józef. Zarys dziejów kaznodziejstwa w kościele katolickim. Vol. 2. Kraków: Spółka Wydawnicza Polska, 1896.

Pelzel, Franz Martin. Boehmische, maehrische und schlesische Gelehrte und Schriftsteller aus dem Orden der Jesuiten. Prague: Im Verlag des Verfassers, 1786.

Pitollet, Camille. "Review of Friedrich der Grosse und die Italiener by Alessandro D'Ancona." Bulletin italien 5 (1905): 298-302. 
Poggendorff, Johann Christian. Biographisch-literarisches Handwörterbuch der exakten Naturwissenschaften. 8 Vols. Leipzig: Johann Ambrosius Barth, 1863.

Poole, Stafford. "The New World in Papal Documents: The First Century; Review Article." Catholic Historical Review 78, no. 4 (1992): 601-6.

Porter, Lindsay. "Barruel, Abbé." In Conspiracy Theories in American History: An Encyclopedia; Volume 1, A-L, edited by Phillip DiMare, 115-16. Santa Barbara: ABCCLIO, 2003.

Prieto, Andrés I. "Jesuit Tradition and the Rise of South American Nationalism." InJesuit Survival and Restoration: A Global History, 1773-19oo, edited by Robert A. Maryks and Jonathan Wright, 399-414. Leiden: Brill, 2014.

Printy, Michael. "Catholic Enlightenment and Reform Catholicism in the Holy Roman Empire." In A Companion to the Catholic Enlightenment in Europe, edited by Ulrich L. Lehner and Michael Printy, 165-213. Leiden: Brill, 2010.

Printy, Michael. Enlightenment and the Creation of German Catholicism. Cambridge: Cambridge University Press, 2009.

"Proceedings of the Second Session of the Fifth Parliament of the Kingdom of Great Britain and Ireland." Gentleman's Magazine 115 (1814): 679-82.

Pubitschka, Franz. Ehrenrettung des heiligen Johann von Pomuk oder Nepomuk. Prague: Johann Diesbach, 1791.

Raccolta d'apologie edite, ed inedite della dottrina, e condotta de' PP. Gesuiti in Risposta agli opuscoli che escono contra la Compagnia di Gesù. Venice: Antonio Zatta, 1760-61.

Račkauskas. John A. "The Commission for National Education in Poland and Lithuania (1773-1794): A Historical Study of Some Aspects of Its Educational Reforms." PhD diss., University of Ottawa, 1977.

Raeff, Marc. Michael Speransky: Statesman of Imperial Russia 1772-1839. The Hague: Martinus Nijhoff, 1969 .

Ratio educationis totiusque rei litterariae per Regnum Hungariae. 2 Vols. Vienna: Trattern, 1777 .

Rayez, André. Formes modernes de vie consacrée. Paris: Beauchesne, 1966.

Reff, Daniel T. "Critical Introduction.” In Andrés Pérez de Ribas, History of the Triumphs of Our Holy Faith amongst the Most Barbarous and Fierce Peoples of the New World. Translated by Daniel T. Reff, Maureen Ahern, and Richard K. Danford, 11-45. Tucson: University of Arizona Press, 1999.

Reinhold, Karl Leonard. Essay on a New Theory of the Human Capacity for Representation. Translated by Tim Mehigan and Barry Empson. Berlin: De Gruyter, 2011.

Revuelta González, Manuel. Once calas en la historia de la Compañía de Jesús: "Servir a todos en el Señor". Madrid: Universidad Pontificia Comillas, 2006.

Ricci, Scipione de'. Female Convents: Secrets of Nunneries Disclosed. Edited by Thomas Roscoe. New York: D. Appleton, 1834.

Rice, Louise. "Jesuit Thesis Prints and the Festive Academic Defense at the Collegio Romano." In The Jesuits I: Cultures, Sciences, and the Arts, 1540-1773, edited by 
John W. O'Malley, Gauvin Alexander Bailey, Steven J. Harris, and T. Frank Kennedy, 148-69. Toronto: University of Toronto Press, 1999.

Roehner, Bertrand M. "Jesuits and the State: A Comparative Study of their Expulsions (1590-1990)." Religion 27, no 2 (1997): 165-18.

Romeiras, Francisco Malta. "Jesuit Historiography in Modern Portugal." In Jesuit Historiography Online, edited by Robert A. Maryks. http://referenceworks.brillon line.com/entries/jesuit-historiography-online/jesuit-historiography-in-modernportugal-COM_192570 (accessed July 29, 2019).

Roscoe, Thomas, ed. Memoirs of Scipio de Ricci, Late Bishop of Pistoia and Prato. 2 Vols. London: Henry Colburn, 1829.

Rouët de Journel, Marie Joseph. La Compagnie de Jésus en Russie: Un collège de jésuites à Saint-Pétersbourg, 180o-1816. Paris: Perrin, 1922.

Rowbotham, Arnold H. Missionary and Mandarin: The Jesuits at the Court of China. Berkeley: University of California Press, 1942.

Rudy, Willis. The Universities of Europe, 1100-1914: A History. Rutherford, NJ: Fairleigh Dickinson University Press, 1984.

Ruiu, Adina. "Conflicting Visions of the Jesuit Missions to the Ottoman Empire, 16091628." Journal of Jesuit Studies 1, no. 2 (2014): 260-80.

Rule, William H. Celebrated Jesuits. 2 Vols. London: John Mason, $185^{2-53}$.

Rutkowska, Neomisisa. Bishop Adam Naruszewicz and His History of the Polish Nation: A Critical Study. Washington, DC: Catholic University of America Press, 1941.

Sancta Anna, Joaquim da. Resposta e reflexões a carta que Clemente José Collaço Leitaõ bispo de Cochim escreveo a Salvador Dos Reis arcebispo de Cranganor sobre a sentença [...] contra a herege [...] G. Malagrida. Lisbon: Na Officina de Manoel Soares, 1776.

Sanctissimi in Christo Patris et Domini nostri Domini Pii [...]. Rome: Apud Lazarinum Cameræ Apostolicae Typographum, 1814.

Santich, Jan Joseph. Missio Moscovitica: The Role of the Jesuits in the Westernization of Russia 1582-1689. New York: Peter Lang, 1995.

Saraiva, Luís. "The Jesuit Mathematicians of the Portuguese Assistancy and the Portuguese Historians of Mathematics (1819-1940)." In History of Mathematical Sciences: Portugal and East Asia III; The Jesuits, the Padroado and East Asian Science, 1552-1773, edited by Luís Saraiva and Catherine Jami, 1-31. Singapore: World Scientific Publishing, 2008.

Saranyana, Josep-Ignasi et al. Teología en América Latina. Madrid: Iberoamericana, 2005. Sauer, Werner. "Kant and the Principality of Salzburg." In Detours: Approaches to Immanuel Kant in Vienna, in Austria, and in Eastern Europe, edited by Violetta L. Waibel, 58-73. Vienna: V \& R Unipress, 2015.

Schlafly, Daniel F. "General Suppression, Russian Survival, American Success: The Russian Society of Jesus and the United States." In The Jesuit Suppression in Global Context: Causes, Events, and Consequences, edited by Jeffrey D. Burson and Jonathan Wright, 201-15. Cambridge: Cambridge University Press, 2015. 
Schlafly, Daniel F. "True to the Ratio studiorum? Jesuit Colleges in St. Petersburg." History of Education Quarterly 37, no. 4 (1997): 421-34.

Schmalstieg, William R. "Review of Petras Jonikas, Lietuvių kalba ir tauta amžiu büryje: Visuomeniniai lietuviu kalbos istorijos bruožai (The Lithuanian language and nation through the ages: Outline of a history of Lithuanian in its social context), by Petra Jonikas." Lituanaus 34, no. 4 (1989). http://www.lituanus.org/1989/89_4_o6.htm (accessed July 29, 2019).

Schroth, Raymond. The American Jesuits: A History. New York: New York University Press, 2007.

Schroth, Raymond. "Death and Resurrection: The Suppression of the Jesuits in North America." American Catholic Studies 128, no. 1 (2017): 51-66.

Schwartz, Stuart B. Sugar Plantations in the Formation of Brazilian Society: Bahia, 15501835. Cambridge: Cambridge University Press, 1985.

Schwickerath, Robert. Jesuit Education: Its History and Principles Viewed in the Light of Modern Educational Problems. St. Louis, MO: B. Herder, 1903.

Shank, J. B. [John Bennett]. The Newton Wars and the Beginning of the French Enlightenment. Chicago: University of Chicago Press, 2008.

Shapin, Steven. A Social History of Truth: Civility and Science in Seventeenth-Century England. Chicago: University of Chicago Press, 1994.

Shea, John Gilmary. Catholic Missions: Among the Indian Tribes of the U.S. 1529-1854. New York: P. J. Kenedy \& Sons, 1854.

Shea, John Gilmary. Memorial of the First Century of Georgetown College, D.C. Washington, DC: P. F. Collier, 1891.

Shore, Paul. The Eagle and the Cross: Jesuits in Late Baroque Prague. Saint Louis, MO: Institute of Jesuit Sources, 2002.

Shore, Paul. "Enduring the Deluge: Hungarian Jesuit Astronomers from Suppression to Restoration." In Jesuit Survival and Restoration: A Global History, 1773-19oo, edited by Robert A. Maryks and Jonathan Wright, 148-61. Leiden: Brill, 2014.

Shore, Paul. "Ex-Jesuits in the East Habsburg Lands, Silesia and Poland." In The Jesuit Suppression in Global Context: Causes, Events, and Consequences, edited by Jeffrey D. Burson and Jonathan Wright, 229-47. Cambridge: Cambridge University Press, 2015.

Shore, Paul. Jesuits and the Politics of Religious Pluralism in Eighteenth-Century Transylvania. Aldershot and Rome: Ashgate and Institutum Historicum Societatis Iesu, 2007.

Shore, Paul. Narratives of Adversity: Jesuits in the Eastern Peripheries of the Habsburg Realms (1640-1773). Budapest: CEU Press, 2012.

Shore, Paul. "The Suppression of the Society of Jesus in Bohemia." Archivum historicum Societatis Iesu 65 (1996): 138-56. 
Shore, Paul. "Universalism, Rationalism and the Jesuits of Bohemia 1770-180o." In Progrès et violence au XVIIe siècle, edited by Valérie Cossy and Deidre Dawson, 7183. Paris: Honoré Champion, 2001.

Shore, Paul, and Maurice Whitehead. "Crisis and Survival on the Peripheries: Jesuit Culture, Continuity and Change at Opposite Ends of Continental Europe, 17621814." History of Universities 4 (2010): 173-205.

Signorelli, Bruno. "Le gesuiti sabaudi durante la soppressione (1773-1814)." In Morte e resurrezione di un ordine religioso: Le strategie culturali ed educative della Compagnia di Gesú durante la soppressione (1759-1814), edited by Paolo Bianchini, 109-31. Milan: Vita e Pensiero, 2006.

Simon, Constantin. "The 19th-Century Volga Mission of the Society of Jesus." Archivum historicum Societatis Iesu 62 (1993): 43-86.

Simmons, Merle Edwin. Los escritos de Juan Pablo Viscardo y Guzmán, precursor de la independencia Hispanoamericana. Caracas: Universidad Católica Andrés Bello, 1983.

Smith, Jeffrey Chipps. “The Jesuit Artistic Diaspora in Germany after 1773." In Jesuit Survival and Restoration: A Global History, 1773-19oo, edited by Robert A. Maryks and Jonathan Wright, 129-47. Leiden: Brill, 2014.

Smith, Marie-Antoinette, ed. Thomas Clarkson and Ottobah Cugoano: Essays on the Slavery and Commerce of the Human Species. Peterborough, ON: Broadview Editions, 2010.

Smith, Stefan Halikowski. Creolization and Diaspora in the Portuguese Indies: The Social World of Ayutthaya, 1640-1720. Leiden: Brill, 2011.

Smith, Sydney. The Suppression of the Society of Jesus. Edited by Joseph A. Munitiz. Leominster: Gracewing, 2004.

Sommervogel, Carlos, ed. Bibliothèque de la Compagnie de Jésus: Nouvelle édition. 11 Vols. Brussels and Paris: Oscar Schepens and A. Picard, 1890-1930.

Stoeger, Johann Nepomuk. Scriptores provinciae Austriacae Societatis Jesu ab ejus origine ad nostra usque tempora. Vienna: Typis Congr. Mechit., 1856.

Stolarski, Piotr. Friars on the Frontier: Catholic Renewal and the Dominican Order in Southeastern Poland 1594-1648. Abingdon: Routledge, 2016.

Stone, Daniel. The Polish-Lithuanian State, 1386-1795. Seattle: University of Washington Press, 2001.

Storrs, Christopher. "The Suppression of the Jesuits in the Savoyard State." In The Jesuit Suppression in Global Context: Causes, Events, and Consequences, edited by Jeffrey D. Burson and Jonathan Wright, 138-6o. Cambridge: Cambridge University Press, 2015.

Sullivan, Michael. The Meeting of Eastern and Western Art. Berkeley: University of California Press, 1989. 
Swann, Julian. Provincial Power and Absolute Monarchy: The Estates General of Burgundy 1661-179o. Cambridge: Cambridge University Press, 2003.

Szabo, Francis A. J. Kaunitz and Enlightened Absolutism 1753-1780. Cambridge: Cambridge University Press, 1994.

Szászdi, Adam. "The Historiography of the Republic of Ecuador." Hispanic American Historical Review 44, no. 4 (1964): 503-50.

Szegedy-Maszák Mihály et al. A magyar irodalom történetei: A kezdetektől 180o-ig. Budapest: Gondolat Kiadó, 2007.

Szent-Mártony, Ignácz. Einleitung zur kroatischen Sprachlehre für Teutsche. [Varaždin]: [1783].

Szilas, László. “Paintner Mihály Antal.” In Diccionario histórico de la Compañía de Jesús, edited by Charles E. O’Neill and Joaquín María Domínguez, 3:2948. 4 Vols. Rome and Madrid: Institutum Historicum S.I. and Universidad Pontificia Comillas, 2001.

Tang, Kaijian. Setting Off from Macau: Essays on Jesuit History during the Ming and Qing Dynasties. Leiden: Brill, 2015.

Tardieu, Pierre. "Los esclavos de los jesuitas del Perú en la época de la expulsión (1767)." Caravelle 81 (2003): 61-109.

Terwecoren, Édouard. Esquisse historique sur le T. R. P. Roothaan, XXIe général de la Compagnie de Jésus. 3rd ed. Brussels: Vandereydt, 1857.

Thompson, D. G. [Gillian] "The LaVallette Affair and the Jesuit Superiors." French History 10, no. 2 (1996): 206-39.

"Three Works on Ossian." British Critic, and Quarterly Theological Review 33 (1809): 163-80.

Till, Nicholas. Mozart and the Enlightenment. London: Faber \& Faber, 1992.

[Toderini, Giambattista]. Compendio storico di memorie cronologiche concernenti la religione e la morale della nazione armena suddita dell'Impero ottomano, opera divisa in sei libri [...] dal marchese Giovanni de Serpos. Venice: Stamp. di C. Palese, 1786.

[Toderini, Giambattista]. Letteratura turchesca, dell'abate Giambatista [sic] Toderini [...]. Venice: G. Storti, 1787 .

Toderini, Giambattista, and Domenico Troili. Dissertazione sopra un legno fossile. Modena: Nella Stamperia di Giovanni Montanari, 1770.

Tolrá, Juan José.Justificación histórico-crítica de la venida del apóstol Santiago el Mayor á España. Madrid: Impr. de la viuda de Ibarra, 1797.

Tolrá, Juan José. Reclamación de tres ex-jesuitas españoles residentes en la península. Vic: En la oficina de Juan Dorca; Á expensas de algunos apasionados á los ex-jesuitas.

Topij-Stempińska, Beata. "Jezuici i Komisja Edukacji Narodowej w polskiej historiografii XX wieku i początkach XXI wieku." Biblioteka wspótczesnej myśli pedagogicznej 3 (2014): 409-18.

Trautmann, Thomas R. Aryans and British India. London: Yoda Press, 2004. 
Treadgold, Donald W. The West in Russia and China: Russia, 1472-1917. Cambridge: Cambridge University Press, 1973.

Udías, Agustín. "Jesuits' Studies of Earthquakes and Seismological Stations." In Geology and Religion: A History of Harmony and Hostility (Geological Society London Special Publications 310, no. 1), edited by Martina Kölbl-Ebert, 135-43. London: Geological Society, 2009.

Udías, Agustín. Searching the Heavens and the Earth: The History of Jesuit Observatories. Dordrecht: Kluwer, 2003.

Universidade de Coimbra. Compendio historico do estado da Universidade de Coimbra no tempo da invasão dos denominados jesuitas e dos estragos feitos nas sciencias e nos professores, e directores que a regiam pelas maquinações, e publicações dos novos estatutos por elles fabricados. Lisbon: Na Regia Officina Typografica, 1772.

Valencia Caicedo, Felipe. "The Mission: Human Capital Transmission, Economic Persistence, and Culture in South America." Quarterly Journal of Economics 134, no. 1 (2019): 507-56.

Van Horn, James Melton. Absolutism and the Eighteenth-Century Origins of Compulsory Schooling in Prussia and Austria. Cambridge: Cambridge University Press, 1988.

Van Kley, Dale. "Catholic Conciliar Reform in an Age of Anti-Catholic Revolution." In Religious Differences in France: Past and Present, edited by Kathleen P. Long, 91-140. Kirksville, MO: Truman State University Press, 2006.

Van Kley, Dale. "Jansenism and the International Suppression of the Jesuits." In The Cambridge History of Christianity, vol. 7, Enlightenment, Awakening, and Revolution, edited by Stuart Brown and Timothy Tackett, 302-28. Cambridge: Cambridge University Press, 2006.

Van Kley, Dale. The Jansenists and the Expulsion of the Jesuits from France, 1757-1765. New Haven: Yale University Press, 1975.

Van Kley, Dale. "Plots and Rumors of Plots." In The Jesuit Suppression in Global Context: Causes, Events, and Consequences, edited by Jeffrey D. Burson and Jonathan Wright, 13-39. Cambridge: Cambridge University Press, 2015.

Van Kley, Dale. Reform Catholicism and the International Suppression of the Jesuits in Enlightenment Europe. New Haven: Yale University Press, 2018.

Varley, Paul.Japanese Culture. 4th ed. Honolulu: University of Hawai'i Press, 2000.

Vélez, Karin. "Jesuits: Expulsion." In Iberia and the Americas: Culture, Politics, and History, edited by John Michael Francis, 1:607-10. Santa Barbara: ABC-CLIO, 2006.

Venturi, Franco. The End of the Old Regime in Europe, 1776-1789, Part I: The Great States of the West. Translated by Robert Burr Litchfield. Princeton: Princeton University Press, 1991.

Vermote, Fred. "Finances of the Missions." In A Companion to Early Modern Catholic Global Missions, edited by Ronnie Po-chia Hsia, 367-40o. Leiden: Brill, 2018. 
Viansson-Ponté, Louis. Les jésuites à Metz: Collège Saint-Louis, 1622-1762, Collège Saint Clément, 1852-1872. Strasbourg: F. X. Le Roux, 1897.

Villalba Pérez, Enrique. Consecuencias educativas de la expulsión de los jesuitas de América. Madrid: Editorial Dykinson, 2003.

"Viri illustres Societatis Jesu." Woodstock Letters 27, no. 1 (1898): 42-46.

De vita et scriptis Bernardi Zamagnae patricii Rhacusini commentariolum [...] Francisci Mariae Appendini. Biograd na Moru: Typis Joannis Demarchi, 1830.

Von Mende, Erling. "Problems in Translating the Bible into Manchu: Observations on Louis Poirot's Old Testament." In Sowing the Word: The Cultural Impact of the British and Foreign Bible Society 1804-2004, edited by Stephen K. Batalden, Kathleen Cann, and John Dean, 149-68. Sheffield: Sheffield Phoenix Press, 2004.

Von Murr, Christoph Gottlieb, ed. Reisen einiger Missionarien der Gesellschaft Jesu in Amerika. Nuremberg: Johann Eberhard Zeh, 1785 .

Von Ranke, Leopold. The Ecclesiastical and Political History of the Popes of Rome: During the Sixteenth and Seventeenth Centuries. Translated by Sarah Austin. 2nd ed. 3 Vols. London: John Murray, 1841.

Von Wurzbach, Constant. Biographisches Lexikon des Kaiserthums Oesterreich. 61 Vols. Vienna: Various Imprints, $1856-91$.

Waley-Cohen, Joanna. "China and Western Technology in the Late Eighteenth Century." American Historical Review 98, no. 5 (1993): 1525-44.

Waddell, Mark A. "Encyclopedias." In The Cambridge Encyclopedia of the Jesuits, edited by Thomas Worcester, 282-83. Cambridge: Cambridge University Press, 2017.

Waddell, Mark A. Jesuit Science and the End of Nature's Secrets. New York: Routledge, 2016.

Walker, Charles F. The Tupac Amaru Rebellion. Cambridge, MA: Harvard University Press, 2014.

Walsh, Michael. A New Dictionary of Saints: East and West. Collegeville, MN: Liturgical Press, 2007.

Wehner, Richard. Jesuiten im Norden. Paderborn: Bonifatius-Druckerei, 1974.

[Wernz, Franz Xaver, and Ludwig Schmitt]. Synopsis historice SocietatisJesu. Regensburg: Typis Frederici Pustet, 1914.

Whitehead, Maurice. English Jesuit Education: Expulsion, Suppression, Survival, and Restoration. London: Routledge, 2013.

Witte, Leopold. Friedrich der Große und die Jesuiten. Naumburg: Sieling, 1892.

Wolff, Larry. "The Spirit of 1776: Polish and Dalmatian Declarations of Philosophical Independence." In History of the Literary Cultures of East-Central Europe: Junctures and Disjunctures in the 19th and 2oth Centuries, edited by Marcel Cornis-Pope and John Neubauer, 1:294-306. Amsterdam: John Benjamins, 2004. 
Worcester, Thomas. "Pius VII: Moderation in an Age of Revolution and Reaction." In The Papacy since 1500: From Italian Prince to Universal Pastor, edited by James Corkery and Thomas Worcester, 107-24. Cambridge: Cambridge University Press, 2010.

Woźniak, Andrzej. "Kultura ludowa Gruzji w relacjach polskich do początków XX w." Etnografia Polska 27, no. 1 (1983): 297-320.

Wright, Jonathan. "From Immolation to Restoration: The Jesuits, 1773-1814." Theological Studies 75, no. 4 (2014): 729-45.

Wright, Jonathan. "Pombal, Marquis." In The Cambridge Encyclopedia of the Jesuits, edited by Thomas Worcester, 627-28. Cambridge: Cambridge University Press, 2017.

Young, John D. Confucianism and Christianity: The First Encounter. Hong Kong: Hong Kong University Press, 1983 .

Załenski, Stanislas. Les jésuites de la Russie-Blanche. 2 Vols. Translated by Alexandre Vivier. Paris: Letouzey et Ané, [1886?].

Zambrano, Francisco, and José Gutiérrez Casillas. Diccionario bio-bibliográfico de la Compañía de Jesús en México. 16 Vols. Mexico City: Editorial Jus, 1961-77.

Zanconato, Alessandro. La dispute du fatalisme en France: 1730-176o. Fasano: Schena Editore, 2004. 